\title{
The hydromedusae and water masses of the Indian Ocean
}

\author{
Denise NAVAS-PEREIRA ${ }^{1}$ \& Marta VANNUCCI ${ }^{2}$
}

\author{
1 - Divisāo de Análises Hidrobiológicas - CETESB \\ (Av. Professor Frederico Hermann Jr., 345 - CEP 05489, São Paulo, SP) \\ 2 - Present address: Rua Flórida, 1133 - apto. 84 \\ (CEP 04565, São Paulo, SP)
}

\begin{abstract}
- Abstract: This analysis of distribution and abundance of species of Hydromedusae completes a report (Vannucci \& Navas, 1973b) on the ecology of Indian Ocean Hydromedusae based on the zooplankton collected during the International Indian Ocean Expedition (IIOE). Distribution and abundance are taken here to be the ecological expression of variability of species in space and time. The aim was to identify the biological signature of below surface water masses that cannot be identified by remote sensing techniques. Selected species were taken as biological units, the oceanic water masses as defined by their T-S and T- $\mathrm{O}_{2}$ diagrammes were taken as the non biological units. Taken together they define different ecosystems of the Indian Ocean. About 45,000 specimens of hydromedusae taken at 480 stations were sorted from 900 plankton samples and all specimens were determined and counted. Several hauls, mostly stratified, were taken with closing nets, but not all contained hydromedusae. The distribution of each species was studied in relation to water salinity, temperature and dissolved oxygen; the limits of ecological tolerance and preference were defined by the environmental characteristics of the layers sampled by the nets and are given for each species. These can be grouped as follows: 1 . Deep water species, cold tolerant, often eurytopic; 2 . Antarctic species, cold loving, usually stenothermal with preference for low salinity; 3 . Indian Ocean Central Water species, with preference for temperature lower than $19^{\circ} \mathrm{C}$ and salinity not much higher than $35 \%$, usually found at sub-surface or intermediate depths, they may spread into the Arabian Sea and Bay of Bengal in surface layers; 4. Indian Ocean Equatorial System species, warm tolerant, usually prefer comparatively low salinity, high temperature and high oxygen content; 5. Bay of Bengal Surface Water species, found in surface layers of the Bay, with preference for low salinity, high temperature and high oxygen content; 6 . Arabian Sea Surface Water species prefer very high salinity and high temperature; 7. Rare species. Some immigrants from the Mediterranean Sea are described and many species were found to be tolerant of dissolved oxygen content as low as $0.2 \mathrm{ml} / 1$. Numerous individuals of many species were found to agglomerate at boundary layers.
\end{abstract}

- Descriptors: Hydromedusae; Ecological distribution; Water masses; Indian Ocean.

- Descritores: Hydromedusas; Distribuiçāo ecológica; Massas d'água; Oceano Indico.

\section{Introduction}

Some of the biological and physical characteristics of the surface layers of oceanic and coastal waters can be detected by remote sensing techniques. The characteristics of deeper layers however cannot be defined by the same techniques and the recognition of structure and dynamics of deeper layers still relies on sampling and data taking instruments, many of them of a recording type. The purpose of this paper is to recognize the biological signature of water masses, in turn this will contribute to the understanding of the structure and dynamics of oceanic systems and oceanic circulation. For the purpose of decoding the data and samples at hand we used the T-S 
diagramme as the basic representation of the non-living environment and we took the species as the basic biologic unit. To achieve the aim we required a large amount of data and samples taken over an extensive area, preferably a whole ocean, during a relatively long period of time and at different seasons. We chose to work with the extensive collections obtained during the International Indian Ocean Expedition (IIOE) and with Hydromedusae as biologic units. We selected the latter because we were familiar with the taxonomy, because we could work at the same time with holo- and meroplanktonic species and because we had earlier done similar work though of lesser magnitude. Meroplanktonic species of hydromedusae have a bottom-living attached hydropolyp in their life cycle and thus are dependent on the continental or insular shelves or on hard floating substrates, including ship hulls, to complete the cycles.

The identification of the biological signature of water masses is useful for the study of primary productivity and dispersal of polluting agents as well as for the study of pollution control and spread of polluting agents into deep waters and over the ocean bottom; these studies are useful also for the planning of waste disposal. The information acquired helps in understanding the general circulation of the deep layers of the oceans and may help for the assessment of the time involved in the displacement of water masses.

Volumetrically and gravimetrically the hydromedusae are not among the major constituents of the zooplankton, indeed only a small fraction of the living matter and energy of the oceanic trophic web is bound as small jellyfishes. Hydromedusae however represent an important category, because of their ecological significance as exclusive carnivores, because of their frequent presence and wide geographic and bathymetric distribution and finally because they may form localized aggregates or dense swarms. Taxonomically the hydromedusae are in good order, mainly due to the work done by W. J. Rees (British Museum), by F. S. Russell (Marine Biological Association of the United Kingdom) and by P. L. Kramp (Zoological Museum of the University of Copenhagen). The wealth of plankton material collected during the International Indian Ocean Expedition (IIOE) affords a good opportunity to study the patterns of distribution of the medusae of the Indian Ocean. The sampling design at sea and the cruise tracks were dictated mainly by what was known or suspected at the time, of phenomena of particular oceanographic interest, such as the monsoonal cycles, areas of upwelling, equatorial surface and sub-surface systems and general structure and dynamics of the Indian Ocean. Plankton sampling was unavoidably biased because of these constraints but the use of closing nets and the large number of samples taken synoptically with environmental data of conservative and non-conservative parameters, gives to the IIOE collection of zooplankton samples an unrivaled value for the study of natural large scale oceanic ecosystems.

About 45,000 specimens of hydromedusae were taken, synoptic environmental data are available for almost all the stations and closing nets were used regularly; this combination of factors enabled us to make an ecological interpretation of the distribution and abundance of the hydromedusae of the Indian Ocean in an earlier Report to UNESCO (Vannucci \& Navas, 1973b).

Navas (1971) reported on the distribution and abundance of new records for the Indian Ocean; Vannucci \& Navas (1973a) discussed the results of the first analyses of distribution and abundance of selected species; this enabled us to establish a methodology and showed that water masses, boundary layers and major geographic areas have different associations of species and have a characteristic fauna of hydromedusae. Vannucci \& Navas (1973b) described details of the ecological valence of each species taken during the $\mathrm{IOE}$ as well as immigrants into the Indian Ocean.

This paper gives the patterns of distribution as determined by environmental factors, mainly salinity, temperature, dissolved oxygen content, transport by water masses, major currents and food availability.

\section{Material and methods}

Station list and details of the material studied are given in Navas (1971) and Vannucci \& Navas (1973a). The collection studied was given on loan by the Smithsonian Institution (Washington, D.C., U.S.A.) to the Oceanographic Institute of the University of São Paulo (Brazil) and comprises of about 45,000 specimens that were sorted from more than 900 samples taken by the R.V. "Anton Bruun" during the IIOE; plankton samples were taken at 480 stations and more than one haul was made at each station, at different depth intervals with closing nets or with different nets to the surface. Each haul received a different sample number. Hydromedusae were present at 321 stations or about $67 \%$ of the total number of stations. Different types of nets and different mesh sizes were used at sea, details are given in the papers mentioned above.

The following procedure was used for the analyses: 1 . the list of stations was prepared with environmental data (stations without hydrographic data were disregarded); 2. the autoecology of each species was assessed as far as possible; 3 . vertical and horizontal distribution and distribution in relation to water masses and general circulation were assessed; 4 . attempts to analyse causes of numerical abundance were made. Figure 1 gives oxygen, temperature and salinity profiles of selected stations positive for the more representative species whose number and depth distribution is also given. Figures 2-16 are examples of the large number of graphs made to visualize the distribution and abundance and relations of cause and effect. The list of species is given in Vannucci \& Navas (1973b, p. 2-6); geographic distribution (coordinates only) is given in Vannucci \& Navas (1973b, maps, p. 38-48).

Hydrographical data are given in the Station Lists of the Cruise Reports published by Woods Hole Oceanographic Institute (Anon., 1963-1965). 


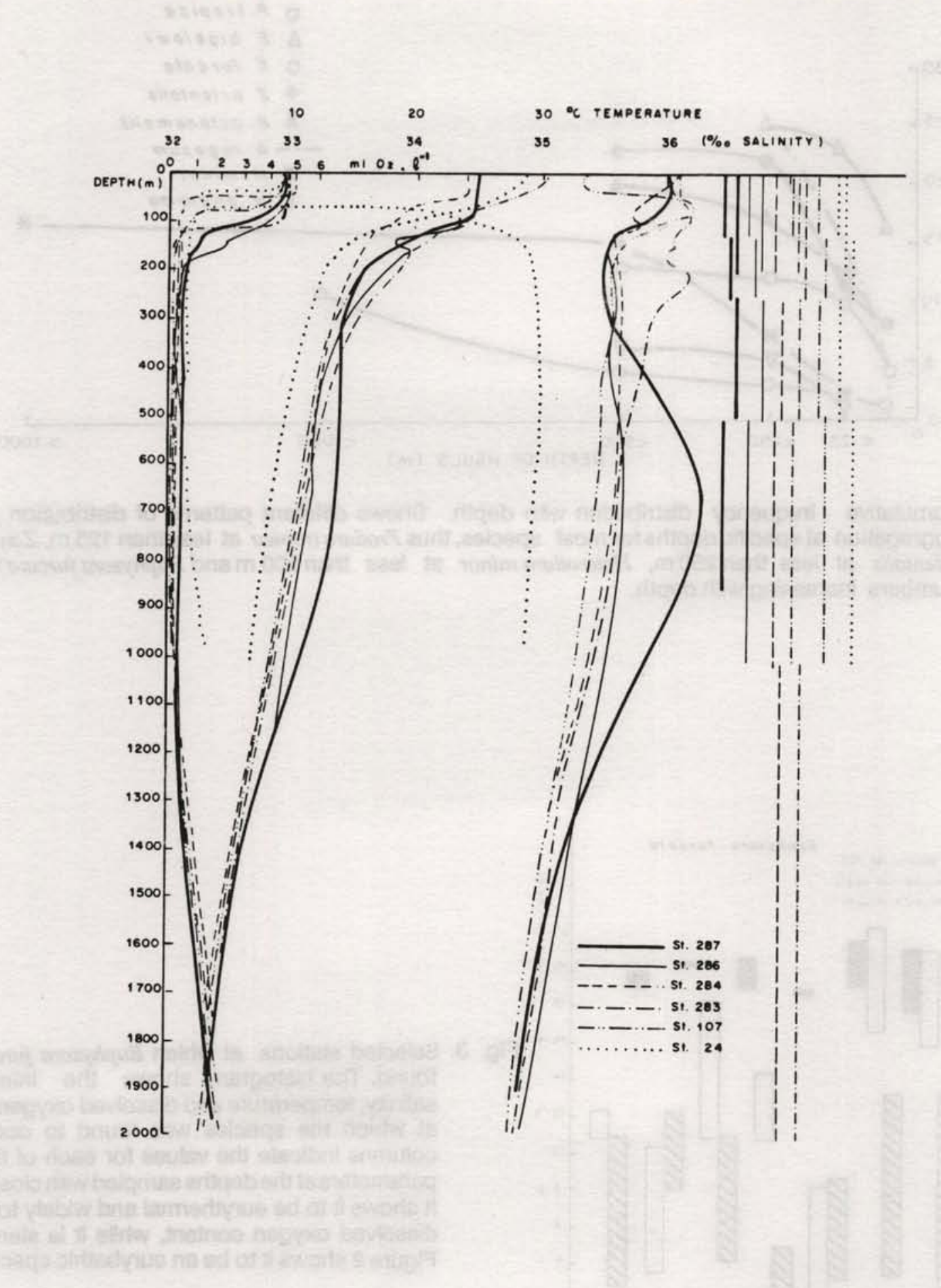

Fig. 1. Oxygen, temperature and salinity profiles of selected stations that were positive for the species studied. On the right hand side, station number, indicating depth of haul and presence or absence of the species. Thus, for example, St. 24 had the following catch:

125-0 m: Zancleopsis tentaculata (1), Cytaeis tetrastyla (3), Aglaura hemistoma (18), Cunina frugifera (1), Cunina octonaria (1), C. peregrina (1), Solmundella bitentaculata (3).

200-0m: A. hemistoma (4), Liriope tetraphylla (1), Rhopalonema velatum (3), C. peregrina (1).

250-125 m: Euphysilla pyramidata (1), Vannuccia forbesi (1), Koellikerina octonemalis (1), A. hemistoma (1), L. tetraphylla (12), R. velatum (7), Sminthea eurygaster (2), C. octonaria (2), C. peregrina (1), C. tenella (1), Pegantha triloba (1), S. bitentaculata (2).

500-250 m: Heterotiara anonyma (1), Obelia $\quad$ spp. (1), L. tetraphylla (1), Persa incolorata (1), R. velatum (1), C. peregrina (2), S. bitentaculata (4). 


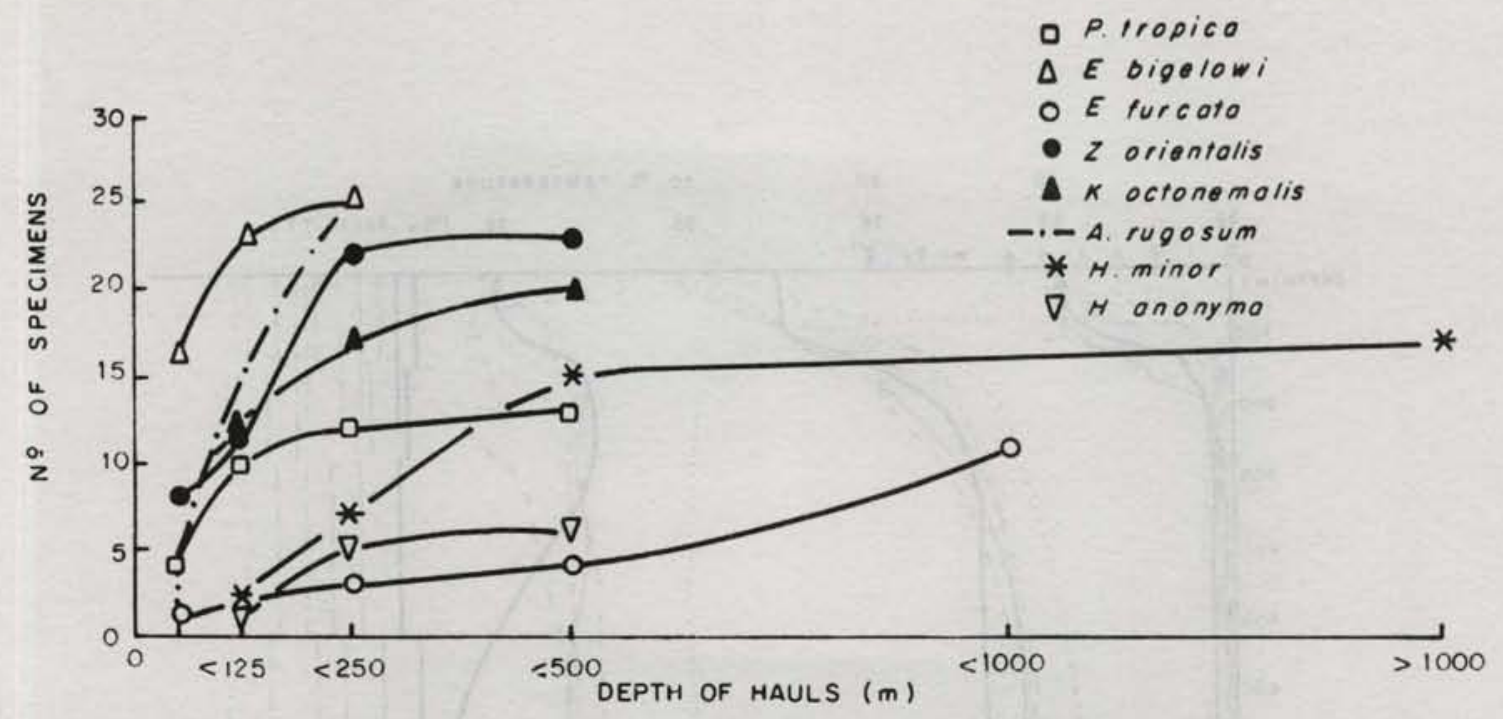

Fig. 2. Cumulative frequency distribution with depth. Shows different patterns of distribution and aggregation at specific depths for most species, thus Protiara tropica at less than $125 \mathrm{~m}$, Zanclea orientalis at less than $250 \mathrm{~m}$, Heterotiara minor at less than $500 \mathrm{~m}$ and Euphysora furcata with numbers increasing with depth.

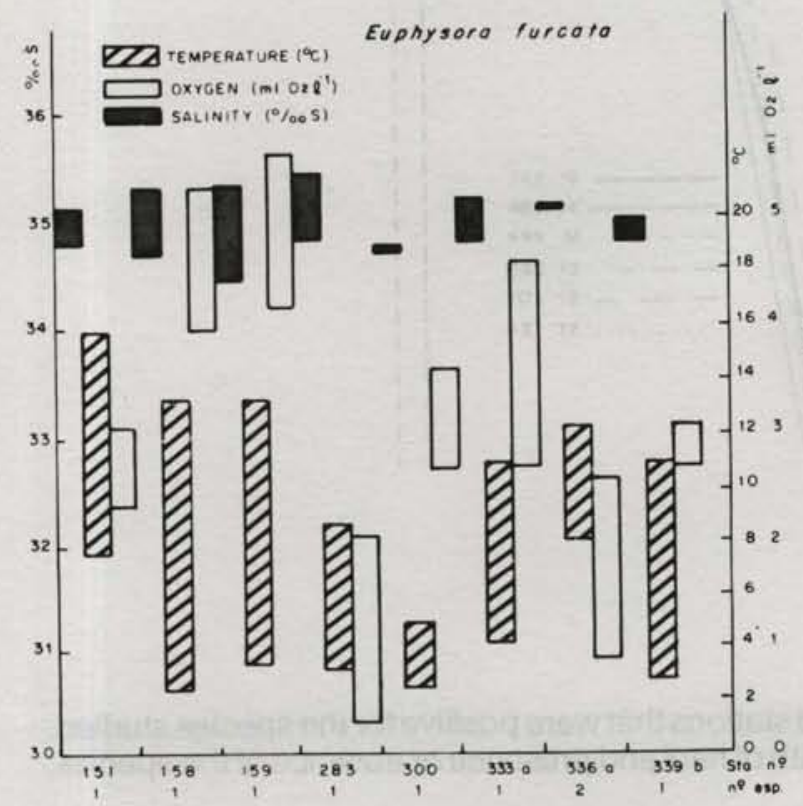

Fig. 3. Selected stations at which Euphysora furcata was found. The histogram shows the intervals of salinity, temperature and dissolved oxygen content at which the species was found to occur. The columns indicate the values for each of the three parameters at the depths sampled with closing nets. It shows it to be eurythermal and widely tolerant of dissolved oxygen content, while it is stenohaline. Figure 2 shows it to be an eurybathic species. 


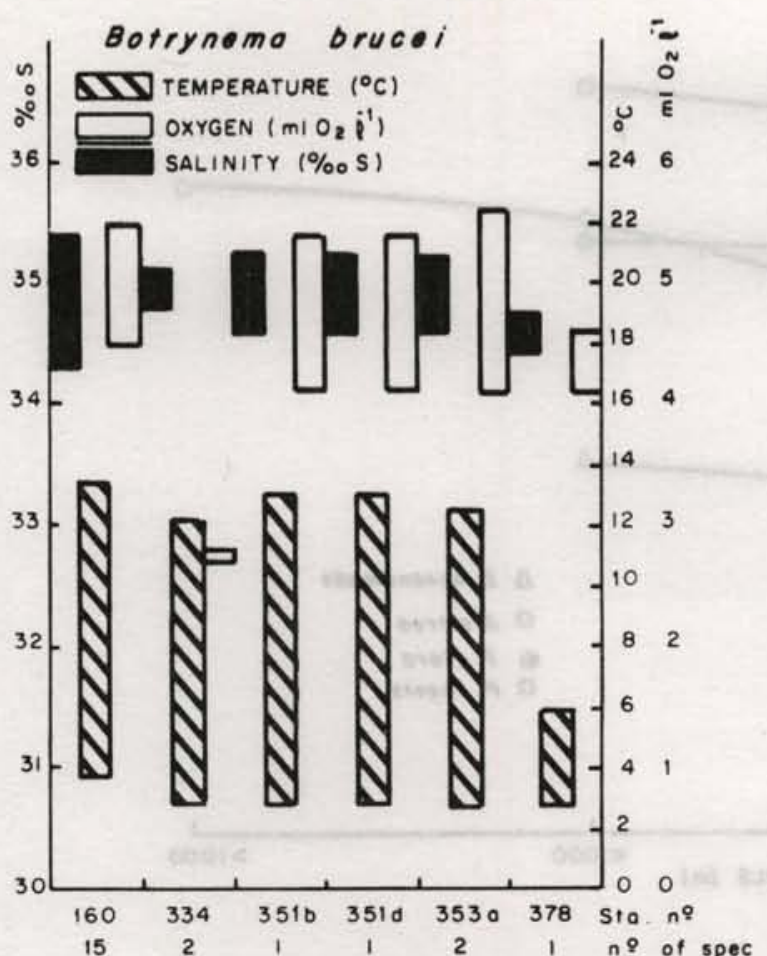

Fig. 4. Selected stations at which Botrynema brucei was found; shows it to be a cold water species, stenotopic for salinity, temperature and dissolved oxygen content. Figure 5 shows it to be an intermediate layer species.

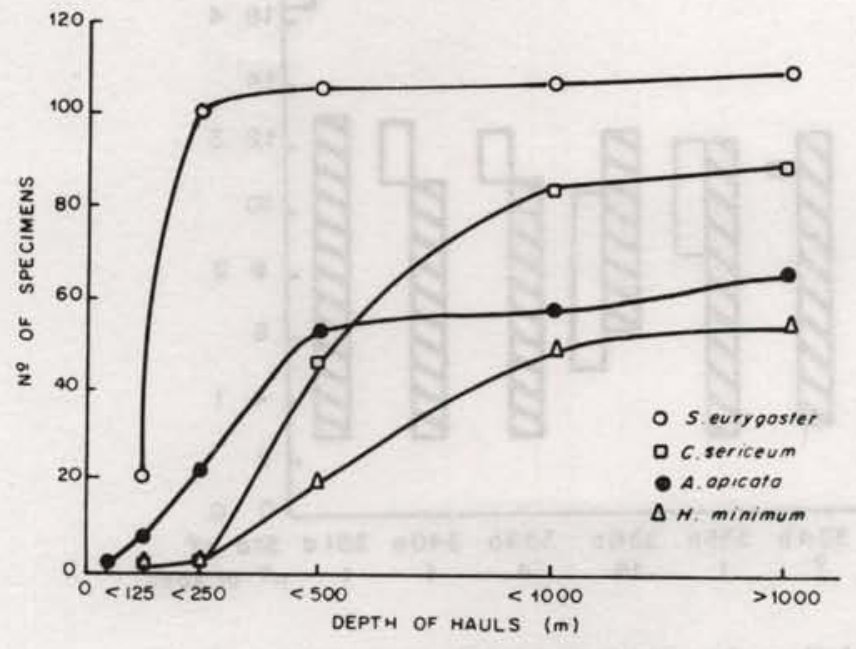

Fig. 6. Cumulative frequency distribution with depth. Surface (Sminthea eurygaster) and deep water species.

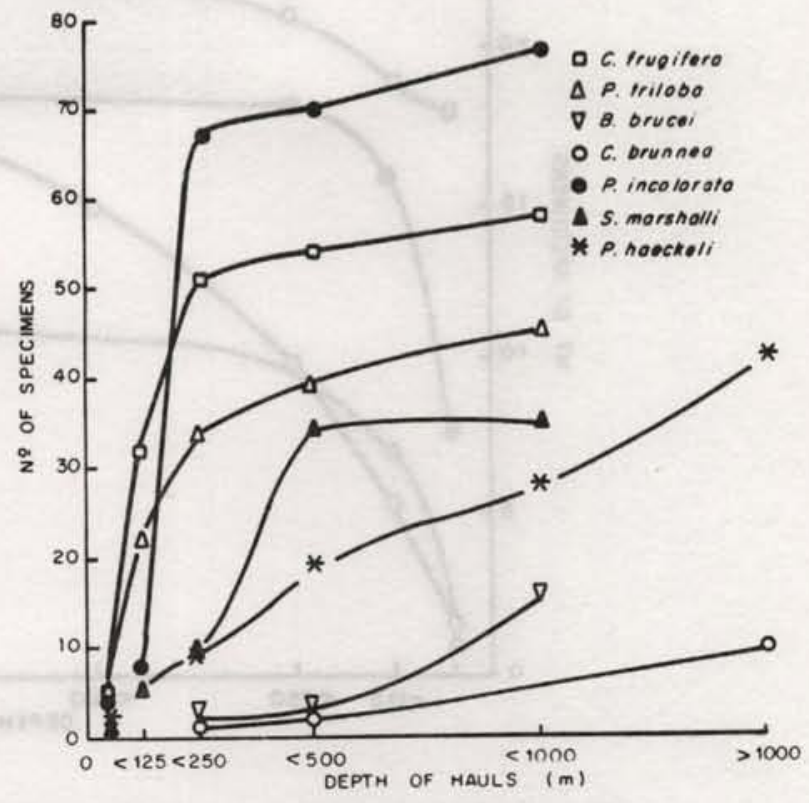

Fig. 5. Cumulative frequency distribution with depth; shows well marked aggregation of the many species at certain depths, thus Persa incolorata between 125 and $250 \mathrm{~m}$ and Solmissus marshalli at $500 \mathrm{~m}$ (or less).

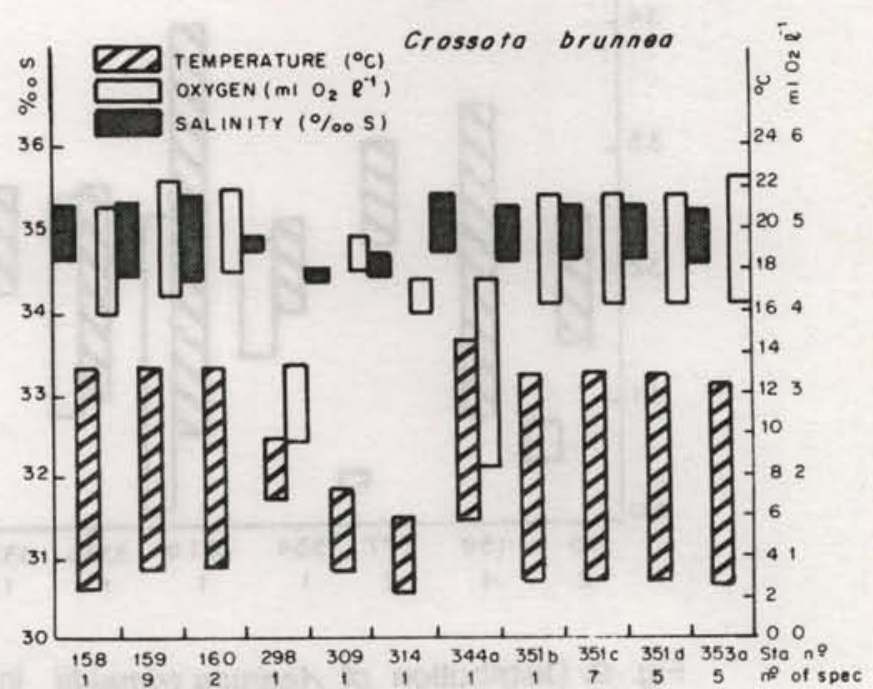

Fig. 7. Selected stations at which Crossota brunnea was taken. It shows it to be stenohaline with high oxygen requirements. An intermediate water species, eurybathic; see Figure 5. 


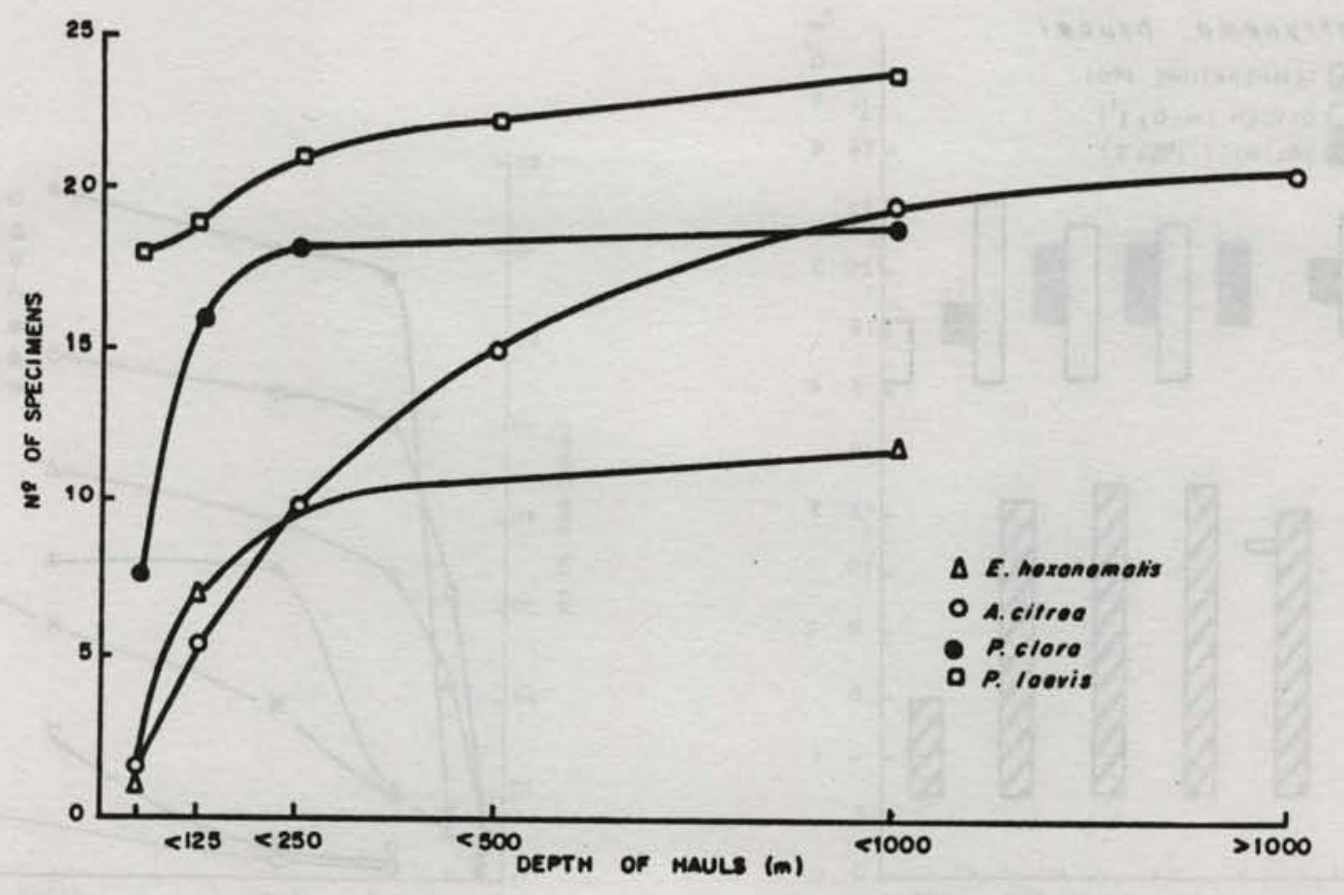

Fig. 8. Cumulative frequency distribution with depth. Aegina citrea and eurybathic species.

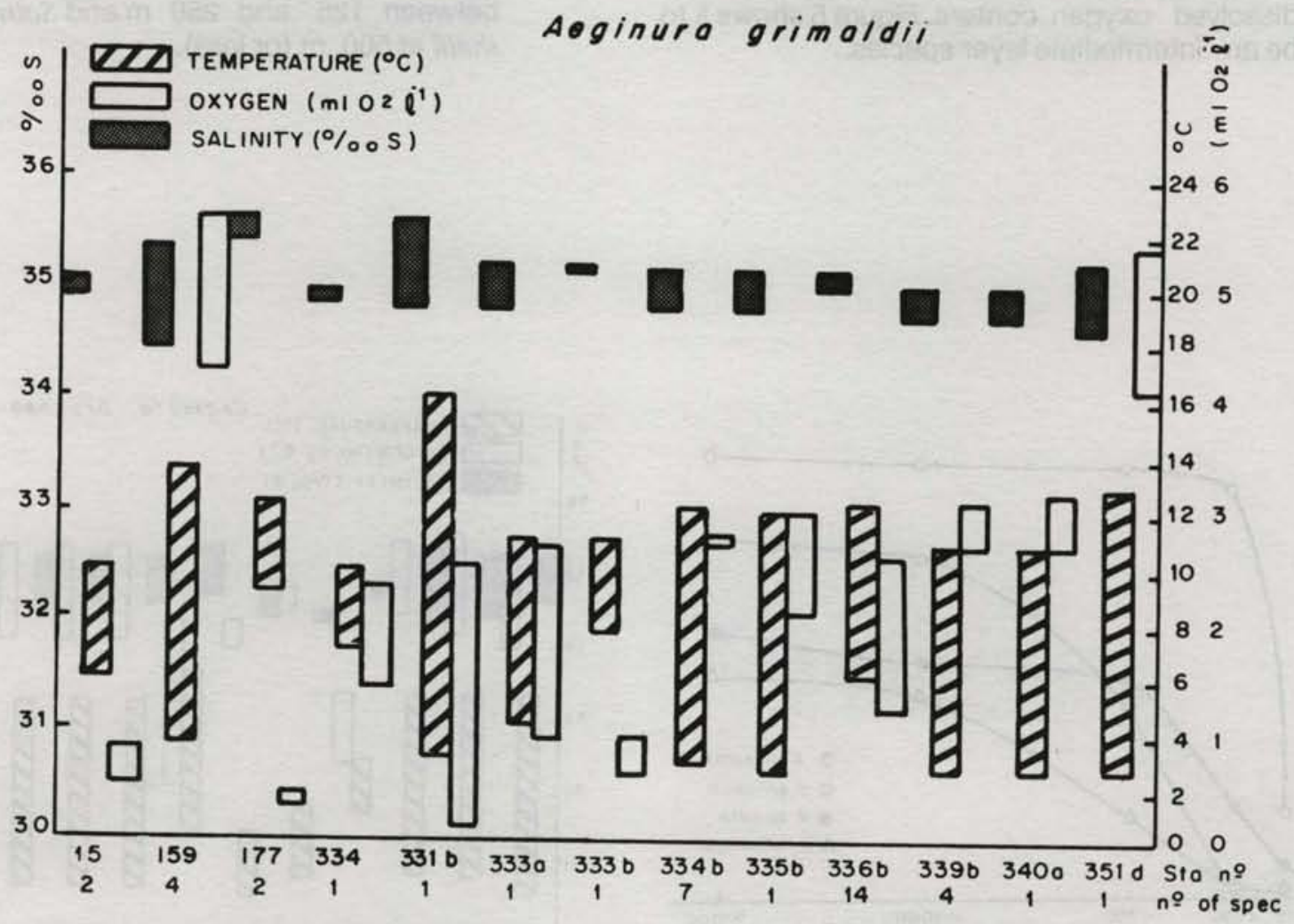

Fig. 9. Distribution of Aeginura grimaldii in relation to environmental parameters; it is stenohaline, rather eurythermal and tolerant of varied dissolved oxygen content. 


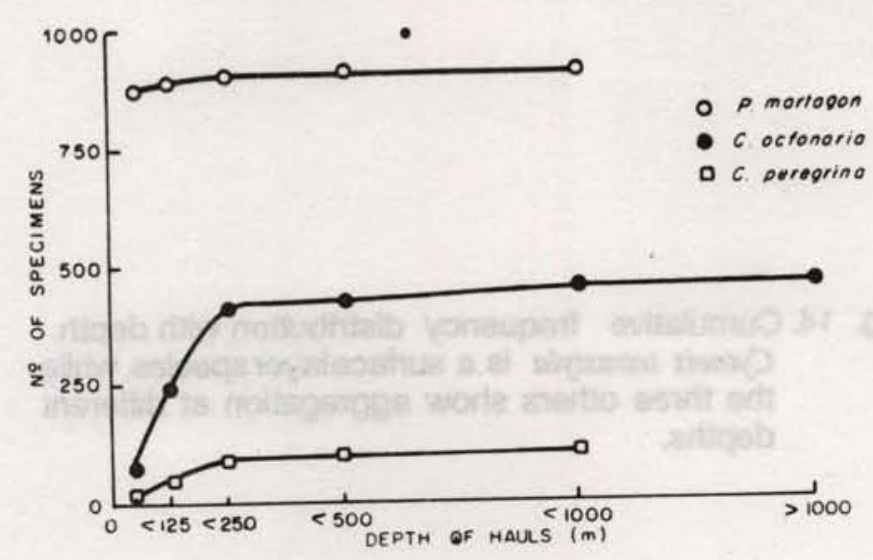

Fig. 10. Cumulative frequency distribution with depth. Pegantha martagon a surface layer species, as well as Cunina peregrina, the latter however shows some aggregation at $250 \mathrm{~m}$ depth or less.

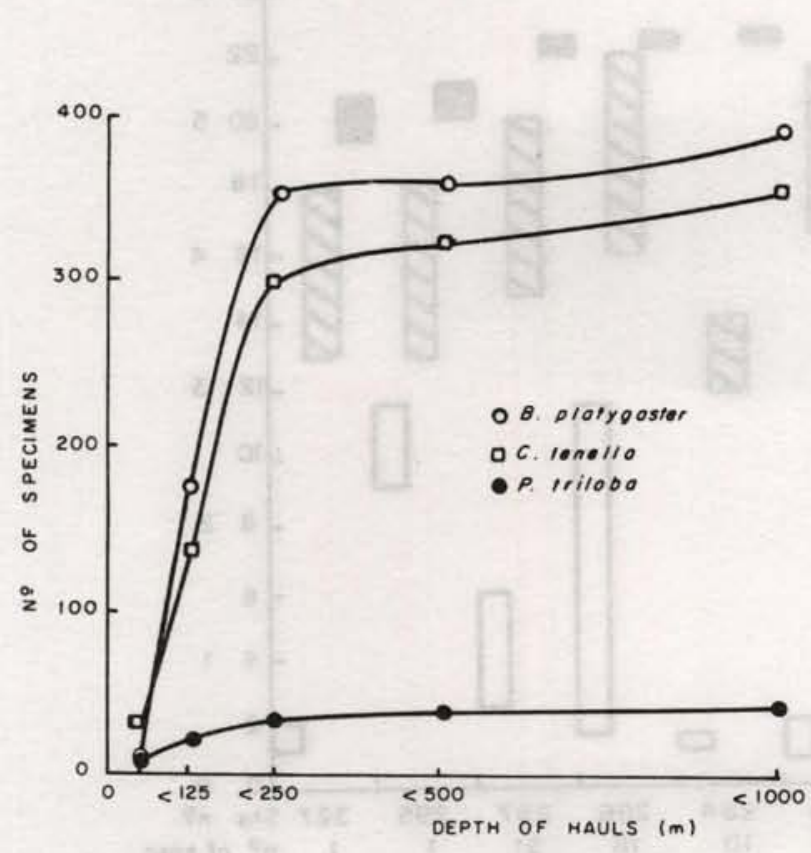

Fig. 12. Cumulative frequency distribution with depth.

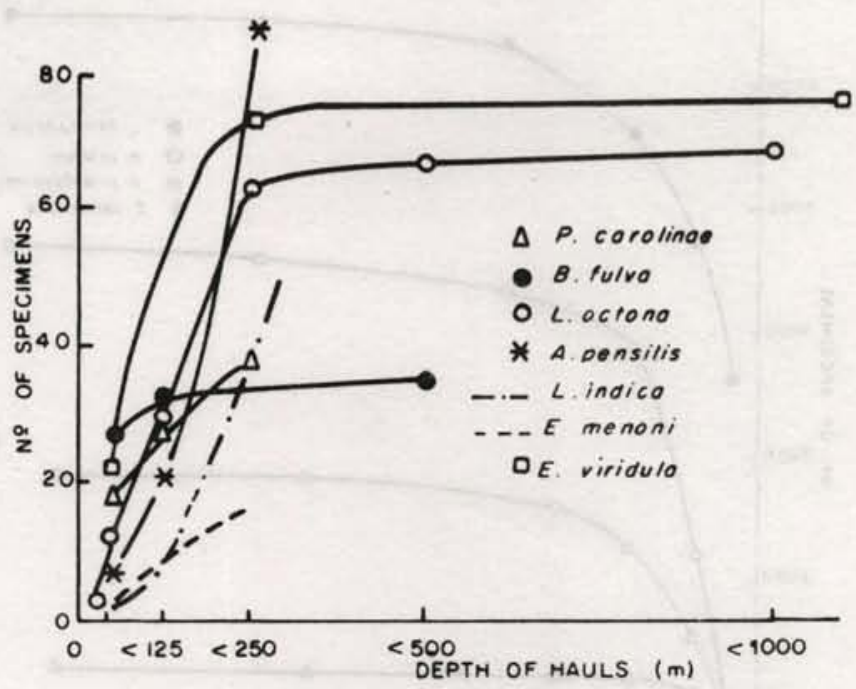

Fig. 11. Cumulative frequency distribution with depth.

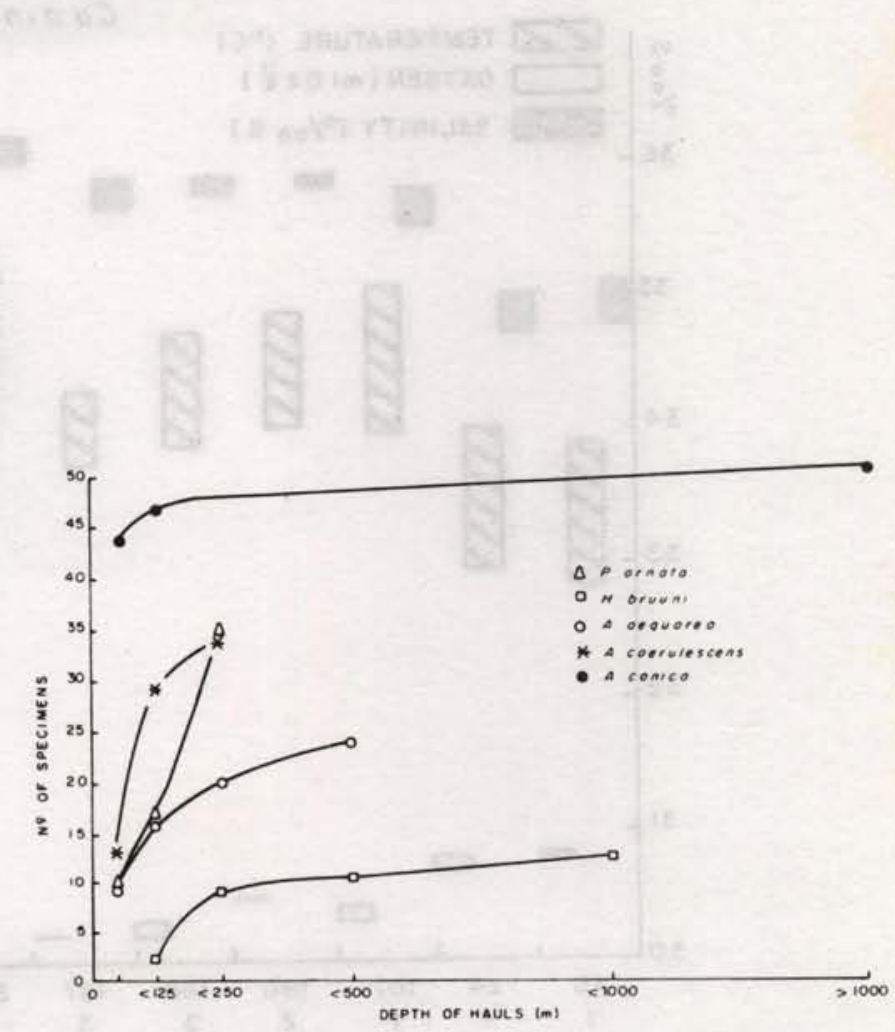

Fig. 13. Cumulative frequency distribution with depth. Halistaura bruuni was never taken in the surface layers. 


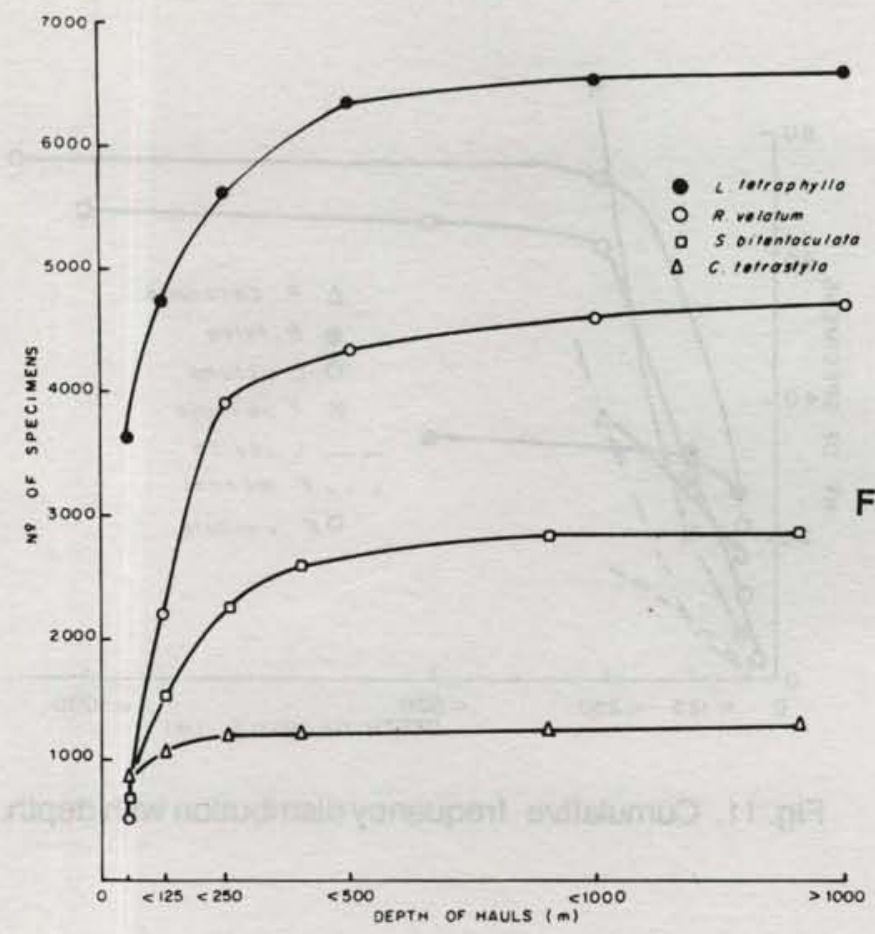

Fig. 14. Cumulative frequency distribution with depth. Cytaeis tetrastyla is a surfacelayer species, while the three others show aggregation at different depths.

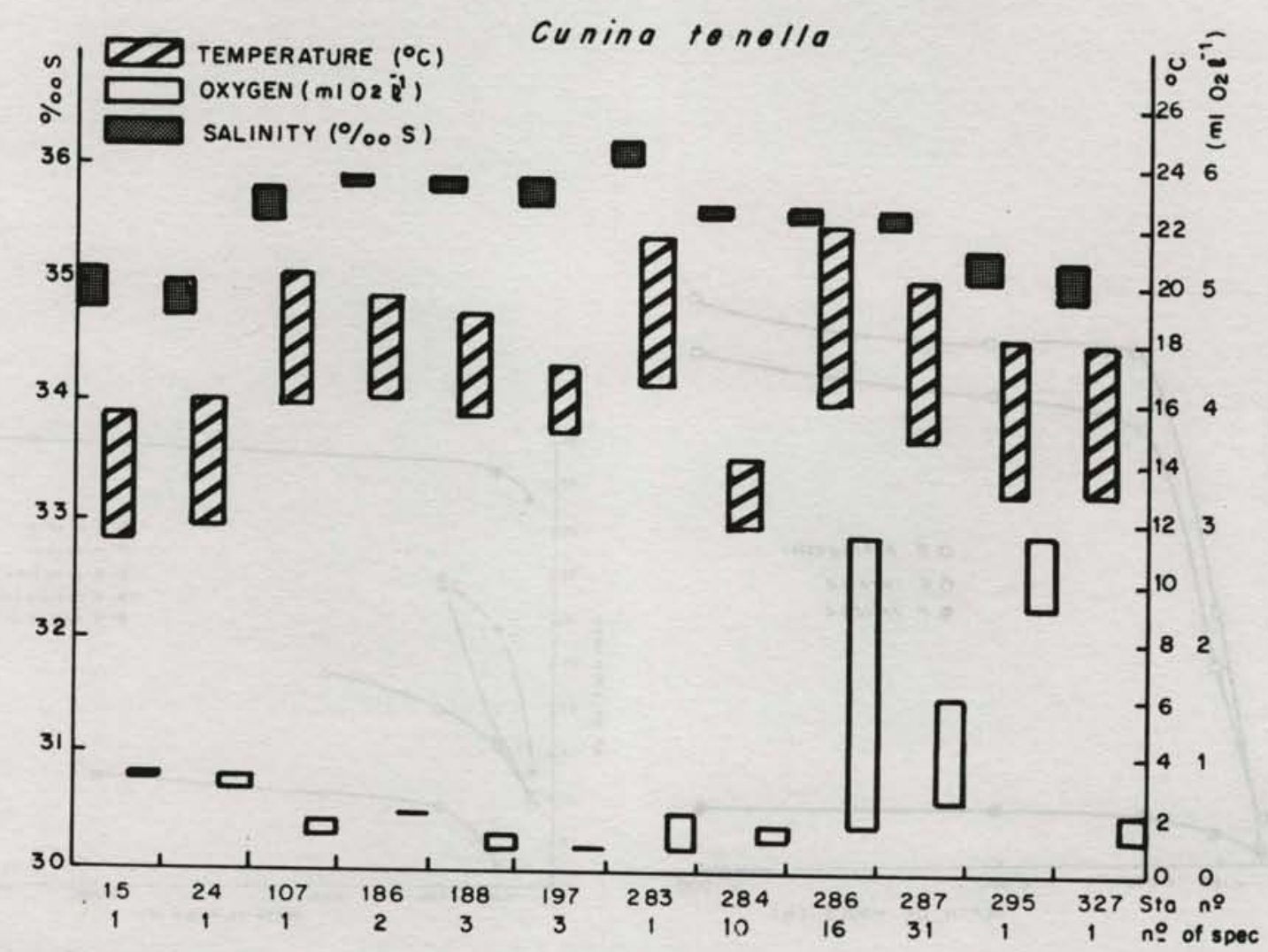

Fig. 15. Selected stations at which Cunina tenella was taken. The figure shows that this is an eurythermal, euryhaline species, widely tolerant of dissolved oxygen content. Figure 12 shows that this species has a boundary layer aggregation. 


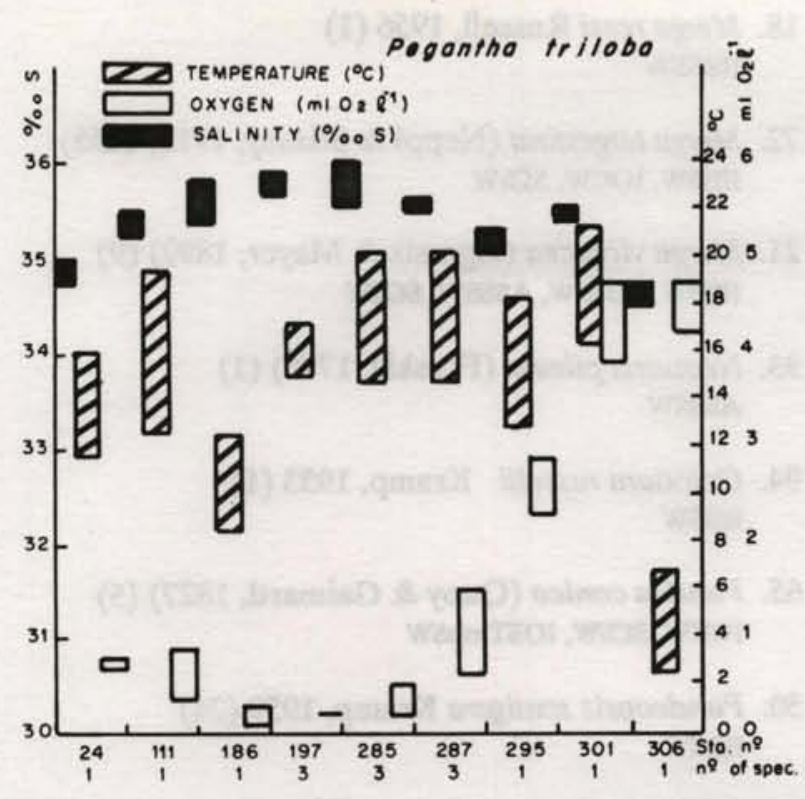

Fig. 16. Selected stations at which Pegantha triloba was found to occur. It shows well marked eurytopic capacity of this species for the three parameters considered, with preference for warm waters; this accounts for its extensive vertical and geographical distribution; see Figure 5. It also shows increased abundance at the boundary layer.

Abbreviations of Water Masses used throughout the text are taken from Gallagher (1966):

ABW - Antarctic Bottom Water

AIW - Antarctic Intermediate Water

ASDW - Arabian Sea Deep Water

ASIW - Arabian Sea Intermediate Water

ASSW - Arabian Sea Surface Water

ASSSW - Arabian Sea SubSurface Water

BBSW - Bay of Bengal Surface Water

BBSSW - Bay of Bengal SubSurface Water

BBDW - Bay of Bengal Deep Water

EIW - Equatorial Intermediate Water

IOCW - Indian Ocean Central Water

IOEW - Indian Ocean Equatorial Water

SCSW - Indian Ocean South Central Surface Water

IOSTempSW - Indian Ocean South Temperate Surface Water

IOSTropSW - Indian Ocean South Tropical Surface Water

NIODW - North Indian Ocean Deep Water

\section{List of species}

Species are listed by family, in taxonomic order, according to Kramp (1961a); numbers before the name are the serial number given in this paper; numbers in brackets indicate number of specimens taken; abbreviations in capitals indicate the water masses through which the net was hauled or those in which the species is known to occur for sure.

\section{ORDER ANTHOMEDUSAE}

Family Tubulariidae

25. Ectopleura sacculifera Kramp, 1957 (5) ASSSW

44. Euphysilla pyramidata Kramp, 1955 (9) BBSSW, ASSW (?), ASSSW, IOCW, IOSTropSW, IOEW (?)

26. Euphysora annulata Kramp, 1928 (6) BBSW

60. Euphysora bigelowi Maas, 1905 (25) BBSW, ASSW (?), ASSSW

1. Euphysora furcata Kramp, 1948 (20) AIW, BBSSW, ASIW, ASSSW, ASDW (?), NIODW (?), ABW (?)

23. Vannuccia forbesi (Mayer, 1894) (7) BBSW, BBSSW, ASSSW, SCSW, IOSTropSW, IOCW (?)

\section{Family Zancleidae}

70. Zanclea costata Gegenbaur, 1856 (8) ASSW, BBSSW, IOEW, IOSTropSW

45. Zanclea dubia Kramp, 1959 (5) BBSW or BBSSW, ASSW or ASSSW, IOSTropSW or IOCW

22. Zanclea orientalis Browne, 1916 (25) BBSW, BBSSW, IOSTropSW, ASSSW, IOCW

61. Zancleopsis tentaculata Kramp, 1928 (5) BBSW, IOCW or IOEW

71. Zancleopsis gotoi (Uchida, 1927) (10) BBSW, BBSSW (?), SCSW

\section{Family Cytaeidae}

62. Cytaeis tetrastyla Eschscholtz, 1829 (1823) ASSW, ASSSW, BBSW, BBSSW, IOEW, IOCW, IOST ropSW, SCSW, ASIW, AIW (?)

Family Clavidae

76. Oceania armata Kölliker, 1853 (4) ASsW

77. Turritopsis nutricula McCrady, 1856 (2) BBSSW, IOCW

Family Hydractiniidae

78. Podocoryne apicata Kramp, 1959 (4) IOCW, ASSSW, ASSW (?) 
79. ? Podocoryne carnea M. Sars, 1846 (1) BBSW, BBSSW (?)

80. ? Podocoryne meteoris Thiel, 1938 (2) ASSW

81. Podocoryne minima (Trinci, 1903) (1) IOSTropsw

\section{Family Bougainvilliidae}

63. Bougainvillia fulva Agassiz \& Mayer, 1899 (36) BBSW, SCSW

82. Bougainvillia maniculata Haeckel, 1879 (1) IOCW

83. Bougainvillia niobe Mayer, 1894 (2) AIW, IOCW, IOSTropsw (?)

64. Bougainvillia platygaster (Haeckel, 1879) (404) BBSw, ASssw, SCSW, IOCW

84. Bougainvillia ramosa (van Beneden, 1844) (17) BBSW

85. Koellikerina constricta (Menon, 1932) (4) BBSW, BBSSW (?)

86. Koellikerina elegans (Mayer, 1900) (1) BBSW

87. Koellikerina fasciculata (Péron \& Lesueur, 1809) (1) ASSW or ASSSW

88. Koellikerina multicirrata (Kramp, 1928) (3) BBSW or BBSSW

27. Koellikerina octonemalis (Maas, 1905) (20) BBSW, BBSSW

\section{Family Pandeidae}

29. Amphinema dinema (Péron \& Lesueur, 1809) (3) BBSW, BBSSW

28. Amphinema nugosum (Mayer, 1900) (25) BBSW, BBSSW

89. ? Cirnhitiara superba (Mayer, 1900) (1) BBSW

90. ? Halitiara formosa Fewkes, 1882 (1) BBSW or BBSSW

91. Leuckartiara gardineri Browne, 1916 (1) BBSW or BBSSW

92. ? Leuckartiara zacae Bigelow, 1940 (2) BBSW or BBSSW, ASSSW

46. Leuckartiara octona (Fleming, 1823) (69) BBSW, BBSSW, ASSW, ASSSW, IOCW or IOEW
18. Merga reesi Russell, 1956 (1) BBSSW

72. Merga tergestina (Neppi \& Stiasny, 1912) (155) BBSW, IOCW, SCSW

21. Merga violacea (Agassiz \& Mayer, 1899) (9) BBSW, BBSSW, ASSSW, SCSW

93. Neoturris pileata (Forskål, 1775) (1) Asssw

94. Octotiara nusselli Kramp, 1953 (1) BBSW

65. Pandea conica (Quoy \& Gaimard, 1827) (5) IOEW, SCSW, IOSTropSW

30. Pandeopsis scutigera Kramp, 1959 (24) BBSW

95. Protiara haeckeli Hargitt, 1902 (1) BBSW

20. Protiara tropica Bigelow, 1912 (14) BBSW, ASSW; ASSSW, SCSW

96. Stomotoca atra L. Agassiz, 1862 (2) BBSW or BBSSW

97. Stomotoca pterophylla Haeckel, 1879 (2) BBSW or BBSSW

\section{Family Calycopsidae}

98. Calycopsis papillata Bigelow, 1918 (1) ASsW or ASSSW

99. Calycopsis simulans (Bigelow, 1909) (1) IOEW or IOCW

73. Heterotiara anonyma Maas, 1905 (7) ASSW, BBSW (?), BBSSW

47. Heterotiara minor Vanhöffen, 1911 (27) ASSW or ASSSW, BBSW or BBSSW, IOEW or IOCW

100. Sibogita geometrica Maas, 1905 (2) IOCW, AIW (?)

\section{ORDER LEPTOMEDUSAE}

Family Laodiceidae

66. Laodicea fijiana Agassiz \& Mayer, 1899 (96) IOEW, BBSW or BBSSW, ASSW or ASSSW

31. Laodicea indica Browne, 1905 (51) BBSW

101. Melicertissa mayeri Kramp, 1959 (1) ASSW or ASSSW 
102. Melicertissa orientalis Kramp, 1961 (2) BBSW

103. Ptychogena hyperborea Kramp, 1942 (1) IOCW or EIW

104. Staurodiscus tetrastaurus Haeckel, 1879 (2) BBSW, SCSW

105. Toxorchis polynema Kramp, 1959 (3) BBSW or BBSSW

106. Taxorchis thalassinus (Péron \& Lesueur, 1809) (2) BBSW

107. Toxorchis sp. (2) BBSW, BBSSW

\section{Family Mitrocomidae}

32. Halistaura bnuuni Navas, 1969 (13) BBSW, BBSSW

\section{Family Campanulariidae}

108. Obelia spp. (17) BBSW, BBSSW, ASSW, ASSSW

74. Phialidium hemisphaericum (L.) (18) BBSW, BBSSW, IOEW or IOCW

109. Phialidium mccradyi (Brooks, 1888) (1) BBSW or BBSSW

110. Phialidium simplex Browne, 1902 (1) BBSW

\section{Family Lovenellidae}

111. Cirrholovenia tetranema Kramp, 1959 (2) BBSW

112. Eucheilota duodecimalis A. Agassiz, 1862 (1) BBSW or BBSSW

67. Eucheilota menoni Kramp, 1959 (16)

BBSW or BBSSW, ASSW or ASSSW, SCSW, IOSTropSW (?)

113. Eucheilota tropica Kramp, 1959 (3) BBSW

114. Lovenella assimilis (Browne, 1905) (1) BBSW

33. Lovenella cirrata (Haeckel, 1879) (5) BBSW

\section{Family Phialellidae}

115. Phialella falklandica Browne, 1902 (1) IOEW or IOCW
116. Phialella quadrata (Forbes, 1848) (1) BBSW

Family Phialuciidae

117. Octophialucium bigelowi Kramp, 1955 (1) BBSW

34. Octophialucium indicum Kramp, 1958 (69) BBSW

118. Octophialucium medium Kramp, 1955 (2) BBSW, ASsSW

35. Phialucium carolinae (Mayer, 1900) (38) BBSW or BBSSW

119. Phialucium condensum Kramp, 1953 (1) BBSW

36. Phialucium multitentaculatum Menon, 1932 (9) BBSW

\section{Family Eirenidae}

120. Eirene brevigona Kramp, 1959 (2) ASSW or ASSSW

37. Eirene elliceana (Agassiz \& Mayer, 1902) (5) BBSW, BBSSW

38. Eirene hexanemalis (Goette, 1886) (12) BBSW, BBSSW

68. Eirene viridula (Péron \& Lesueur, 1809) (76) BBSW, ASSW or ASSSW, IOSTempSW, SCSW

121. Helgicirrha malayensis (Stiasny, 1928) (2) BBSW or BBSSW

122. Helgicirna medusifera (Bigelow, 1909) (2) BBSW or BBSSW

\section{Family Eutimidae}

123. Eutima curva Browne, 1905 (1) ASSW or ASSSW

124. Eutima gentiana (Haeckel, 1879) (9) IOSTropsw

125. Eutima mira McCrady, 1857 (5) IOEW, IOSTropSW

126. Eutima orientalis (Browne, 1905) (2) BBSW, BBSSW (?)

Family Aequoreidae

69. Aequorea aequorea (Forskål, 1775) (24) BBSW, IOEW or IOCW, ASSW 
39. Aequorea coenulescens (Brandt, 1838) (34) BBSW

75. Aequorea conica Browne, 1905 (50)

BBSW, IOSTempSW, AIW (?)

127. Aequorea globosa Eschscholtz, 1829 (2) BBSW, BBSSW (?)

48. Aequorea macrodactyla Brandt, 1835 (13) BBSW or BBSSW, ASSSW, IOCW, IOSTropSW, SCSW or AIW

128. Aequorea parva Browne, 1905 (2) IOSTempSW or AIW

19. Aequorea pensilis (Eschscholtz, 1829) (87) BBSW or BBSSW, IOCW, ASSW or ASSSW

\section{ORDER LIMNOMEDUSAE}

\section{Family Olindiadidae}

40. Olindias singularis Browne, 1905 (7) BBSW

\section{Family Proboscidactylidae}

49. Proboscidactyla ornata (McCrady, 1857) (35) BBSW or BBSSW, IOSTropSW, ASSW or ASSSW, IOEW or IOCW, SCSW

\section{ORDER TRACHYMEDUSAE}

\section{Family Geryonidae}

50. Geryonia proboscidalis (Forskål, 1775) (13) IOCW, IOSTropSW, BBSW or BBSSW, ASSW or ASSSW

41. Liniope tetraphylla (Chamisso \& Eysenhardt, 1821) (7217)

\section{Family Halicreatidae}

2. Botrynema brucei Browne, 1908 (37) AIW or ASSSW, BBSSW

3. Halicreas minimum Fewkes, 1882 (191) IOCW, AIW, ASIW, ASSSW, IOSTropSW

4. Haliscera racovitzae (Maas, 1906) (2) BBSSW

5. Halitrephes maasi Bigelow, 1909 (22) IOCW, BBSSW, AIW
Family Rhopalonematidae

6. Aglantha elata (Haeckel, 1879) (5) AIW, IOCW

42. Aglaura hemistoma (Péron \& Lesueur, 1809) (13047)

51. Amphogona apicata (Kramp, 1957) (181) IOCW, ASSSW, BBSSW

129. Amphogona apsteini Vanhöffen, 1902 (1) ASSW

7. Colobonema sericeum (Vanhöffen, 1902) (638) IOCW, BBSSW, ASSSW

8. Crossota alba Bigelow, 1913 (3) AIW, IOCW, BBSSW

9. Crossota brunnea Vanhöffen, 1902 (45) AIW, IOCW, NIODW

10. Pantachogon haeckeli Maas, 1893 (230) ASSW, ASSSW, ASIW, EIW, IOCW, AIW, NIODW

130. Pantachogon scotti Browne, 1910 (2) ASSW, ASSSW, ASIW

52. Persa incolorata McCrady, 1857 (119) BBSW, BBSSW, ASSSW, IOCW, AIW

53. Rhopalonema velatum Gegenbaur, 1856 (5301) BBSW, BBSSW, ASSW, ASSSW, IOCW, IOSTropsW, SCSW, AIW

54. Sminthea eurygaster Gegenbaur, 1856 (143) IOCW, BBSW, BBSSW, ASSSW, EIW, SCSW, IOSTropSW

17. Tetrorchis erythrogaster Bigelow, 1909 (8) ASSSW

\section{ORDER NARCOMEDUSAE}

Family Aeginidae

11. Aegina citrea Eschscholtz, 1829 (42) BBSSW, IOCW, ASIW, SCSW, EIW, AIW, IOSTropSW

12. Aeginura grimaldii Maas, 1904 (46) BBSSW, AIW, IOCW, ASIW, EIW

55. Solmundella bitentaculata (Quoy \& Gaimard, 1833) (3113) ASSW, ASSSW, BBSW, BBSSW, IOEW, IOCW, IOSTropSW

\section{Family Solmariidae}

15. Pegantha clara R. P. Bigelow, 1909 (21) ASSW, ASSSW, BBSW, SCSW 
24. Pegantha laevis H. B. Bigelow, 1909 (28) BBSW, IOEW, SCSW

16. Pegantha martagon Haeckel, 1879 (932) ASSW, ASSSW, BBSW, IOCW, IOEW

56. Pegantha triloba Haeckel, 1879 (57) ASSW, ASSSW, BBSW, BBSSW, IOEW, IOSTropSW, AIW

131. Solmaris rhodoloma (Brandt, 1838) (1) BBSW or BBSSW

\section{Family Cuninidae}

13. Cunina duplicata Maas, 1893 (5) ASSSW, BBDW, AIW

57. Cunina frugifera Kramp, 1948 (60) BBSW, BBSSW, ASSW, ASSSW, IOSTropSW, IOCW

58. Cunina octonaria McCrady, 1857 (496) BBSW, ASSW, ASSSW, IOEW, IOCW, IOSTropSW, SCSW, EIW

59. Cunina peregrina Bigelow, 1909 (132) BBSW, BBSSW, ASSW, ASSSW, SCSW, IOSTropSW, IOCW

43. Cunina tenella (Bigelow, 1909) (427) ASSW, ASSSW, BBSW, BBSSW, IOEW, SCSW, IOSTropSW

14. Solmissus marshalli Agassiz \& Mayer, 1902 (40) BBSW, BBSSW, ASIW, SCSW, ASSW, ASSSW, IOCW, AIW, IOSTropSW

\section{Ecological distribution of selected species}

Tables 1 and 2 summarize background information on the water masses of the Indian Ocean and give the ecological valence of each species that could be established with certainty. Wherever there was insufficient information or impossibility of establishing with any degree of accuracy the limits of ecological tolerance, the wider limits were entered in the tables and discussion of the species.

\section{Antarctic and Sub-Antarctic cold and deep water species}

The structure and dynamics of the Antarctic Ocean influences the structure and dynamics of oceanic water masses of the three major oceans, the Atlantic, Pacific and Indian Oceans. While the first two extend from the Arctic to the Antarctic, the Indian Ocean is bound at latitudes of roughly $20^{\circ} \mathrm{N}$ by the Asian landmass, consequently the circulation pattern of the Indian Ocean water masses differs from that of the Atlantic and Pacific Oceans. The influence of the Antarctic Ocean where cold to very cold, oxygen rich and low salinity waters are formed, sink and spread to lower latitudes, however it follows the same general pattern in the three major oceans. For this reason, we begin our discussion with the cold-living species of Antarctic, sub-Antarctic and deep waters of the Indian Ocean and proceed to those waters that derive from them.

Except for Euphysora furcata all the following species are holoplanktonic. The hydroids of the many species of the family Tubulariidae to which Euphysora belongs are known to be long lived and inhabit great depths.

1. Euphysora furcata Kramp, 1948, Figs 2, 3. Twenty specimens, deep hauls, stratified samples; a deep cold water species. Repeatedly taken in AIW that is formed by sinking at the Antarctic Convergence and flows north. From this water mass it spreads into BBSSW, ASIW and ASSSW. It is not sure whether it can live also in deeper layers such as ASDW, NIODW and ABW. When found near to or at the surface, it is a sure sign of upwelled waters. Its optima are around $34.8 \%$ o salinity, $5-9^{\circ} \mathrm{C}$ temperature and $3 \mathrm{ml} / \mathrm{l}$ dissolved oxygen. Its limits of tolerance are 34.7 to $35.3 \%$ salinity; $4^{\circ} \mathrm{C}$ or lower to $12^{\circ} \mathrm{C}$ temperature or perhaps higher; 1.8 or lower to $4.2 \mathrm{ml} / \mathrm{l}$ dissolved oxygen content. It therefore appears to be stenohaline, relatively eurythermal and tolerant of low oxygen content. One single specimen was taken in surface waters in $36.0 \%$ salinity, $24.9^{\circ} \mathrm{C}$ temperature and $4.6 \mathrm{ml} / 1$ dissolved oxygen content; this was in upwelled waters at the mouth of the Gulf of Aden and the specimen was dead when taken, probably due to mixing with high salinity and high temperature waters.

It is widely distributed, mainly in upwelling areas (Kramp, 1955, 1957, 1959a, on the west coast of Africa), and Navas-Pereira (in press) found it in sub-Antarctic waters.

2. Botrynema brucei Browne, 1908 , Figs 4,5 . Thirty seven specimens, an Antarctic species. Spreads into the Indian Ocean through AIW. It was taken in AIW or at the boundary with water masses above the AIW or at lower levels, between ASSSW and BBSSW and surface waters. The salinity range was 34.4 to $35.6 \%$; the temperature range was from $5.8^{\circ} \mathrm{C}$ (or lower) to $16^{\circ} \mathrm{C}$; oxygen content not lower than $2.8 \mathrm{ml} / \mathrm{\text { }}$. A single specimen taken in the Bay of Bengal, in BBSSW was probably dead when taken, oxygen content was about $1 \mathrm{ml} / \mathrm{l}$. Seventy percent of the specimens come from $40^{\circ} \mathrm{S}$ lat. in the area of the sub-tropical convergence, they were taken in two hauls, one from $2750-275 \mathrm{~m}$ depth and the other from $885-0 \mathrm{~m}$.

Earlier records are from deep waters of the Pacific, Indian and Atlantic Oceans (Kramp, 1959a, 1968) and from the Antarctic (Navas-Pereira, in press).

3. Halicreas minimum Fewkes, 1882, Fig. 6. Antarctic species; 191 specimens; sinks at the subtropical convergence and probably also at the sub-Antarctic convergence; spreads as far as $07^{\circ} 27^{\prime} \mathrm{N}$ in the Bay of Bengal (one specimen) and $07^{\circ} 55^{\circ} \mathrm{N}$ in the Arabian Sea (two specimens); 19 specimens were taken between $7^{\circ} \mathrm{N}$ and the Equator in ASIW and ASSSW. The pattern is similar to that of other Antarctic species that sink at the convergence and rise at the Equator and in the northern hemisphere as waters of Antarctic origin mix and rise to shallower depths as they loose their identity. Increase of temperature, lowering or increase of salinity and decrease of dissolved oxygen content are the limiting factors in the distribution of this species that is clearly associated with low temperatures of Antarctic or deep waters. The limits within which it was taken were: 34.6 to $35.5 \%$ salinity; $5^{\circ} \mathrm{C}$ (probably tolerates down to $2.8^{\circ} \mathrm{C}$ ) to $13.4^{\circ} \mathrm{C}$ temperature. 
Table 1. Water masses of the Indian Ocean

a. Bay of Bengat

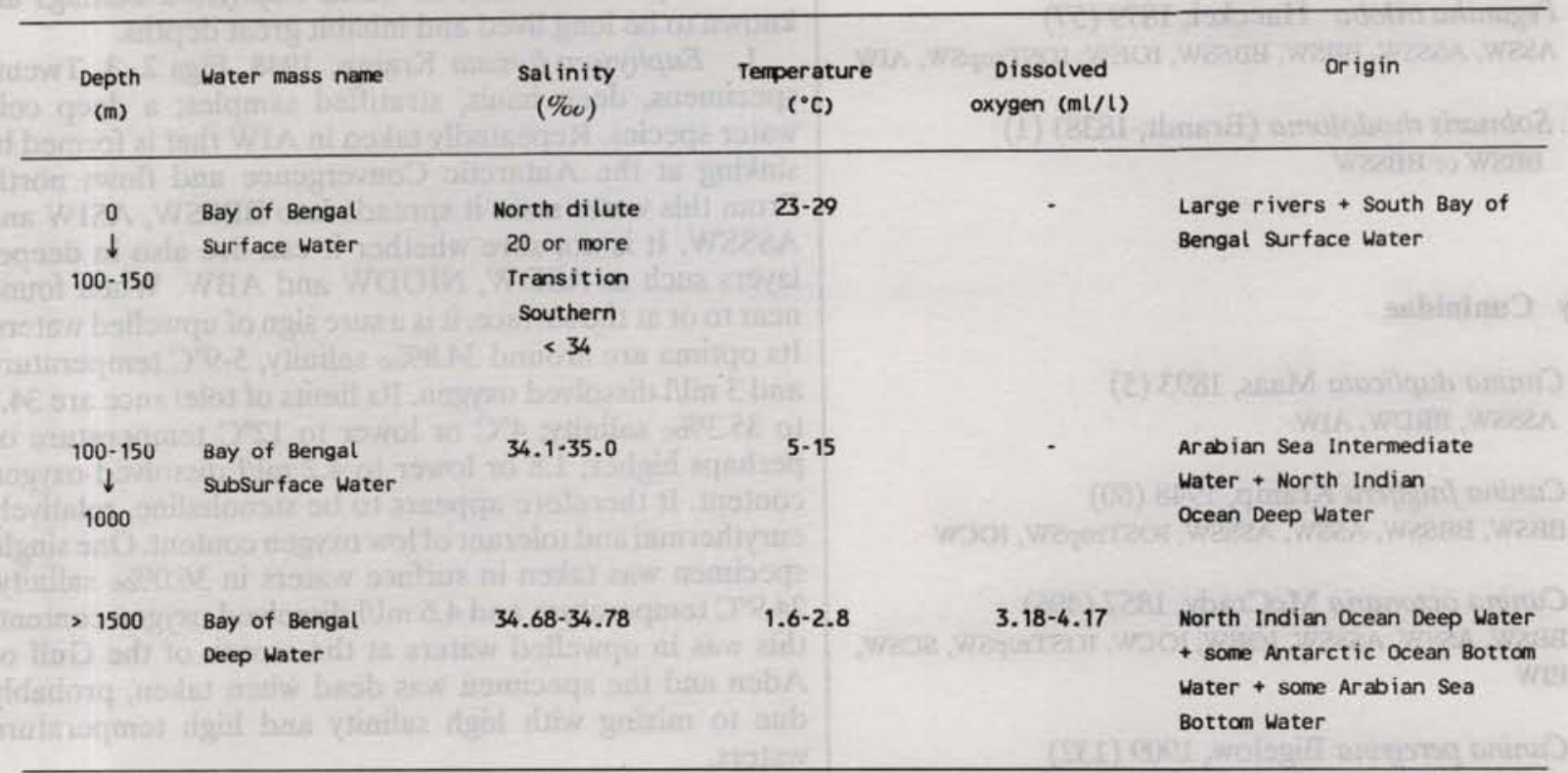

b. Central and Southern Indian Ocean

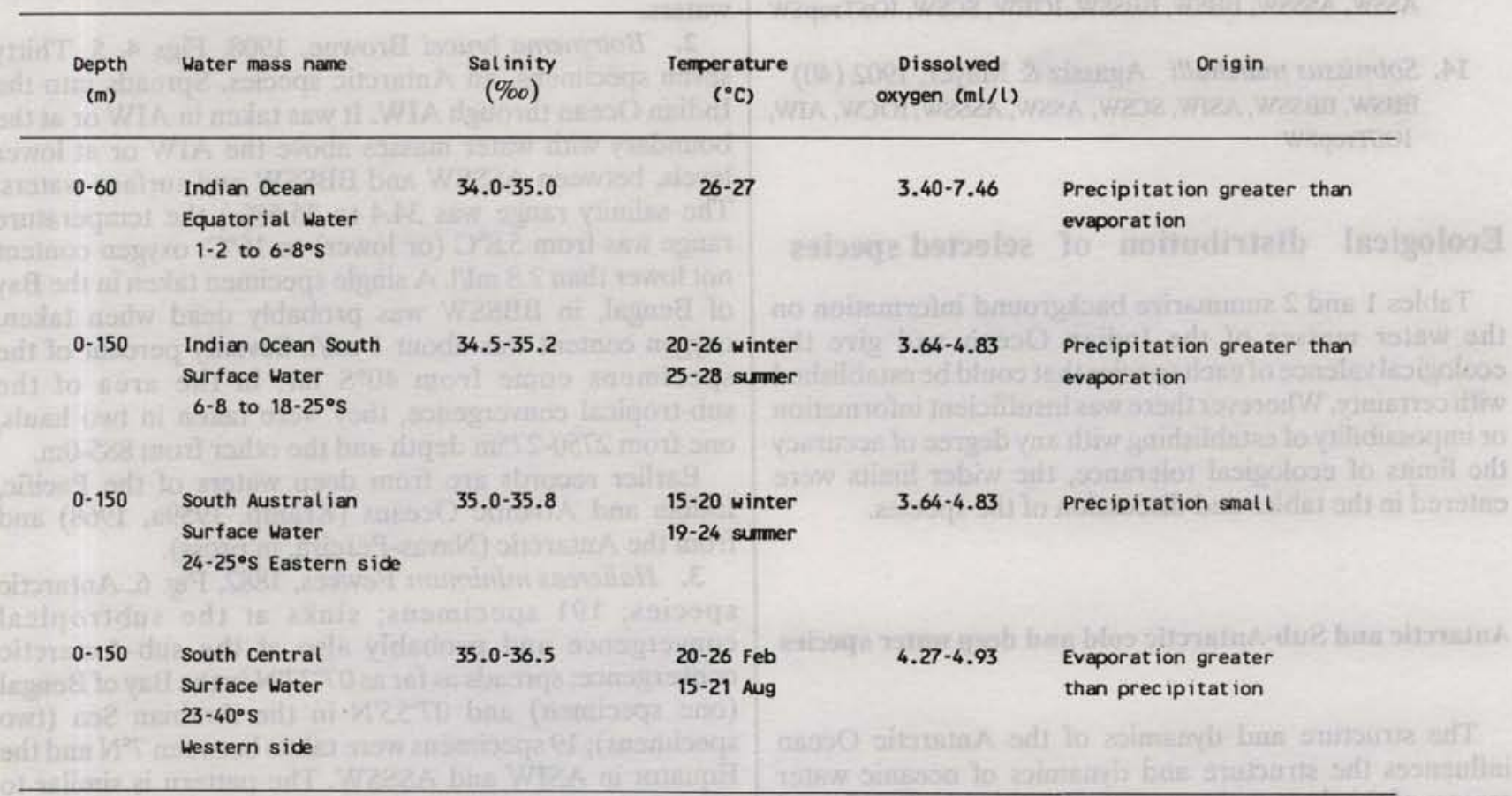


Table 1. (Cont.)

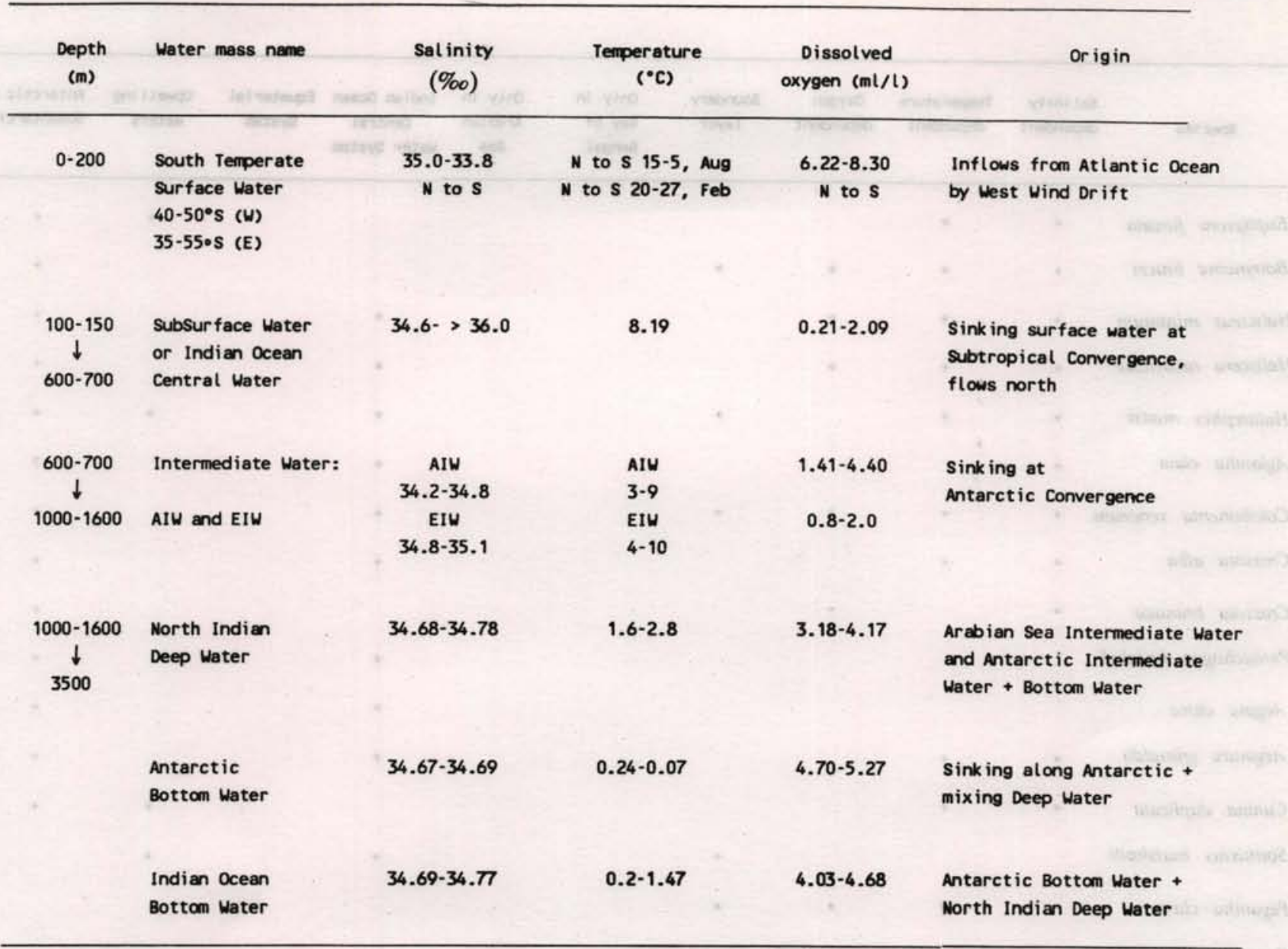

c. Arabian Sea

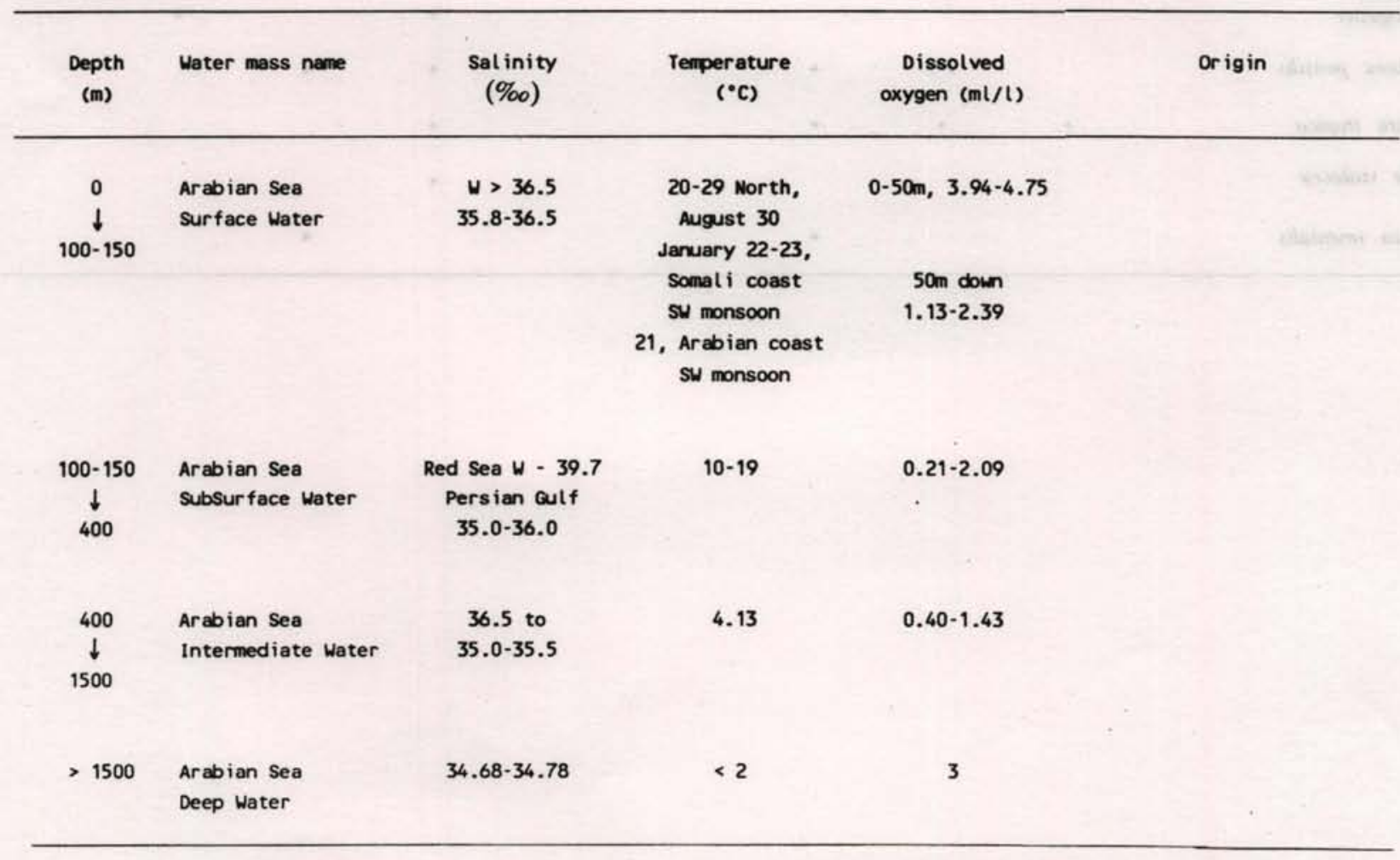


Table 2. Ecological distribution of the hydromedusae taken during the IIOE

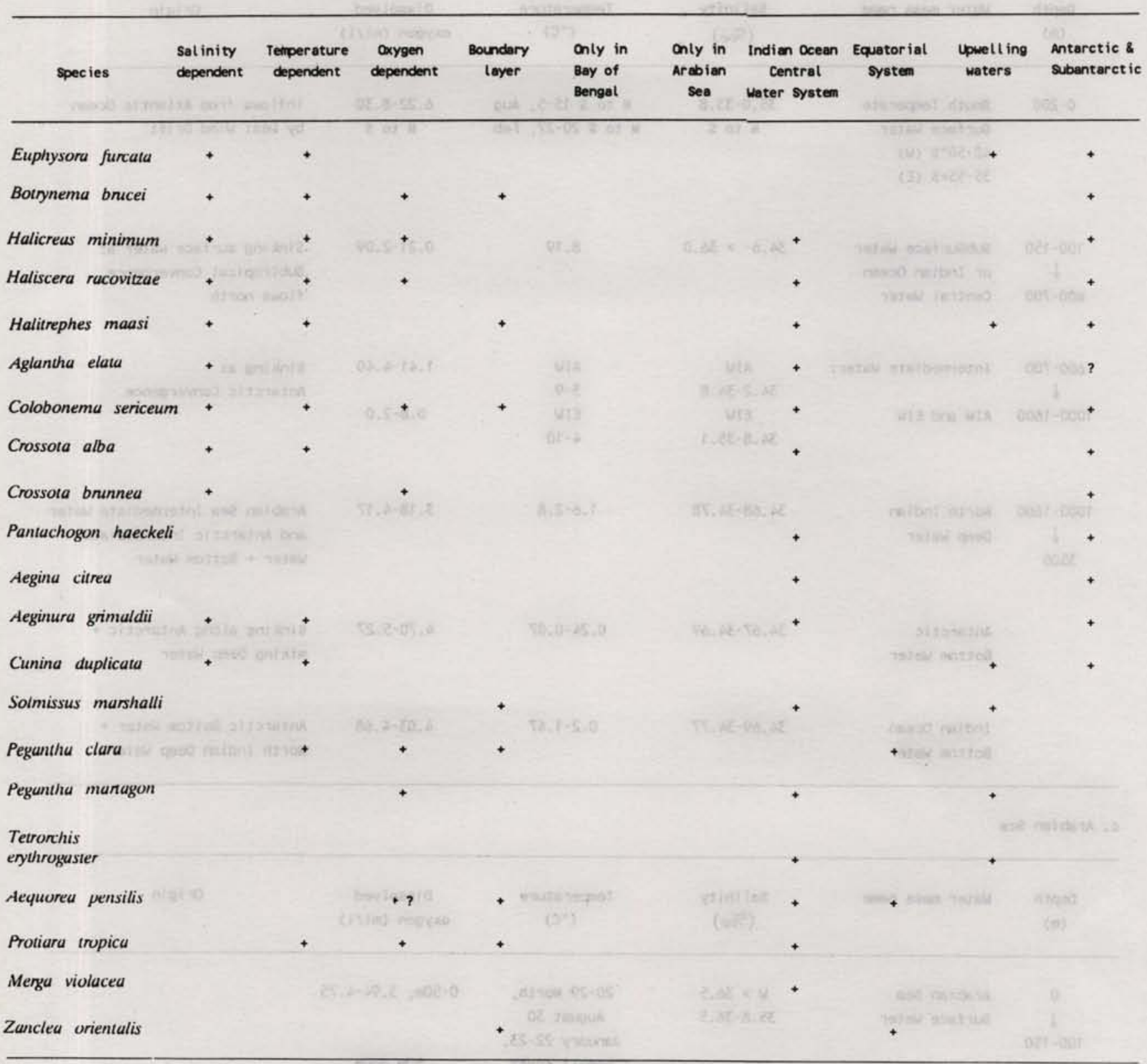


Table 2. (Cont.)

\begin{tabular}{|c|c|c|c|c|c|c|c|c|c|c|}
\hline Species & $\begin{array}{l}\text { Sal inity } \\
\text { dependent }\end{array}$ & $\begin{array}{l}\text { Temperature } \\
\text { dependent }\end{array}$ & $\begin{array}{l}\text { axygen } \\
\text { dependent }\end{array}$ & $\begin{array}{c}\text { Boundary } \\
\text { layer }\end{array}$ & $\begin{array}{l}\text { only in } \\
\text { Bay of } \\
\text { Bengal }\end{array}$ & $\begin{array}{l}\text { only in } \\
\text { Arabian } \\
\text { Sea }\end{array}$ & $\begin{array}{l}\text { Indian Ocean } \\
\text { Central } \\
\text { Water system }\end{array}$ & $\begin{array}{l}\text { Equatorial } \\
\text { System }\end{array}$ & $\begin{array}{l}\text { Upwell ing } \\
\text { waters }\end{array}$ & $\begin{array}{l}\text { Antarctic \& } \\
\text { Subantarctic }\end{array}$ \\
\hline $\begin{array}{l}\text { Zancleopsis } \\
\text { tentaculata }\end{array}$ & + & + & & + & nat & & & + & & \\
\hline Cyraeis tetrastyla & widely & $\begin{array}{c}\text { distr ibuted, } \\
+\end{array}$ & tropical, & subtropical, & temperate, & surface & $=$ & + & & \\
\hline Bougainvillia fulva & & + & + & & & & $=$ & + & & \\
\hline $\begin{array}{l}\text { Bougainvillia } \\
\text { platygaster }\end{array}$ & widely & distributed, & tropical, & subtropical, & surface & & & 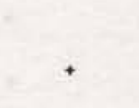 & & \\
\hline Pundeu conica & & & + & & & & & + & & \\
\hline Luodicea fijiana & + & + & + & + & & & & + & & \\
\hline Eucheilota menoni & & + & + & + & x & & & + & & \\
\hline Eirene viridula & & & + & + & $\bar{x}$ & & & 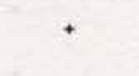 & & \\
\hline Aequorea aequorea & + & + & + & & & & & 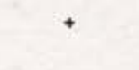 & & \\
\hline Zanclea costata & + & + & + & + & te & & & & 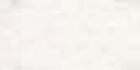 & \\
\hline Zuncleopsis gotoi & + & + & + & & $t$ & & & & & \\
\hline Merga tergestina & + & + & + & & & & & & & \\
\hline Heterotiara anonyma & + & & & + & & & & & & \\
\hline $\begin{array}{l}\text { Phialidium } \\
\text { hemisphaericum }\end{array}$ & + & + & + & & & & & & & \\
\hline Aequorea conica & + & & + & & & & & & . & \\
\hline
\end{tabular}


Table 2. (Cont.)

\begin{tabular}{|c|c|c|c|c|c|c|c|c|c|c|}
\hline species & $\begin{array}{l}\text { Sal inity } \\
\text { dependent }\end{array}$ & $\begin{array}{l}\text { Temperature } \\
\text { dependent }\end{array}$ & $\begin{array}{l}\text { axygen } \\
\text { dependent }\end{array}$ & $\begin{array}{c}\text { Boundary } \\
\text { layer }\end{array}$ & $\begin{array}{l}\text { Only in } \\
\text { Bay of } \\
\text { Bengal }\end{array}$ & $\begin{array}{c}\text { Only in } \\
\text { Arabian } \\
\text { Sea }\end{array}$ & $\begin{array}{l}\text { Indian Ocean } \\
\text { Central } \\
\text { Water System }\end{array}$ & $\begin{array}{l}\text { Equatorial } \\
\text { System }\end{array}$ & $\begin{array}{l}\text { Upwell ing } \\
\text { waters }\end{array}$ & $\begin{array}{l}\text { Antarctic \& } \\
\text { Subantarct ic }\end{array}$ \\
\hline
\end{tabular}

Vannuccia forbesi

high food

content

$+$

Pegantha laevis

Ectopleura

sacculifera

Euphysora annulata

Koellikerina

octonemalis

Amphinema nugosum

Pandeopsis scutigera

Laodicea indica

Halistaura brumi

Lovenella cirrata

Octophialucium indicum

Phialucium carolinae

Phialucium

multitentaculatum

Eirene elliceana

Eirene hexanemalis

Aequorea

coerulescens

Olindias singularis

Liriope tetraphylla

widely distributed 
Table 2. (Cont.)

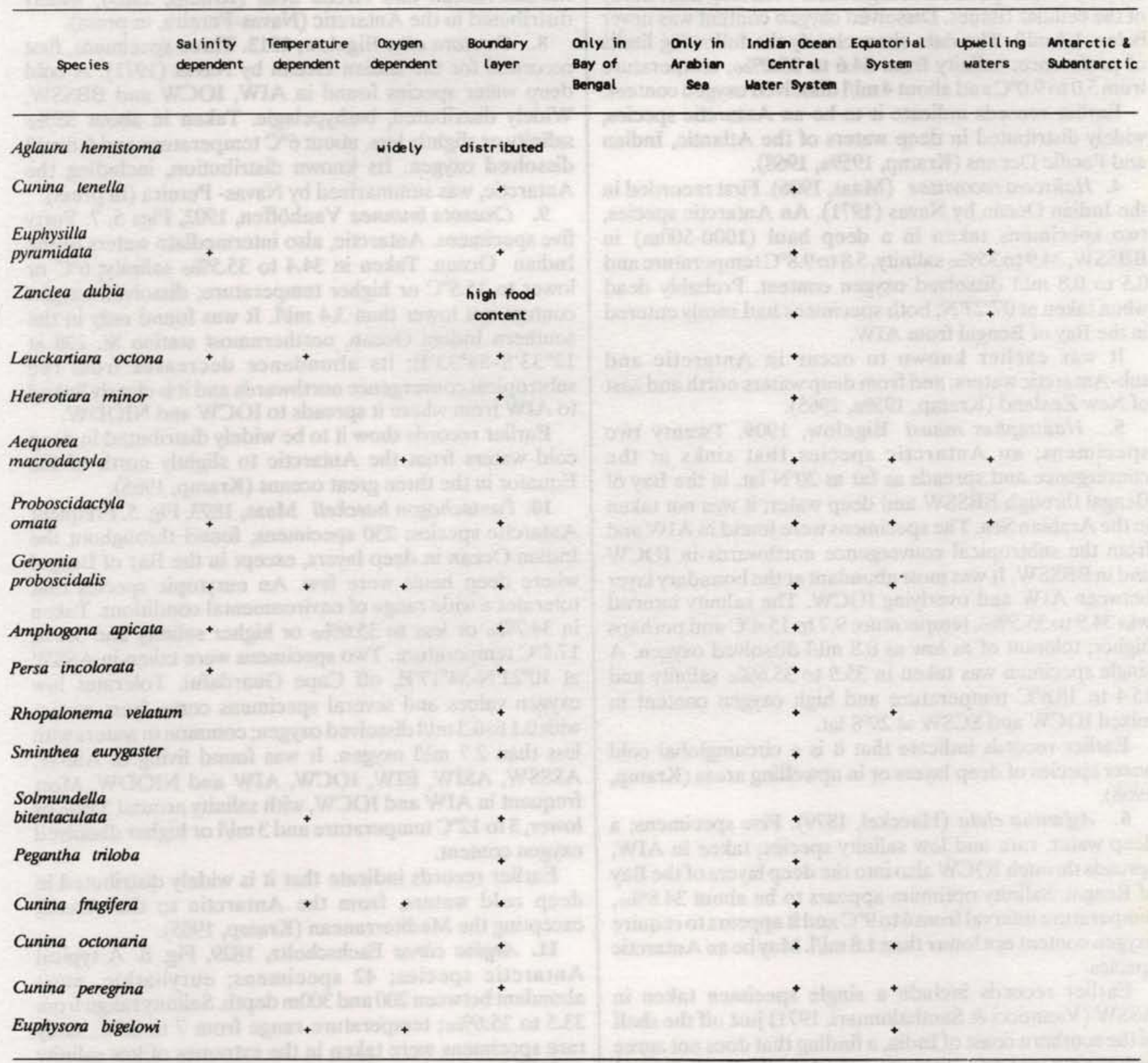


Two specimens were taken in higher temperature, one in IOCW at $29^{\circ} 22^{\prime} \mathrm{S}$ with $18.4^{\circ} \mathrm{C}$ and one in IOSTropSW at up to $23^{\circ} \mathrm{C}$. These specimens were probably already dead when they were taken since only the mesogloea was left; the jelly of this species is recognizable even long after decay of the cellular tissues. Dissolved oxygen content was never below $1.4 \mathrm{ml} / 1$. The data show clearly the following limits of preference: salinity from 34.6 to $35.0 \%$, temperature from 5.0 to $9.0^{\circ} \mathrm{C}$ and about $4 \mathrm{ml} / 1$ dissolved oxygen content.

Earlier records indicate it to be an Antarctic species, widely distributed in deep waters of the Atlantic, Indian and Pacific Oceans (Kramp, 1959a, 1968).

4. Haliscera racovitzae (Maas, 1906). First recorded in the Indian Ocean by Navas (1971). An Antarctic species, two specimens taken in a deep haul $(1000-500 \mathrm{~m})$ in BBSSW, 34.9 to $35 \%$ salinity, 5.8 to $9.8^{\circ} \mathrm{C}$ temperature and 0.5 to $0.8 \mathrm{ml} / 1$ dissolved oxygen content. Probably dead when taken at $07^{\circ} 27 \mathrm{~N}$; both specimens had surely entered in the Bay of Bengal from AIW.

It was earlier known to occur in Antarctic and sub-Antarctic waters, and from deep waters north and east of New Zealand (Kramp, 1959a, 1965).

5. Halitrephes maasi Bigelow, 1909. Twenty two specimens; an Antarctic species that sinks at the convergence and spreads as far as $20^{\circ} \mathrm{N}$ lat. in the Bay of Bengal through BBSSW and deep water; it was not taken in the Arabian Sea. The specimens were found in AIW and from the subtropical convergence northwards in IOCW and in BBSSW. It was most abundant at the boundary layer between AIW and overlying IOCW. The salinity interval was 34.9 to $35.5 \%$, temperature 9.7 to $15.4^{\circ} \mathrm{C}$ and perhaps higher; tolerant of as low as $0.8 \mathrm{ml} / 1$ dissolved oxygen. A single specimen was taken in 35.5 to $35.6 \%$ salinity and 15.4 to $18.8^{\circ} \mathrm{C}$ temperature and high oxygen content in mixed IOCW and SCSW at $29^{\circ}$ S lat.

Earlier records indicate that it is a circumglobal cold water species of deep layers or in upwelling areas (Kramp, 1968).

6. Aglantha elata (Haeckel, 1879). Five specimens; a deep water, rare and low salinity species; taken in AIW, spreads through IOCW also into the deep layers of the Bay of Bengal. Salinity optimum appears to be about $34.8 \%$, temperature interval from 6 to $9^{\circ} \mathrm{C}$ and it appears to require oxygen content not lower than $1.8 \mathrm{ml} /$. May be an Antarctic species.

Earlier records include a single specimen taken in ASSW (Vannucci \& Santhakumari, 1971) just off the shelf of the southern coast of India, a finding that does not agree with the present ones since it comes from high salinity and high temperature waters. Kramp (1959a) mentions that it is found in upwelling areas, but none of our specimens come from such waters.

7. Colobonema sericeum Vanhöffen, 1902, Fig. 6. An Antarctic species, abundantly represented throughout the Indian Ocean; 638 specimens taken. Most abundant in IOCW where the greatest densities are found; it aggregates at the upper boundaries of the IOCW; a boundary layer species, not taken in surface waters. Found also in BBSSW and other boundary areas. Salinity interval from 34.7 to $35.7 \%$; temperature from 6 to $18^{\circ} \mathrm{C}$ and perhaps lower; oxygen content not lower than $2 \mathrm{ml} / 1$. Preference for temperatures from 9 to $12^{\circ} \mathrm{C}$ and high oxygen content. Density of specimens decreases sharply from south northwards; limiting factors are high temperature, higher salinity and lower oxygen content.

Earlier records show it to be a widely distributed bathypelagic species, circumglobal except for the Mediterranean and Arctic Seas (Kramp, 1965); widely distributed in the Antarctic (Navas-Pereira, in press).

8. Crossota alba Bigelow, 1913. Three specimens, first recorded for the Indian Ocean by Navas (1971). A cold deep water species found in AIW, IOCW and BBSSW. Widely distributed, bathypelagic. Taken in about $35 \%$ salinity or slightly less, about $6^{\circ} \mathrm{C}$ temperature and $0.8 \mathrm{ml} / 1$ dissolved oxygen. Its known distribution, including the Antarctic, was summarized by Navas- Pereira (in press).

9. Crossota brunnea Vanhöffen, 1902, Figs 5, 7. Forty five specimens. Antarctic, also intermediate waters of the Indian Ocean. Taken in 34.4 to $35.5 \%$ salinity; $6^{\circ} \mathrm{C}$ or lower to $15.5^{\circ} \mathrm{C}$ or higher temperature; dissolved oxygen content not lower than $3.4 \mathrm{ml} / \mathrm{l}$. It was found only in the southern Indian Ocean, northernmost station St. 298 at $12^{\circ} 33^{\prime} \mathrm{S}-54^{\circ} 33^{\prime} \mathrm{E}$; its abundance decreases from the subtropical convergence northwards and it is clearly linked to AIW from where it spreads to IOCW and NIODW.

Earlier records show it to be widely distributed in deep cold waters from the Antarctic to slightly north of the Equator in the three great oceans (Kramp, 1965).

10. Pantachogon haeckeli Maas, 1893, Fig. 5. Frequent Antarctic species; 230 specimens, found throughout the Indian Ocean in deep layers, except in the Bay of Bengal where deep hauls were few. An eurytopic species that tolerates a wide range of environmental conditions. Taken in $34.7 \%$ or less to $35.6 \%$ or higher salinity and 3.4 to $17.1^{\circ} \mathrm{C}$ temperature. Two specimens were taken in ASSW at $10^{\circ} 21^{\prime} \mathrm{N}-54^{\circ} 1 \mathrm{TE}$, off Cape Guardafui. Tolerates low oxygen values and several specimens come from waters with 0.1 to $0.3 \mathrm{ml} / 1$ dissolved oxygen; common in waters with less than $2.7 \mathrm{ml} / 1$ oxygen. It was found living in ASSW, ASSSW, ASIW, EIW, IOCW, AIW and NIODW. Most frequent in AIW and IOCW, with salinity around $35 \%$ or lower, 3 to $12^{\circ} \mathrm{C}$ temperature and $3 \mathrm{ml} / 1$ or higher dissolved oxygen content.

Earlier records indicate that it is widely distributed in deep cold waters, from the Antarctic to the Arctic, excepting the Mediterranean (Kramp, 1965).

11. Aegina citrea Eschscholtz, 1829, Fig. 8. A typical Antarctic species; 42 specimens; eurybathic, most abundant between 200 and $300 \mathrm{~m}$ depth. Salinity range from 33.5 to $35.6 \%$; temperature range from 7 to $26^{\circ} \mathrm{C}$. Only rare specimens were taken in the extremes of low salinity and high temperature; tolerant of $0.8 \mathrm{ml} / 1$ or lower dissolved oxygen content. Found in BBSW (only one specimen), BBSSW, IOCW, ASIW, SCSW, EIW, AIW, IOSTropSW. Most frequent in colder waters at intermediate depths.

Earlier records include the Antarctic Ocean; a widely distributed species in deep and intermediate depths, almost as far as the Arctic, not recorded from the Mediterranean Sea (Kramp, 1965).

12. Aeginura grimaldii Maas, 1904, Fig. 9. Deep relatively cold waters, not taken in surface waters north of the convergence; 46 specimens; found in deep and intermediate waters and BBSSW. Its limits were 34.9 to $35.4 \%$ salinity, about 6 to $12^{\circ} \mathrm{C}$ and tolerates oxygen content as low as $0.4 \mathrm{ml} /$. Taken in BBSSW, AIW, IOCW, 
ASIW, EIW and deep layers of the Arabian Sea and southern Indian Ocean.

Earlier records show it to be widespread in deep and intermediate layers, except in the Mediterranean and the Arctic (Kramp, 1965); Navas-Pereira (in press) has recorded it from the Antarctic.

13. Cunina duplicata Maas, 1893. Five specimens from deep and intermediate waters of the Bay of Bengal, Arabian Sea and at the subtropical convergence at $40^{\circ} 54^{\prime} \mathrm{S}-60^{\circ} 01^{\prime} \mathrm{E}$. Salinity tolerance from 34.9 to $35.2 \%$; temperature from 6.7 to $11^{\circ} \mathrm{C}$ and tolerates $0.9 \mathrm{ml} / \mathrm{A}$ dissolved oxygen content. An Antarctic species that spreads north via AIW thence to deep, intermediate and subsurface waters in areas of upwelling. It was also taken in ASSSW.

Earlier records indicate a wide and scattered distribution; probably worldwide in intermediate and subsurface layers, in Antarctic waters and occasionally in areas of upwelling (Kramp, 1959a, 1965).

14. Solmissus marshalli Agassiz \& Mayer, 1902, Fig. 5. Forty specimens, deep, intermediate and occasionally surface waters in all the Indian Ocean as far south as $43^{\circ} 59^{\prime}$ S. Taken in BBSW, BBSSW, ASIW, SCSW and at the boundaries between ASSW and ASSSW, IOCW and AIW, IOSTropSW and IOCW. Frequent in upwelling areas. Taken in 32.9 to $36.7 \%$ o salinity; $10^{\circ} \mathrm{C}$ (or lower) to $27.9^{\circ} \mathrm{C}$ and not less than $0.8 \mathrm{ml} / 1$ dissolved oxygen.

Earlier records indicate extensive vertical as well as horizontal distribution in warm and temperate waters (Kramp, 1965).

15. Pegantha clara Bigelow, 1909, Fig. 8. Twenty one specimens. Though it is now known from the Antarctic (Navas-Pereira, in press), it was considered so far to be a surface water species; taken in ASSW, BBSW, SCSW, ASSSW, salinity 34.7 (or lower) to $35.5 \%$; temperature 15.8 (or lower) to $24.5^{\circ} \mathrm{C}$ (or higher), does not seem to tolerate dissolved oxygen content lower than $1.7 \mathrm{ml} / 1$. Taken in the Bay of Bengal and in the Arabian Sea at $29^{\circ} \mathrm{S}$. An eurytopic species.

Earlier records are from the three great oceans, between $40^{\circ} \mathrm{S}$ and 40 to $50^{\circ} \mathrm{N}$, mainly in upper layer waters (Kramp, 1965).

16. Pegantha martagon Haeckel, 1879, Fig. 10. Common, 932 specimens, taken in ASSW, ASSSW, BBSW, IOCW and IOEW. Ninety percent of the specimens come from a surface haul in the Gulf of Aden where aggregates of other species of hydromedusae were also found. This swarm was taken in $36 \%$ salinity, $24^{\circ} \mathrm{C}$ temperature and $4.6 \mathrm{ml} / 1$ dissolved oxygen content. An euryhaline and eurythermal species.

Earlier records are from the upper layers of the three great oceans as far north as $40^{\circ}$ and as far south as the Antarctic continent (Kramp, 1965; Navas-Pereira, in press).

The two last mentioned species, namely $P$. clara and $P$. martagon are not true Antarctic or deep water species. They are included in this group because they could be found in cold and deep waters due to their euryhaline and eurythermic properties. They are mentioned here also to illustrate the fact that any holoplanktonic eurytopic species that comes in contact and adapts to the environmental conditions of the IOCW mass are liable to be widely disseminated. These ubiquitous species are not useful as biological indicators of water masses but mav be useful to indicate mixture of different water masses.

\section{Intermediate waters' species}

17. Tetrorchis erythrogaster Bigelow, 1909. First recorded in the Indian Ocean by Navas (1971). Eight specimens, seven from the mouth of the Gulf of Aden in a haul from $250 \mathrm{~m}$ to surface and one specimen in a haul from $1000-500 \mathrm{~m}$ in the southern Indian Ocean. Probably widespread in deeper layers; tolerates salinity up to $35.6 \%$ and up to $15^{\circ} \mathrm{C}$ temperature and low oxygen content. Its presence may be an indicator of upwelling. Navas (1971) discusses earlier records that suggest this to be a deep and intermediate waters species.

18. Merga reesi Russell, 1956. A single specimen taken in BBSSW, 34.9 to $35 \%$ salinity, 5.8 to $9.8^{\circ} \mathrm{C}$ temperature and 0.5 to $0.8 \mathrm{ml} / /$ dissolved oxygen content. First recorded in the Indian Ocean by Navas (1971). A deep or intermediate water species earlier found in the English Channel in the same salinity and temperature interval, at great depth; a long lived meroplanktonic species.

\section{Eurytopic species}

19. Aequorea pensilis (Eschscholtz, 1829), Fig. 11. Eighty seven specimens, mostly from the Bay of Bengal. It was taken in BBSW, IOCW and at the boundary between BBSW, ASSW and the respective subsurface water masses. Eurythermal and euryhaline; taken in 33 to $36 \%$ ( or higher) salinity, 13.9 (or lower) to $27.4^{\circ} \mathrm{C}$ but may have high oxygen requirements; it was taken as far south and far from land as $30^{\circ} 34^{\prime} \mathrm{S}-69^{\circ} 55^{\prime} \mathrm{E}$, which indicates this to be a long lived meroplanktonic species.

Earlier records are from the Indo-West Pacific region (Kramp, 1968).

20. Protiara tropica Bigelow, 1912, Fig. 2. First recorded for the Indian Ocean by Navas (1971); fourteen specimens. Found in BBSW, ASSW, ASSSW, SCSW and at the surface in upwelled ASSSW. It was found in 32.2 (or lower) to $35.6 \%$ (or higher) salinity, in 20.2 to $26.2^{\circ} \mathrm{C}$ (or higher) temperature and 3.2 to $5.5 \mathrm{ml} / /$ dissolved oxygen content. A coastal shallow water euryhaline and eurythermal species with high oxygen requirements.

Earlier findings from the Philippines, Kei Islands and Sunda Strait are from a similar environment (Navas, 1971).

21. Merga violacea (Agassiz \& Mayer, 1899). Nine specimens from BBSW, BBSSW, ASSSW, SCSW. It was found in 33.4 (or lower) to $35.8 \%$ o salinity; 17 to $29.2^{\circ} \mathrm{C}$ temperature; 0.2 to $5.3 \mathrm{ml} / \mathrm{l}$ dissolved oxygen. It seems to be well adapted to surface and subsurface waters and is probably a long lived species. Its scarcity in this collection is probably due to sampling bias; it may form seasonal swarms and is a meroplanktonic species.

Earlier records show it to have a wide, though scattered distribution in all tropical and subtropical seas (Kramp, 1968).

22. Zanclea orientalis Browne, 1916, Fig. 2. Twenty five specimens; taken in BBSW, IOSTropSW and ASSSW, at the boundary with underlying BBSSW and IOCW or at the 
boundary with overlying ASSW. Avoids high salinity and relatively cold waters. Salinity interval was found to be 32.2 to $35.6 \%$ and temperature 19.0 to $29.4^{\circ} \mathrm{C}$ or perhaps as low as $15^{\circ} \mathrm{C}$, usually found in temperature higher than $20^{\circ} \mathrm{C}$; may tolerate $0.6 \mathrm{ml} / \mathrm{h}$ dissolved oxygen but prefers waters with $4.0 \mathrm{ml} / 1$ or higher. A warm water species that tolerates higher salinities and colder temperatures of boundary layers between tropical waters and adjacent cold waters.

Earlier record is also from the Indian Ocean (Browne, 1916).

23. Vannuccia forbesi (Mayer, 1894). Seven specimens; euryhaline, eurythermal with wide range of dissolved oxygen tolerance. Salinity range from 33.0 to $35.9 \%$; temperature tolerance from $16.0^{\circ} \mathrm{C}$ or lower to $27.4^{\circ} \mathrm{C}$ and oxygen tolerance from 0.8 to $5.1 \mathrm{ml} / \mathrm{l}$. Found in BBSW, BBSSW, ASSSW, SCSW, IOSTropSW and perhaps also in IOCW. It seems to require waters rich in smaller zooplankton for food.

Earlier records show it to be a coastal water species (Kramp, 1961a), also found for the first time in coastal waters with subantarctic influence, off the southern coast of Brazil (Navas-Pereira, 1980, 1981).

24. Pegantha laevis Bigelow, 1909, Fig. 8. Twenty eight specimens; a surface layer species. Taken in BBSW, IOEW, SCSW, not found in the Arabian Sea. Taken as far south as $29^{\circ} 29^{\prime} \mathrm{S}$ in SCSW. Salinity tolerance from 33.8 to $35.6 \%$ with optimum apparently at $35 \%$ or higher salinity; 18.8 to $24.4^{\circ} \mathrm{C}$ temperature and oxygen rich waters.

Earlier records show it to be widespread but not very common; warm and temperate waters, mainly in upper layers (Kramp, 1965).

\section{Arabian Sea and Bay of Bengal species}

These are stenohaline and stenothermal species that exclude each other in the two seas because of the salinity and temperature characteristics of surface and subsurface waters. Salinity and temperature are high in the Arabian Sea and salinity is much lower in the Bay of Bengal. Only one species was found exclusively in the Arabian Sea, while 15 were taken exclusively in the Bay of Bengal, all of them meroplanktonic species.

25. Ectopleura sacculifera Kramp, 1957. Newly recorded for the Indian Ocean by Navas (1971), five specimens; ASSSW in the discontinuity layer off the Arabian coast and in the Gulf of Aden; stenohaline. Found in 35.5-35.9\% salinity, 15.1 to $17.2^{\circ} \mathrm{C}$ (or higher) temperature and 0.2 to $0.6 \mathrm{ml} / 1$ (or slightly higher) dissolved oxygen content.

Earlier record is from the Eastern Pacific Ocean, coast of Ecuador (Kramp, 1957) under a slightly lower salinity interval. It could be a species restricted to upwelling areas. The different environmental requirements of the populations sampled could indicate divergent adaptation as has already been shown to occur in rare species with geographically widely separated stocks (Vannucci, 1966).

The following 15 species were found exclusively in the Bay of Bengal, all of them meroplanktonic:

26. Euphysora annulata Kramp, 1928. Six specimens from a shallow haul $(60-0 \mathrm{~m})$ near the western coast of Thailand in BBSW; 33.1 to $33.8 \%$ salinity, 26.2 to $28.4^{\circ} \mathrm{C}$ temperature and 2.3 to $4.4 \mathrm{ml} / \mathrm{l}$ dissolved oxygen. A shallow water coastal species.
Earlier records include NE Australia, one specimen at 24.1 ${ }^{\circ} \mathrm{C}$ temperature (Kramp, 1953); Sunda Strait (Kramp, 1928) and Madras (Menon, 1932).

27. Koellikerina octonemalis (Maas, 1905); Fig. 2. Twenty specimens. First recorded in the Indian Ocean by Navas (1971). Found only in the eastern part of the Bay of Bengal, in BBSW, BBSSW or at the boundary between the two. The salinity interval was from 33.1 (or lower) to $34.7 \%$, never higher than $35 \%$. It was taken at 16 (or lower) to $26.8^{\circ} \mathrm{C}$ temperature. It probably prefers temperatures higher than $20^{\circ} \mathrm{C}$ and about $4 \mathrm{ml} / 1$ oxygen content. It seems capable of tolerating values as low as 0.8 $\mathrm{ml} / \mathrm{l}$ dissolved oxygen; eurybathic.

Earlier records only from the Malay Archipelago (Maas, 1905; Kramp, 1968).

28. Amphinema rugosum (Mayer, 1900);Fig. 2; twenty five specimens, all in BBSW, or at the boundary between surface and subsurface waters. The upper salinity tolerance limit is about $35 \%$ and can tolerate as low as $33.4 \%$ salinity or even lower. It tolerates up to $29.2^{\circ} \mathrm{C}$ or higher temperature, down to $27^{\circ} \mathrm{C}$ or lower.

Earlier records show it to be widely distributed in subtropical and temperate waters (Kramp, 1959a, 1968).

29. Amphinema dinema (Péron \& Lesueur, 1809). Three specimens taken in BBSW or at the boundary between BBSW and BBSSW. Salinity limits were 33 to $34.8 \%$, temperature limit not higher than $29^{\circ} \mathrm{C}$ but surely higher than $25.8^{\circ} \mathrm{C}$. It perhaps tolerates lower temperature. It can certainly live in dissolved oxygen content of 3.8 to 4.4 $\mathrm{ml} / \mathrm{L}$.

Widely distributed in temperate and subtropical waters (Kramp, 1959a, 1968), considered as a good indicator of coastal waters (Vannucci, 1957, 1963).

30. Pandeopsis scutigera Kramp, 1959, first recorded in the Indian Ocean by Navas (1971); twenty four specimens all from BBSW, salinity 32.7 or lower to $34.5 \%$; temperature from 26 to $29^{\circ} \mathrm{C}$ and oxygen content higher than $3.5 \mathrm{ml} / 1$.

Earlier records confirm this to be a shallow water, low salinity, high temperature species (Navas, 1971).

31. Laodicea indica Browne, 1905; Fig. 11. Fifty one specimens all from the Bay of Bengal, plus eight undetermined Laodicea specimens that may belong to the same species. All come from BBSW and from the boundary with subsurface waters. Salinity always lower than $35 \%$ o and as low as $33 \%$; temperature as high as $29.2^{\circ} \mathrm{C}$ and high oxygen content. It forms swarms.

Earlier records show it to be distributed in the Indo-West Pacific region (Kramp, 1965), older specimens are caught in deeper layers.

32. Halistaura bruuni Navas, 1969; Fig. 13; first described from the Bay of Bengal; thirteen specimens were taken at the discontinuity layer between BBSW and BBSSW (Navas, 1969).

33. Lovenella cirrata (Haeckel, 1879). First recorded in the Indian Ocean by Navas (1971). Five specimens taken in BBSW in 32.9 to $33.4 \%$ o salinity; 29.2 to $29.8^{\circ} \mathrm{C}$ temperature and 4.5 to $4.6 \mathrm{ml} / \mathrm{l}$ dissolved oxygen. Navas (1971) pointed out the difference in environmental requirements of the populations of this species in the Bay of Bengal as compared to those living in the Mediterranean and off south Brazil (Vannucci, 1957).

34. Octophialucium indicum Kramp, 1958. Sixty nine specimens all from BBSW, sixty six of them at a single 
station. A surface layer species found in 31.9 to $33.2 \%$ salinity, 26 to $29^{\circ} \mathrm{C}$ temperature and oxygen content higher than $3.3 \mathrm{ml} / \mathrm{l}$.

35. Phialucium carolinae (Mayer, 1900), Fig. 11. Thirty eight specimens from BBSW or boundary between BBSW and BBSSW. Salinity range 32.8 or lower to $35 \%$; temperature from 20.3 to $29.3^{\circ} \mathrm{C}$ (or higher) and high oxygen content.

Earlier records show this species to be widely distributed in tropical waters (Kramp, 1959a, 1968), found mainly in the Indo- Pacific. The number of radial canals may vary (Kramp, 1953 and present collection); this aspect was discussed in detail by Navas- Pereira (1984a).

36. Phialucium multitentaculatum Menon, 1932. Nine specimens all from BBSW; salinity 33.0 or lower to $34.3 \%$; temperature 25.8 to $29^{\circ} \mathrm{C}$ and oxygen content higher than $3.0 \mathrm{ml} / \mathrm{l}$. A surface layer species.

Earlier records are only from the Indian Ocean and Gulf of Tonkin (Menon, 1932).

37. Eirene elliceana (Agassiz \& Mayer, 1902). First recorded in the Indian Ocean by Navas (1971); five specimens, all from hauls that traversed the boundary layer between BBSW and BBSSW or where there was presence of mixed subsurface waters. Salinity range lower than $35.0 \%$ down to about $33.0 \%$ or lower; temperature from 18 to about $26^{\circ} \mathrm{C}$ or lower.

As shown by Navas (1971), earlier records confirm this to be a subsurface species.

38. Eirene hexanemalis (Goette, 1886); Fig. 8. Twelve specimens, two from BBSW and the others from the discontinuity layer between BBSW and BBSSW. Always taken in salinity lower than $35 \%$ down to $34.1 \%$ or lower; temperature up to $23.7^{\circ} \mathrm{C}$ or higher. The range of dissolved oxygen tolerance may be wide. It probably aggregates at the lower boundary of the surface waters. A specimen taken in 32.2 to $32.7 \%$ salinity and 28.3 to $28.9^{\circ} \mathrm{C}$ was a doubtful specimen, perhaps dead when taken.

Earlier records are from the Indo-West Pacific region, in coastal waters (Kramp, 1968).

39. Aequorea coerulescens (Brandt, 1838), Fig. 13. Thirty four specimens. A surface water species, usually taken in shallow waters. Salinity range 32.7 or lower to $33.9 \%$ or higher; 25.8 to $28.3^{\circ} \mathrm{C}$ or higher temperature and dissolved oxygen content higher than $3.8 \mathrm{mi} / \mathrm{l}$. A BBSW species.

Earlier records include coastal waters in the tropical Pacific, Indian and South Atlantic oceans (Kramp, 1968).

40. Olindias singularis Browne, 1905 . Seven specimens from BBSW. Ranges from 33.1 to $33.5 \%$ salinity; 27.0 or lower to $28.0^{\circ} \mathrm{C}$ temperature and dissolved oxygen content higher than $3.5 \mathrm{ml} / \mathrm{l}$.

Earlier records are from the Indo-West Pacific region (Kramp, 1968).

\section{Widely distributed species}

41. Liriope tetraphylla (Chamisso \& Eysenhardt, 1821), Fig. 14. The second species in order of abundance, with 7217 specimens counted.

42. Aglaura hemistoma (Péron \& Lesueur, 1809). The most abundant species, with 13047 specimens.

43. Cunina tenella (Bigelow, 1909), Figs 12, 15. First recorded in the Indian Ocean by Navas (1971) where a detailed discussion of the distribution of this species is given; 427 specimens found in 31.9 to $36.6 \%$ salinity; 14.1 to $29.2^{\circ} \mathrm{C}$ temperature and tolerant of oxygen content as low as $0.2 \mathrm{ml} / \mathrm{l}$. It appears to be most abundant at the boundary between surface and subsurface waters, with about $35 \%$ salinity and $20^{\circ} \mathrm{C}$ temperature. Taken in ASSW; ASSSW; BBSW; BBSSW; IOEW; IOSTropSW and SCSW and specially at the boundary between these waters and subsurface layers. Recorded as far south as $29^{\circ} 38^{\prime} \mathrm{S}$.

Earlier records are from the Pacific coast of Mexico (Bigelow, 1909) and the Okhotian Sea (Naumov, 1956).

\section{Indian Ocean Central Water species}

These are the most abundantly represented species, for two reasons: first because of sampling bias since most stations were occupied in the central portion of the ocean; second the IOCW is in a sense at the crossroads of all other systems and all the species that tolerate the IOCW environmental properties, are represented in those waters. Several of the species mentioned below were already referred to when dealing with the other ecosystems. The number in front of the name of the species, refers to the serial order in this paper. Most species are holoplanktonic living in waters distant from the continental shelf.

44. Euphysilla pyramidata Kramp, 1955. Nine specimens; stenohaline, usually found at about $35 \%$ salinity, tolerance range is 34.8 to $36 \%$. Eurythermal, taken between $13^{\circ} \mathrm{C}$ (or lower) to $23^{\circ} \mathrm{C}$ (or higher) temperature; widely tolerant of oxygen content, found in 0.5-0.6 to $4.4 \mathrm{ml} / 1$ dissolved oxygen. Was taken in BBSSW; ASSSW; IOCW; IOSTropSW and may perhaps be living also in ASSW and IOEW; clearly avoids BBSW. Taken in upwelling areas off Saudi Arabia; may be a boundary layer species, distribution regulated by salinity.

Earlier records are from the Gulf of Guinea (Kramp, 1955), west of Madagascar (Kramp, 1965) and in the Arabian Sea off the southern coast of India (Vannucci \& Santhakumari, 1971) in ASSW or ASSSW, or at the boundary between the two.

23. Vannuccia forbesi (see p. 46).

45. Zancleu dubia Kramp, 1959. Five specimens from BBSW or BBSSW, ASSW or ASSSW and IOSTropSW or IOCW. One of the specimens comes from off the coast of Saudi Arabia in upwelled ASSSW. A meroplanktonic species whose presence appears to be linked to the discontinuity layer between surface and subsurface waters where food is abundant and to plankton rich upwelling areas. It was found to live in 34.5 to $35.6 \%$ salinity perhaps as low as $32.9 \%$ and as high as $36 \%$. Temperature range from 15.0 to $20.0^{\circ} \mathrm{C}$ and tolerates dissolved oxygen content as low as 0.4 to $0.5 \mathrm{ml} / 1$. First recorded in the Indian Ocean by Navas (1971) who discusses the present finding and the only earlier record in the Java Sea (Kramp, 1959b).

46. Leuckartiara octona (Fleming, 1823), Fig. 11. Sixty nine specimens recorded, all except three from the Bay of Bengal. Twenty percent of the specimens come from BBSW and only $2.8 \%$ from ASSSW. The remaining $77 \%$ comes from the boundary layer between BBSW and BBSSW, one comes from the boundary between ASSW and ASSSW or from one of the two. Most specimens come 
from salinity lower than $35 \%$ down to $32.8 \% 0$ and perhaps lower. One specimen comes from IOCW or IOEW. The temperature interval is from 12.5 to $13.1^{\circ} \mathrm{C}$; tolerates very low dissolved oxygen content, one specimen was taken in ASSSW with $0.2 \mathrm{ml} / 1$ oxygen; most specimens however were taken in waters with oxygen content higher than 2.8 $\mathrm{ml} / \mathrm{l}$. The three specimens living in the Arabian Sea have apparently become adapted to salinity as high as 35.2 to $35.8 \%$ and lower temperature and oxygen content. Vannucci (1966) showed that widely distributed hydromedusae tend to break up into populations, perhaps subspecies, as in Liriope tetraphylla and Cytaeis tetrastyla that have the capacity to adapt to different environmental conditions. Thus the species may be described as eurytopic while each population or single individual may have restricted limits of tolerance of ecological factors.

Earlier records show Leuckartiara octona to be widely distributed (Kramp, 1968), suggesting that young animals live near to the surface while they sink to greater depths as they become older. This would, in fact, be a significant facilitation for the fertilized eggs to settle as planulae and develop into the hydroid generation. A meroplanktonic species. Its distribution was enlarged to the southwest Atlantic Ocean (Navas- Pereira, 1981).

20. Protiara tropica (see p. 45 ).

21. Merga violacea (see p. 45 ).

47. Heterotiara minor Vanhöffen, 1911, Fig. 2. Twenty seven specimens taken mainly at the boundary between surface and subsurface layers in the Arabian Sea, Bay of Bengal and under IOEW. Found also in BBSW, IOEW and IOCW. Salinity interval was 34.3 to $35.1 \%$, with one specimen from the ASSSW/ASSW boundary with salinity as high as $35.6 \%$; temperature from $12^{\circ} \mathrm{C}$ to $20^{\circ} \mathrm{C}$ or higher; tolerant of low oxygen values, down to $1.2 \mathrm{ml} / \mathrm{l}$ or less. Greatest density in IOCW. Vannucci \& Santhakumari (1971) found it in ASSW.

Previous records from the Indo-West Pacific (Kramp, 1965), most probably caught at boundary layers.

48. Aequorea macrodactyla Brandt, 1835. Thirteen specimens taken at boundary layers. A discontinuity or DSL species. From the extreme north of the Arabian Sea, southwards to $30^{\circ} \mathrm{S}$ far from land and over great depths as well as near shore. A long lived meroplanktonic species. It was taken in 34.8 (or lower) to $35.4 \%$ o salinity; 10.8 or lower to $21.2^{\circ} \mathrm{C}$ (or higher) temperature and appears to require high oxygen content. Taken in BBSW/BBSSW boundary, in upwelling ASSSW, IOCW at the boundary with IOSTropSW, with SCSW and with AIW.

Earlier records show it to be widely distributed in the Indo-Pacific region, but scattered in the Atlantic (Kramp, 1968).

19. Aequorea pensilis (see p. 45).

49. Proboscidactyla ornata (McCrady, 1857), Fig. 13. Thirty five specimens from BBSW, IOSTropSW; ASSW and BBSW at the boundary with subsurface water; IOEW and IOCW, and SCSW and IOSTropSW. Salinity from 32.9 to $35.6 \%$ or higher, with preference for about $35 \%$; tolerates up to $29.2^{\circ} \mathrm{C}$ but prefers temperature lower than 20 to $21^{\circ} \mathrm{C}$ and tolerates down to 13 to $14^{\circ} \mathrm{C}$; tolerates low oxygen content.

Earlier records are all from tropical and subtropical region (Kramp, 1959a, 1968), over the continental shelf and slope.
50. Geryonia proboscidalis (Forskål, 1775). Thirteen specimens in IOCW, IOSTropSW and at the boundary between surface and subsurface waters in the Bay of Bengal, the Arabian Sea, the Equatorial system and as far south as the subtropical convergence. Salinity range from 34.8 to $35.5 \%$; temperature $12.9^{\circ} \mathrm{C}$ or lower to $21.2^{\circ} \mathrm{C}$ or higher; requires high oxygen content, not below 2.9 or 3 $\mathrm{ml} / \mathrm{l}$, usually higher.

Earlier records are from all the tropical and subtropical regions (Kramp, 1959a, 1968), widely distributed in boundary layers.

3. Halicreas minimum (see p. 37).

4. Haliscera racovitzae (see p. 44).

5. Halitrephes maasi (see p. 44).

6. Aglantha elata (see p. 44).

51. Amphogona apicata Kramp, 1957, Fig. 6. Common, 181 specimens, spread over the Indian Ocean in IOCW and the water masses with which it mixes, ASSSW and BBSSW; also in ASSW. Usually taken in the upper boundary of the IOCW or at the lower boundary with AIW. A few specimens come from AIW and very rarely also in ASSW. Salinity range from 34.6 to $36.0 \%$ with optimum at about $35.5 \%$; temperature range from $8^{\circ} \mathrm{C}$ or lower to $24.9^{\circ} \mathrm{C}$, optimum between 10 and $14^{\circ} \mathrm{C}$; taken in 0.3 to $4 \mathrm{ml} / \mathrm{l}$ or higher dissolved oxygen content. Most abundant in the Arabian Sea in ASSSW and at its upper and lower boundaries.

Earlier records are from the Atlantic and Indian Ocean (Kramp, 1959a) with an isolated occurrence in the Pacific (Kramp, 1965); always in deep waters.

7. Colobonema sericeum (see p. 44).

8. Crossota alba (see p. 44).

10. Pantachogon haeckeli (see p. 44).

52. Persa incolorata McCrady, 1857, Fig. 5. First recorded in the Indian Ocean by Navas (1971) who also gives its detailed ecological distribution; 119 specimens at depths greater than $1000 \mathrm{~m}$; most animals were found to live at the boundary layer between surface and subsurface layers. Salinity preference 34.6 to $35.2 \%$ but a few specimens were taken in salinity as low as $33 \%$ and as high as $36 \%$, but were dead when taken. Eurythermal, taken in 12.6 to $26.8^{\circ} \mathrm{C}$ temperature, though six specimens come from $6^{\circ} \mathrm{C}$ or lower and 34.5 to $34.7 \%$ salinity; musi specimens appear to be limited between 19 and $20^{\circ} \mathrm{C}$. Tolerates $2 \mathrm{ml} / \mathrm{l}$ oxygen content and two specimens come from $0.3 \mathrm{ml} / 1$ dissolved oxygen content. Taken in BBSW; BBSSW; ASSSW; IOCW; AIW and at the boundaries between surface and subsurface waters. Main limiting factor appears to be high salinity, therefore it is rare in the Arabian Sea and is more abundant in the Bay of Bengal and even more so in intermediate depths of the southern Indian Ocean, where low temperatures are associated to low salinities.

Earlier records are from the Atlantic (including the Mediterranean) and Pacific Oceans (Kramp, 1959a, 1965). It is considered by most authors as a deep water form, probably eurybathic, in the uppermost $1000 \mathrm{~m}$; eurythermic, but not a warm water species (Kramp, 1959a).

53. Rhopalonema velatum Gegenbaur, 1856, Fig. 14. This is the third most abundant species after Aglaura hemistoma and Liriope tetraphylla, with 5301 specimens; taken in almost all the samples where hydromedusae were present. Euryhaline, taken in 30.4 to $36.0 \%$ salinity, rarely up to $36.6 \%$; the largest number comes from $35 \%$ salinity 
or lower. Eurythermal, was taken in waters ranging from 5.1 to $29.2^{\circ} \mathrm{C}$, though rare under such extreme conditions; tolerates wide range of dissolved oxygen content, down to $0.2 \mathrm{ml} / 1$. Due to its preference for low salinity and temperature between 15 and $20^{\circ} \mathrm{C}$ it is common in the Bay of Bengal and in the southern Indian Ocean, while it is relatively rare in the Arabian Sea and in the Equatorial belt. Most frequent at the boundary layer between surface and subsurface waters; greatest density between 250 and $125 \mathrm{~m}$ depth and the discontinuity layer between surface and subsurface waters. Avoids salinity higher than $35.5 \%$ though it can survive under such conditions; it also avoids temperature lower than 12 to $13^{\circ} \mathrm{C}$ though it can tolerate lower temperatures. It was found in BBSW; BBSSW; ASSW; ASSSW; IOCW; IOSTropSW; SCSW; AIW (rarely).

Earlier records agree with this wide distribution that indicates a wide ecological valence; it occurs in all warm and temperate waters (Kramp, 1959a, 1968).

54. Sminthea eurygaster Gegenbaur, 1856, Fig. 6; 143 specimens taken in 34.7 (or lower) to $35.7 \%$ salinity; temperature from about 11 to almost $20^{\circ} \mathrm{C}$, however it appears to tolerate 6.4 as minimum and $21.8^{\circ} \mathrm{C}$ as maximum temperatures. Tolerant of very low oxygen content, down to $0.2 \mathrm{ml} / \mathrm{l}$. Most abundant in IOCW, also found in BBSW; BBSSW; ASSSW; EIW; SCSW; IOSTropSW. Most abundant at the boundary between surface and subsurface waters. Not found further south than $33^{\circ} \mathrm{S}$.

Earlier records show it as occurring in deep and intermediate layers, in warm and temperate regions (Kramp, 1959a, 1968), which agree with the present findings.

17. Tetrorchis erythrogaster (see p. 45)

11. Aegina citrea (see p. 44)

12. Aeginura grimaldii (see p. 44)

55. Solmundella bitentaculata (Quoy \& Gaimard, 1833), Fig. 14. Fourth species in numerical abundance, 3113 specimens counted. Widely distributed in ASSW; ASSSW; BBSW; BBSSW; IOEW; IOCW; IOSTropSW, but not in intermediate or deep waters. Mainly found in lower strata of surface waters, at the boundary layer. Euryhaline, found in 31.9 to $36 \%$ o salinity; eurythermal with preference for warm waters, taken in 11.4 to $29^{\circ} \mathrm{C}$ temperature, a single specimen may have been taken in $9.4^{\circ} \mathrm{C}$, at a depth of 1000 $500 \mathrm{~m}$ in IOCW. Tolerates oxygen content down to $0.2 \mathrm{ml} /$. It does not appear to be affected by salinity since dense swarms were found in high and low salinity, becomes rare in temperature lower than $15-18^{\circ} \mathrm{C}$ and in low oxygen content waters. Most abundant in surface and subsurface waters.

Earlier records show it to be a very common species in tropical, subtropical or cold waters, it ranges from the Antarctic continent to $40^{\circ} \mathrm{N}$; common also in the Mediterranean (Kramp, 1959a, 1968).

16. Pegantha martagon (see p.45)

56. Pegantha triloba Haeckel, 1879, Figs $5,12,16 ; 57$ specimens mainly from surface waters; taken in ASSW; ASSSW; BBSW; BBSSW; IOEW; IOSTropSW and one specimen perhaps from AIW. Probably most abundant at the boundary layer between surface and subsurface waters. Euryhaline and eurythermal taken in salinity ranging from 32.8 to $36 \%$ and 17.2 to $29^{\circ} \mathrm{C}$. One specimen may have been taken in AIW at about $6^{\circ} \mathrm{C}$ temperature. Found also in low oxygen content of $0.2 \mathrm{ml} / \mathrm{l}$ and as far south as $33^{\circ} \mathrm{S}$.
Earlier records show it to have an extensive vertical distribution in the three great oceans between $30^{\circ} \mathrm{N}$ and $30^{\circ} \mathrm{S}$, exceptionally at $50^{\circ} \mathrm{S}$ in the Atlantic (Kramp, 1965).

57. Cunina frugifera Kramp, 1948, Fig. 5; 60 specimens from the Bay of Bengal, Arabian Sea and tropical Indian Ocean, as far south as $22^{\circ} \mathrm{S}$. Surface layer species more common at the discontinuity layer between surface and subsurface waters. Taken in BBSW; ASSW; IOSTropSW and at the boundaries with underlying waters, the BBSSW, ASSSW and IOCW respectively. The limits of tolerance found were 33.4 to $36 \%$ a salinity; 21.1 (or lower) to $25.2^{\circ} \mathrm{C}$. It appears to require high oxygen content.

Earlier records indicate that it is a widely distributed species in surface layers and warm waters (Kramp, 1965).

58. Cunina octonaria McCrady, 1857, Fig. 10; 496 specimens were taken. A widely distributed surface water species, taken as far south as $29^{\circ} 18^{\prime} \mathrm{S}$. Found in BBSW; ASSW; ASSSW; IOEW; IOCW; IOSTropSW; SCSW and EIW and at the boundary between surface and subsurface waters. Salinity ranges from 25.4 to $36 \% 0$ and is most abundant in 33 to $35 \%$ salinity; temperature ranges from 14.1 (perhaps as low as 9.3 ) to $28.8^{\circ} \mathrm{C}$ or higher, most abundant in temperature higher than 19 to $20^{\circ} \mathrm{C}$. Tolerates dissolved oxygen as low as $0.8 \mathrm{~m} / /$ but is usually found in waters with about $3 \mathrm{ml} / 1$ or higher dissolved oxygen content. Appears to have high food requirements.

Earlier records confirm this to be a widely distributed frequent species in warm waters (Kramp, 1965).

59. Cunina peregrina Bigelow, 1909, Fig. 10; 132 specimens from the Bay of Bengal, Arabian Sea and Equatorial Indian Ocean. Found in BBSW; BBSSW; ASSW; ASSSW; SCSW; and in IOSTropSW at the boundary with IOCW. Most abundant in the upper layer and in subsurface waters while $C$. octonaria is most abundant in the lower level of the surface water mass. Its salinity optimum is higher than that of $\mathrm{C}$. octonaria. Salinity tolerance from 31.9 to $36 \%$, optimum about $35.5 \%$. It appears to avoid salinity above $36 \%$; eurythermal, with a range from 12.6 to $29.2^{\circ} \mathrm{C}$ temperature with optimum around or below $20^{\circ} \mathrm{C}$. Found in as low as $0.2 \mathrm{ml} / 1$ dissolved oxygen content.

Earlier records show it to be a widely distributed species in equatorial, tropical and subtropical latitt.des (Kramp, 1965).

14. Solmissus marshalli (see p. 45)

\section{Equatorial system species}

60. Euphysora bigelowi Maas, 1905, Fig. 2; 25 specimens; taken over shallow depths except when carried by currents, as off the Somali coast. Euryhaline high temperature species; most abundant at 33.1 to $33.2 \%$ salinity, tolerant of a range from 31.9 to $35.8 \%$ or $36 \%$; optimum temperature at about $28.0^{\circ} \mathrm{C}$, but found in a, ange from at least 24.0 to $28^{\circ} \mathrm{C}$; apparently high oxygen requirements, not lower than $3.5 \mathrm{ml} / 1$ dissolved oxygen. Taken in the Bay of Bengal in BBSW and off the. Somali coast in upwelled ASSSW mixed with ASSW.

Earlier records show it to be widely distributed in the equatorial and tropical areas of the Pacific and 
Indo-Malayan region, also in coastal areas of Japan and China (Kramp, 1961a).

22. Zanclea orientalis (see p. 45 )

61. Zancleopsis tentaculata $\mathrm{Kramp}, 1928$; five specimens, one of them doubtful. Two specimens taken in BBSW with 33.8 to $34.7 \%$ salinity and 23.4 to $30^{\circ} \mathrm{C}$. Two specimens found in IOEW or IOCW or at the boundary between the two indicate that it may tolerate lower temperature and higher salinity. In either case the dissolved oxygen content was higher than $1.7 \mathrm{ml} / \mathrm{l}$. First recorded in the Indian Ocean by Navas (1971) who mentions earlier records in the West Pacific (Kramp, 1965).

62. Cytaeis tetrastyla Eschscholtz, 1829, Fig. 14, 1823 specimens. It does not seem to be related to the DSL or other boundary areas and it was found in ASSW; ASSSW; BBSW; BBSSW; IOEW; IOCW; IOSTropSW; SCSW; ASIW and perhaps also AIW. Found as far south as the subtropical convergence.

Earlier records agree with these findings (Kramp, 1959a, 1961a, 1968).

63. Bougainvillia fulva Agassiz \& Mayer, 1899; Fig. 11; 36 specimens in BBSW and SCSW. A surface water species tolerant of salinity range from 33.1 to 35.5 or $35.6 \%$; eurythermal, found in a range of $20.8^{\circ} \mathrm{C}$ (or lower) to $26.8^{\circ} \mathrm{C}$ (or higher) temperatures, optimum from 22 to $26^{\circ} \mathrm{C}$; usually taken in waters with $4.0 \mathrm{ml} / 1$ or higher but could perhaps tolerate lower oxygen content. Dissolved oxygen requirements may be the limiting factor for this relatively large species usually found in swarms.

Earlier records indicate tropical areas of the Indian and Pacific Oceans (Kramp, 1968).

64. Bougainvillia platygaster (Haeckel, 1879), Fig. 12; about 400 specimens. A surface layer species that aggregates at the boundary with subsurface waters. Euryhaline, taken from 33.1 to $36 \%$ salinity; eurythermal, found in 17.2 (or lower) to $28.0^{\circ} \mathrm{C}$ (or higher) temperature, not tolerant of dissolved oxygen content lower than $2.7 \mathrm{ml} / \mathrm{l}$. Taken in BBSW, ASSSW, SCSW and IOCW. Most abundant in BBSW, indicating preference for high temperature and relatively low salinity. This species has a remarkable capacity for vegetative reproduction of the medusoid generation which explains the formation of swarms in the high seas in a manner similar to Cytaeis tetrastyla that also has high vegetative reproduction capacity, although both have a bottom living hydroid in their life cycle. Recorded at most stations in the Bay of Bengal. Similarly to Cytaeis tetrastyla it has a wide ecological valence however it does not seem to be competitive with C. tetrastyla in low temperature and high salinity; probably it also has comparatively higher oxygen requirements. $B$. platygaster aggregates at the boundary layer while $C$. tetrastyla prefers surface waters.

Earlier records show it to be widely distributed in tropical seas (Kramp, 1959a, 1968). Kramp (1957) also discusses assexual propagation in this species.

65. Pandea conica (Quoy \& Gaimard, 1827); five specimens taken in IOEW; SCSW and IOSTropSW, found living in 34.5 to $35.5 \%$ salinity, $20^{\circ} \mathrm{C}$ (or lower) to $29^{\circ} \mathrm{C}$ temperature and oxygen content not lower than $2.7 \mathrm{ml} / \mathrm{l}$.

Earlier records are from all tropical and subtropical waters, most common in the Mediterranean (Kramp, 1968).
66. Laodicea fijiana Agassiz \& Mayer, 1899; 96 specimens, over $92 \%$ of them at a single station in IOEW, with salinity between 34 and $35 \%$, temperature presumably higher than $25^{\circ} \mathrm{C}$ and high oxygen content.

Although no data are available for the station, these are the values to be expected at that position, $07^{\circ} 57 \mathrm{~S}-42^{\circ} 16^{\prime} \mathrm{E}$, on Dec. 8, 1964.

Otherwise, this species was always taken at the boundary layer between surface and subsurface layers in the Bay of Bengal and in the Arabian Sea; all specimens come from salinity lower than $35 \%$, only one from higher salinity; temperature presumably not lower than 19 to $20^{\circ} \mathrm{C}$ or more and high dissolved oxygen content. Navas (1971) recorded this species for the first time from the Indian Ocean.

67. Eucheilota menoni Kramp, 1959, Fig. 11; 16 specimens from different water masses show it to be euryhaline and eurythermic. Taken in 32.8 (or lower) to $36 \%$ salinity; $22^{\circ} \mathrm{C}$ (or lower) to $28^{\circ} \mathrm{C}$ (or higher) temperature and oxygen content higher than $2 \mathrm{ml} / \mathrm{l}$. Largest numbers from the Gulf of Aden. Taken in BBSW; ASSW; SCSW and in hauls that traversed surface and subsurface layers. A doubtful specimen comes from IOSTropSW at $13^{\circ} 22^{\prime} \mathrm{S}-47^{\circ} 54^{\prime} \mathrm{E}$. Often taken over great depths far from land but appears to be always found in surface waters and to have high oxygen content requirements.

Earlier records include the Indian Ocean and the West Pacific (Menon, 1932; Kramp, 1959b).

68. Eirene viridula (Péron \& Lesueur, 1809), Fig. 11; 76 specimens taken in only five hauls, where it was present in swarm abundance. A surface layer species, eurythermal and euryhaline, taken in BBSW; ASSW (or ASSSW), IOSTempSW and SCSW, from $13^{\circ} 06^{\prime} \mathrm{N}$ to $40^{\circ} \mathrm{S}$ at the subtropical convergence. Salinity range from 34.4 to $36 \%$ or higher; temperature from 12.9 to $26.7^{\circ} \mathrm{C}$ (or higher) and oxygen content always higher than $4.0 \mathrm{ml} / \mathrm{l}$.

Previously recorded from the Atlantic (including the Mediterranean) and Indian Ocean (Kramp, 1961a); could be an Atlantic species that penetrated into the Indian Ocean through the Mediterranean and Suez Canal, as is the case with Neoturris pileata, discussed by Navas (1971), or more probably travelled around South Africa.

69. Aequorea aequorea (Forskål, 1775), Fig. 13; 24 specimens, all except four in the Bay of Bengal. Low salinity species, most specimens from BBSW. Taken in 31.9 to $34.6 \%$ salinity, never higher than $35 \%$; temperature 22 to $27.7^{\circ} \mathrm{C}$, perhaps higher and lower; usually high dissolved oxygen content. Two specimens taken at $04^{\circ} 40^{\circ} \mathrm{S}-65^{\circ} \mathrm{E}$ in a haul that traversed IOEW and IOCW and two specimens taken in the northern Arabian Sea with 35.6 to $35.9 \%$ salinity and 11.8 to $28.4^{\circ} \mathrm{C}$ temperature. Apparently an eurythermal, low salinity species seldom living above $35 \%$ salinity. A long lived species requiring high oxygen content, may be found far from land, though it is a meroplanktonic species.

Earlier records show it as a widely distributed species, more frequently found in temperate waters (Kramp, 1959a, 1968).

48. Aequorea macrodactyla (see p. 48)

19. Aequorea pensilis (see p. 45)

49. Proboscidactyla ornata (see p. 48)

50. Geryonia proboscidalis (see p. 48)

53. Rhopalonema velatum (see p. 48)

15. Pegantha clara.(see p. 45 ) 

24. Pegantha laevis (see p. 46)
58. Cunina octonaria (see p. 49)
59. Cunina peregrina (see p. 49)

\section{Widely distributed and ecologically ill defined species}

70. Zanclea costata Gegenbaur, 1856; eight specimens, one of them doubtful. Salinity tolerance 34.8 to $36.0 \%$, with preference for warm waters with about 24.5 to $25.2^{\circ} \mathrm{C}$ temperature. Oxygen requirements about $4 \mathrm{ml} / \mathrm{l}$; found in ASSW and BBSSW, in IOEW and IOSTropSW. Seems to avoid salinity higher than $36.0 \%$ and lower than $34 \%$ as well as temperature lower than 20.2 or $22.0^{\circ} \mathrm{C}$. Main limiting factor appears to be dissolved oxygen for which it has high requirements. A boundary layer species.

Earlier records show it to be a coastal water species, widely distributed in warm and temperate waters (Vannucci, 1957; Kramp, 1968); it has high dispersion ability due to the vegetative reproduction of the medusoid stage (Navas-Pereira, 1980, 1984b).

71. Zancleopsis gotoi (Uchida, 1927); ten specimens all except one in the Bay of Bengal. The isolated specimen comes from $24^{\circ} 42^{\prime} \mathrm{S}-23^{\circ} \mathrm{E}$ on the African side of the Mozambique Channel. Majority of specimens taken in BBSW or at the boundary with BBSSW; salinity not higher than $35 \%$ and as low as $33 \%$; temperature from $20.0^{\circ} \mathrm{C}$ to $29.2^{\circ} \mathrm{C}$ and oxygen content higher than $4 \mathrm{ml} / \mathrm{l}$. The southern, isolated specimen comes from $35.3 \%$ salinity, 15.6-22.5 $5^{\circ} \mathrm{C}$ temperature and $45 \mathrm{ml} / 1$ dissolved oxygen content, in SCSW.

Earlier records from the western Pacific, Mozambique Channel and near Nicobar Islands (Kramp, 1968).

72. Merga tergestina (Neppi \& Stiasny, 1912). First recorded in the Indian Ocean by Navas (1971); 155 specimens, only two from the southern Indian Ocean, all the others are from BBSW, 32.7 (or lower) to $33 \%$ o salinity; 27.4 to $28.3^{\circ} \mathrm{C}$ (or higher) temperature and 4.5 to $4.7 \mathrm{ml} / 1$ dissolved oxygen. The southern specimens come from IOCW and SCSW and about 35.3\%o salinity, temperature as low as $18^{\circ} \mathrm{C}$ or lower and dissolved oxygen content 2.8 to $2.9 \mathrm{ml} / \mathrm{l}$. As pointed out by Navas (1971) this agrees with earlier records and laboratory rearing experiments (Vannucci, 1960). An eurytopic species that prefers high temperature, low salinity and rather high dissolved oxygen content. Vannucci \& Santhakumari (1971) found it also in ASSW.

73. Heterotiara anonyma Maas, 1905; Fig. 2; seven specimens, one of them doubtful. Two specimens from ASSW, one from BBSW and the other probably near to the boundary between them and sub-surface waters. Salinity always higher than $35 \%$, up to $35.6 \%$ or $36 \%$, temperature from $11.8^{\circ} \mathrm{C}$ (or lower) to $22.0^{\circ} \mathrm{C}$ and dissolved oxygen content from lower than 0.7 to $3.3 \mathrm{ml} / 1$ or higher. A stenohaline, eurythermal species that may tolerate low oxygen content.

Earlier records show it occurring in the tropical region most probably in subsurface waters (Kramp, 1968).

74. Phialidium hemisphaericum (L.); 18 specimens, all but one from the Bay of Bengal. Taken in BBSW or at the boundary with subsurface waters. One specimen was found very far from land over great depth in IOEW or at its boundary with IOCW. All taken in $33.9 \%$ or lower to
$35 \%$ salinity, temperature from 20 to $28^{\circ} \mathrm{C}$ or higher and dissolved oxygen content higher than $2.1 \mathrm{ml} / \mathrm{l}$.

Earlier work (Kramp, 1968) shows it to be a widely distributed species in tropical and subtropical waters; great intraspecific morphological variation as also in Phialucium carolinae, Blackfordia vinginica and other related Leptomedusae.

75. Aequorea conica Browne, 1905, Fig. 13; fifty specimens, all except three from BBSW in shallow waters with 32 to $34.5 \%$ salinity, 23.8 to $27.7^{\circ} \mathrm{C}$ temperature and oxygen content higher than $4 \mathrm{ml} /$. Three specimens were taken at $40^{\circ} 48^{\prime} \mathrm{S}-65^{\circ} 03^{\prime} \mathrm{E}$ in a $1650-0 \mathrm{~m}$ haul over great depth, with IOSTempSW and AIW; salinity 34.6 to $35.1 \%$; 2.8 to $12.9^{\circ} \mathrm{C}$ temperature and 4.2 to $4.9 \mathrm{ml} / 1$ dissolved oxygen content. Distribution may be regulated by tolerance of low temperature, high salinity and high oxygen content.

Earlier records are only from the Indo-West Pacific, mainly in coastal waters (Kramp, 1968).

\section{Species rare in this collection, ecological distribution unclear}

76. Oceania armata Kölliker, 1853. Four specimens in ASSW, 36.0 to $36.4 \%$ salinity, 25.3 (or lower) to $28^{\circ} \mathrm{C}$ temperature and $4.6 \mathrm{ml} / 1$ (or lower) dissolved oxygen content. Found only in the Arabian Sea.

Earlier records show it to be widely distributed in tropical and subtropical waters (Kramp, 1968).

77. Turritopsis nutricula McCrady, 1856. Two specimens taken between 34.4 to $35.0 \%$ salinity; 11.1 (or lower) to $19.2^{\circ} \mathrm{C}$ (or higher) temperature and $4.5 \mathrm{ml} / 1$ or lower dissolved oxygen content. They were probably living in BBSSW and IOCW (one haul from 100 to $500 \mathrm{~m}$ depth at $\left.23^{\circ} 47 \mathrm{~S}-69^{\circ} 05^{\prime} \mathrm{E}\right)$.

Earlier records show it to be widely distributed (Kramp, 1968), mainly in temperate and subsurface waters (Goy, 1979).

78. Podocoryne apicata Kramp, 1959. Four specimens were taken between $250-125 \mathrm{~m}$ and $200-0 \mathrm{~m}$ at two stations, both of them in the high seas less than $3000 \mathrm{~m}$ deep; salinity about $35.1 \%$; temperature from 14.2 to $18.2^{\circ} \mathrm{C}$ and dissolved oxygen content from 0.4 to $2.8 \mathrm{ml} / \mathrm{l}$. Three specimens come from IOCW and one from ASSSW or ASSW.

Specimens of the genus Podocoryne are usually short-lived and the hydroid, known as Hydractinia, is a commensal living on gastropod mollusks; the present finding would indicate that the gastropod lives at great depths. One station (three specimens) was at $06^{\circ} 28^{\prime} \mathrm{S}-55^{\circ} 12^{\prime} \mathrm{E}$, while the second was at $06^{\circ} 51^{\prime} \mathrm{N}-75^{\circ} 02^{\prime} \mathrm{E}$. There is also a remote possibility that the medusae were taken just after liberation from fouling on the ship's hull. This species was first recorded in the Indian Ocean by Navas (1971), who also discusses earlier records (Gulf of Thailand and Java Sea, Kramp, 1959b).

79. ? Podocoryne camea M. Sars, 1846. A single doubtful specimen taken in the Bay of Bengal, in a haul that crossed BBSW and BBSSW. Salinity was from 33.4 to $35.0 \%$, temperature from 13.3 to $29^{\circ} \mathrm{C}$ and dissolved oxygen content 0.1 to $4.0 \mathrm{ml} / 1$. A new record for the Indian Ocean, if determination is correct. 
Earlier records show this species to be rather widely distributed in relatively cold waters, also in upwelling areas, such as the coast of Chile and South Africa (Kramp, 1961a, 1968).

80. ? Podocoryne meteoris Thiel, 1938. Two doubtful specimens were taken in ASSW at 35.9 to $36 \%$ salinity; 24.5 to $25.2^{\circ} \mathrm{C}$ temperature and 3.6 to $4.5 \mathrm{ml} / 1$ dissolved oxygen content, in the Gulf of Aden. Eckart-Schmidt (in litt.) found this species in the Red Sea and the eastern Mediterranean ("Meteor" material during the IIOE) (Eckart-Schmidt, 1973) and ponders whether this species is an immigrant from the Mediterranean Sea through the Suez Canal, an hypothesis that appears to be correct.

It is the first record for the Indian Ocean, a single specimen being hitherto known, described by Thiel from the Cape Verde Islands.

81. Podocoryne minima (Trinci, 1903). A single specimen was taken at the surface, in November, at $10^{\circ} 57$ ' S $-42^{\circ} 46^{\prime} \mathrm{E}$ in IOSTropSW with salinity from 34.5 to $35.3 \%$; temperature between 25 and $28^{\circ} \mathrm{C}$ in summer and 3.6 to $4.8 \mathrm{ml} / 1$ dissolved oxygen content. First recorded in the Indian Ocean by Navas (1971).

Earlier records show it to be an euryhaline and eurythermal species preferring high temperature and low salinity (Vannucci, 1957, 1963; Navas, 1971).

82. Bougainvillia maniculata Haeckel, 1879. One specimen, described as a new record for the Indian Ocean by Navas (1971), taken in IOCW at $09^{\circ} 28^{\prime} \mathrm{N}-54^{\circ} 52^{\prime} \mathrm{E}$. Navas suggests that it may have migrated from the Mediterranean, the only other known area of occurrence, to the Indian Ocean through the Suez Canal.

83. Bougainvillia niobe Mayer, 1894. Only two specimens from the Southern Indian Ocean, $19^{\circ} 24^{\prime} \mathrm{S}-65^{\circ} 30^{\prime} \mathrm{E}$ in a $2600-250 \mathrm{~m}$ haul that filtered AIW, IOCW and IOSTropSW. Salinity range 34.7 to $35.6 \%$ and oxygen content 3.9 to $4.8 \mathrm{ml} /$, wide temperature variation.

Earlier records are all from the western subtropical and temperate Atlantic Ocean (Kramp, 1959a).

84. Bougainvillia ramosa (van Beneden, 1844). Seventeen specimens taken in BBSW with low salinity, high temperature and high oxygen content and may be young stages of $B$. ramosa. They were all found in the Andaman Sea in the Bay of Bengal. None of them were mature and since juveniles of this species are extremely similar to young $B$. platygaster, the present specimens of this short-lived species are only tentatively assigned to $B$. ramosa.

Earlier records show this to be a cosmopolitan species in coastal waters (Kramp, 1968).

85. Koellikerina constricta (Menon, 1932). Four specimens were taken in the Bay of Bengal, two in BBSW and two either in the surface layer or at the boundary between surface and subsurface waters. Salinity interval 33 to $35 \%$ salinity; temperature 25.8 to $27.4^{\circ} \mathrm{C}$, perhaps higher or lower; dissolved oxygen content 3.8 to $4.5 \mathrm{ml} / \mathrm{l}$.

Previously recorded only once, also from the Indian Ocean (Menon, 1932).

86. Koellikerina elegans (Mayer, 1900). A single specimen from BBSW, in 32.7 to $33.5 \%$ salinity; 26.3 to $29.2^{\circ} \mathrm{C}$ and 3.6 to $4.6 \mathrm{ml} / \mathrm{l}$ dissolved oxygen content.

Earlier records are from Florida (Mayer, 1900) and the Indian Ocean (Nair, 1951; Ganapati \& Nagabhushanam, 1958).

87. Koellikerina fasciculata (Péron \& Lesueur, 1809). A single specimen was recorded by Navas (1971) for the first time in the Indian Ocean from the Arabian Sea in 36.0 to $36.44 \%$ salinity in ASSW or ASSSW. Navas suggests that the species may have migrated from the Mediterranean into the Indian Ocean through the Suez Canal. It is otherwise known as an endemic Mediterranean species (Petersen \& Vannucci, 1960).

Earlier records are discussed by Navas (1971).

88. Koellikerina multicirrata (Kramp, 1928). Three specimens were taken in the Bay of Bengal, all of them probably were living at the boundary between surface and subsurface water masses. Not found in salinity higher than $35 \%$.

Earlier records are from tropical waters in the Indo-Pacific region (Kramp, 1968).

89. ? Cirrhitiara superba (Mayer, 1900). A single doubtful specimen from the Bay of Bengal, taken from $125-0 \mathrm{~m}$ in a haul that went through BBSW. Salinity was $34.8 \%$ down to $32.45 \%$. It could be the first record for the Indian Ocean.

Earlier records are from the western Atlantic and North-Eastern Australia (Kramp, 1959a, 1968).

90. ? Halitiara formosa Fewkes, 1882. One doubtful specimen from the Bay of Bengal in a $125-0 \mathrm{~m}$ haul through BBSW and BBSSW; salinity from 32.6 to $34.7 \%$; temperature 19.2 to $29.1^{\circ} \mathrm{C}$ and dissolved oxygen content from 0.7 to $4.5 \mathrm{ml} / \mathrm{l}$.

Earlier records show it to be a tropical water species (Kramp, 1959a, 1968).

91. Leuckartiara gardineri Browne, 1916. A single specimen from the Bay of Bengal in a $125-0 \mathrm{~m}$ deep haul that filtered through BBSW and BBSSW. Salinity from 32.7 to $34.9 \%$; temperature 13.3 to $29.3^{\circ} \mathrm{C}$ and dissolved oxygen content 0.6 to $4.3 \mathrm{ml} / \mathrm{l}$.

Earlier records are also from the Indian Ocean (Browne, 1916; Kramp, 1968) and western Pacific Ocean (Kramp, 1953).

92. ? Leuckartiara zacae Bigelow, 1940. Two doubtful specimens, one from the Bay of Bengal in a $125-0 \mathrm{~m}$ haul that filtered BBSW and BBSSW, and the other from the Arabian Sea, in ASSSW. Salinity not higher than 35.1\%o.

Earlier records are from scattered localities of the IndoPacific region (Bigelow, 1940; Kramp, 1968).

93. Neoturris pileata (Forskål, 1775). A single specimen from ASSSW, in 35.5 to $35.8 \%$ salinity; 12.7 to $14.4^{\circ} \mathrm{C}$ temperature and $0.5 \mathrm{ml} / \mathrm{l}$ dissolved oxygen content. Navas (1971) recorded it for the first time in the Indian Ocean and suggests that this Atlantic species reached the Indian Ocean either around Cape Agulhas or via the Mediterranean through the Suez Canal; the North Atlantic, Mediterranean and Arabian Sea populations, although geographically separated, appear to have maintained similar ecological requirements in relation to the factors considered here.

Earlier records are mainly from the Mediterranean and Atlantic, also the Pacific coast of North America (Kramp, 1959a, 1968).

94. Octotiara nusselli Kramp, 1953. A single specimen taken in BBSW, in 34.0 to $34.2 \%$ salinity; 4.4 to $4.6 \mathrm{ml} / \mathrm{l}$ dissolved oxygen content and 28.6 to $28.9^{\circ} \mathrm{C}$ temperature.

Earlier records are from coastal waters, in the Indo-West Pacific region (Kramp, 1968).

95. Protiara haeckeli Hargitt, 1902. A single specimen earlier referred to as a new record for the Indian Ocean 
(Navas, 1971); taken in BBSW with 33.1 to $33.2 \%$ salinity; 26.2 to $28.9^{\circ} \mathrm{C}$ temperature and 2.0 to $4.4 \mathrm{ml} / \mathrm{l}$ dissolved oxygen. Previously recorded from the West Atlantic (Hargitt, 1902).

96. Stomotoca atra L. Agassiz, 1862. First recorded by Navas (1971), two specimens taken in hauls from BBSW and BBSSW waters; they may have been living at the discontinuity layer between the two.

Earlier records, from the east Pacific, are listed by Navas (1971).

97. Stomotoca pterophylla Haeckel, 1879. Two specimens first recorded in the Indian Ocean by Navas (1971). Both specimens come from hauls that crossed both BBSW and BBSSW.

Earlier records from the Atlantic and East Pacific regions are listed by Navas (1971).

98. Calycopsis papillata Bigelow, 1918. A single specimen taken in the Gulf of Aden, in salinity higher than $36 \%$, haul from $1000 \mathrm{~m}$ depth to surface.

Previously recorded from tropical waters of the Atlantic and west Indian Ocean (Kramp, 1968).

99. Calycopsis simulans (Bigelow, 1909). A single doubtful specimen from a $275-0 \mathrm{~m}$ haul that traversed IOEW and IOCW.

Earlier records are from coastal waters of the tropical Pacific and Indian Oceans (Kramp, 1968).

100. Sibogita geometrica Maas, 1905. Two specimens taken in the southern Indian Ocean, one in the Mozambique Channel and the other in the Central Southern Indian Ocean at $13^{\circ} 57 \mathrm{~S}-65^{\circ} 05^{\prime} \mathrm{E}$. They were found living in IOCW or perhaps in AIW in 34.7 to $35.4 \%$ salinity; 14.6 (or lower) to $16.4^{\circ} \mathrm{C}$ (or higher) in not less than $2.1 \mathrm{ml} / 1$ dissolved oxygen content.

Earlier records are from the Indo-West Pacific and Eastern Atlantic (Kramp, 1968), also taken in intermediate layers.

101. Melicertissa mayeri Kramp, 1959. A single specimen recorded for the first time in the Indian Ocean by Navas (1971), taken in a $500-0 \mathrm{~m}$ haul that traversed ASSW and ASSSW, 35.4 to $35.5 \%$ salinity; 11.2 to $26.8^{\circ} \mathrm{C}$ temperature; 0.8 to $5.0 \mathrm{ml} / 1$ dissolved oxygen.

Recorded previously only by Mayer (1910) in the West Atlantic.

102. Melicertissa orientalis Kramp, 1961. Two doubtful specimens were taken in BBSW with $32.9 \%$ o salinity; $27.8^{\circ} \mathrm{C}$ temperature; $4.7 \mathrm{ml} / 1$ dissolved oxygen content at the surface.

Earlier records are from NE Australia (Kramp, 1961b); if confirmed, this would be a new record for the Indian Ocean.

103. Ptychogena hyperborea Kramp, 1942. A single specimen probably belonging to this species was taken between 746 and $275 \mathrm{~m}$ depth at $06^{\circ} 00^{\prime} \mathrm{S}-65^{\circ} 10^{\prime} \mathrm{E}$, in 34.8 to $35.0 \%$ salinity; 7.3 to $10.8^{\circ} \mathrm{C}$ temperature and 1.7 to 2.7 $\mathrm{ml} / 1$ dissolved oxygen content. The water masses present were IOCW and EIW. A new record for the Indian Ocean, hitherto known only from Greenland (Kramp, 1942) and from Antarctic waters (Navas-Pereira, in press).

104. Staurodiscus tetrastaurus Haeckel, 1879. Two specimens from shallow waters, one in BBSW and the other in SCSW; salinity 34.2 to $34.3 \%$; temperature 27.2 to $28.2^{\circ} \mathrm{C}$ at one station while it was 21.6 to $22.5^{\circ} \mathrm{C}$ at the other; dissolved oxygen content 3.8 to $4.5 \mathrm{ml} / \mathrm{l}$ at one station and 5.2 to $5.3 \mathrm{ml} / \mathrm{l}$ at the other.
Earlier records are given in Kramp (1965), taken in coastal waters in the Atlantic and Indian Oceans, at scattered localities.

105. Toxorchis polynema Kramp, 1959. Three specimens from the Bay of Bengal taken in hauls that filtered through BBSW and upper layer of the BBSSW. Salinity always lower than $35 \%$.

Earlier records are from the Tropical Atlantic (Kramp, 1959a), and the Bay of Bengal, Nicobar Islands (Kramp, 1959b).

106. Toxorchis thalassinus (Péron \& Lesueur, 1902). Two specimens from BBSW; $33.0-33.4 \%$ salinity; 25.2 to $28.8^{\circ} \mathrm{C}$ temperature; 3.8 to $4.6 \mathrm{ml} / 1$ dissolved oxygen content. A new record for the Indian Ocean, the species was described and recorded earlier only from the West Pacific (New Guinea and North Australia). A redescription of this rare species should be made.

107. Toxorchis sp. A new species was found in the Bay of Bengal from BBSW and boundary layer from BBSSW.

108. Obelia spp, an assemblage of species. The genus as a whole is eurytopic, cosmopolitan; 17 specimens taken from BBSW, BBSSW, ASSW and ASSSW and at the boundary between surface and subsurface waters in a wide range of salinity, temperature and dissolved oxygen content.

Earlier records in Kramp (1959a, 1961a, 1968).

109. Phialidium mccradyi (Brooks, 1888). A single specimen taken in 32.8 to $34.7 \%$ salinity; 21 to $28.7^{\circ} \mathrm{C}$ temperature and 0.3 to $4.7 \mathrm{ml} / 1$ dissolved oxygen content in BBSW mixed with BBSSW in the lower layer, a haul $250-0 \mathrm{~m}$ depth. First recorded in the Indian Ocean by Navas (1971).

110. Phialidium simplex Browne, 1902. A single specimen taken in BBSW, salinity 34.2 to $34.8 \%$; 22 to $28.6^{\circ} \mathrm{C}$ temperature and 1.0 to $4.8 \mathrm{ml} / \mathrm{l}$ dissolved oxygen content.

Earlier records are mainly from cold water (Kramp, 1959a), being found also in NE Australia (Kramp, 1953) and Indo-West Pacific region (Kramp, 1965).

111. Cirrholovenia tetranema $\mathrm{Kramp}, 1959 . \mathrm{T}$ wo specimens in BBSW. First recorded in the Indian Ocean by Navas (1971). Earlier records suggest that it is a surface layer species.

112. Eucheilota duodecimalis A. Agassiz, 1862. A single specimen taken in a haul $250-0 \mathrm{~m}$ depth that filtered BBSW and BBSSW. The species was first recorded by Navas (1971) for the Indian Ocean. It was pointed out that salinity and temperature ranges for the species agrce with those earlier recorded from Brazil (Vannucci, 1960, 1963).

113. Eucheilota tropica Kramp, 1959. Three specimens from BBSW, taken in 34.3 (or lower) to $34.4 \%$ (or higher) salinity; 27.2 (or lower) to $28.2^{\circ} \mathrm{C}$ (or higher) temperature; high dissolved oxygen content, around $4.0 \mathrm{ml} / \mathrm{l}$.

Earlier records are from the Indian Ocean and West Pacific (Menon, 1932; Kramp, 1959b, 1962, 1965).

114. Lovenella assimilis (Browne, 1905). A single specimen taken in BBSW in 34.4 to $34.5 \%$ salinity; 26.7 to $28.7^{\circ} \mathrm{C}$ temperature; 4.0 to $4.4 \mathrm{ml} / 1$ dissolved oxygen content.

Earlier records show it to be an Indo-West Pacific species (Kramp, 1968).

115. Phialella falklandica Browne, 1902. A single doubtful specimen in IOEW or IOCW at $03^{\circ} 07 \mathrm{~S}-40^{\circ} 39^{\prime} \mathrm{E}$. 
Previous records are only from cold waters (Kramp, 1959a). It would be a new record for the Indian Ocean.

116. Phialella quadrata (Forbes, 1848). A single doubtful specimen in BBSW with 32.3 to $33.8 \%$ salinity; 26 to $29^{\circ} \mathrm{C}$ temperature; 3.2 to $4.5 \mathrm{ml} / 1$ dissolved oxygen content.

117. Octophialucium bigelowi Kramp, 1955. A single doubtful specimen from BBSW with 33.4 to $34.4 \%$ salinity; 27.7 to $28.9^{\circ} \mathrm{C}$ temperature; 2.0 to $4.8 \mathrm{ml} / \mathrm{l}$ dissolved oxygen. It would be a new record for the Indian Ocean; previously found on both sides of the American Continent, in warm waters (Vannucci \& Soares-Moreira, 1966).

118. Octophialucium medium $\mathrm{Kramp}$, 1955. Two specimens found, one in BBSW, in $33 \%$ salinity; $27.4^{\circ} \mathrm{C}$ temperature and $4.5 \mathrm{ml} / 1$ dissolved oxygen content. The other specimen was found in ASSSW in 35.2 to $35.3 \%$ salinity; 12.3 to $18^{\circ} \mathrm{C}$ temperature; 2.0 to $2.4 \mathrm{ml} / 1$ dissolved oxygen. It thus appears to be an euryhaline and eurythermal species requiring high oxygen content.

Earlier records, according to Kramp (1968), show it to have a scattered distribution near the Equator, from the eastern Atlantic through the Indian Ocean, to the western Pacific.

119. Phialucium condensum Kramp, 1953. A single specimen taken in BBSW in 32.7 to $34.0 \%$ salinity; 24.2 to $28.7^{\circ} \mathrm{C}$ temperature; 2.1 to $4.7 \mathrm{ml} / 1$ dissolved oxygen content, in a haul from $50 \mathrm{~m}$ depth to the surface.

First recorded in the Indian Ocean by Navas (1971) who showed it to be a warm, shallow water species, throughout its geographic range.

120. Eirene brevigona Kramp, 1959. Two specimens taken in the same haul, $200-0 \mathrm{~m}$ in the Arabian Sea, that crossed ASSW and ASSSW. Salinity range 35.2 to $35.5 \%$. Navas (1971) recorded it for the first time from the Indian Ocean.

Earlier records from the Malayan coast (Navas, 1971) were from warm waters and low salinity.

121. Helgicirrha malayensis (Stiasny, 1928). Two specimens from the Bay of Bengal, in surface or subsurface waters; salinity between 33 and $35 \%$; temperature as high as $27.4^{\circ} \mathrm{C}$ and perhaps higher; oxygen content around 4.5 $\mathrm{ml} / \mathrm{l}$.

Earlier records are from the Indo-Pacific region (Kramp, 1968).

122. Helgicirrha medusifera (Bigelow, 1909). First recorded in the Indian Ocean by Navas (1971). Two specimens from the Bay of Bengal in salinity lower than $34.9 \%$ and perhaps as low as $32.9 \%$. In either case the net filtered through BBSW and BBSSW.

Earlier records are from surface waters on the Pacific coast of Mexico and Panama. Vannucci \& Santhakumari (1971) recorded it in the eastern Arabian Sea off the southern Indian coast.

123. Eutima curva Browne, 1905. A single specimen from the Arabian Sea taken in a haul from $250-0 \mathrm{~m}$ that filtered ASSW and ASSSW. The ranges for the water column were 35.4 to $35.7 \%$ salinity; 15.2 to $27.2^{\circ} \mathrm{C}$ temperature; 1.4 to $5.0 \mathrm{ml} / \mathrm{l}$ dissolved oxygen content.

Earlier records are from the Indo-West Pacific region (Kramp, 1968) in coastal waters.

124. Eutima gentiana (Haeckel, 1879). First recorded in the Indian Ocean by Navas (1971). Nine specimens from a single haul at $07^{\circ} 57 \mathrm{~S}-42^{\circ} 16^{\prime} \mathrm{E}$, from $50-0 \mathrm{~m}$ depth. The water mass must have been IOSTropSW, esvironmental data absent.

Earlier record: the Canary Islands (Haeckel, 1879) and a doubtful record from China (Vanhöffen, 1913).

125. Eutima mira McCrady, 1857. First recorded in the Indian Ocean by Navas (1971). Five specimens in the same haul as $E$. gentiana and two more at $05^{\circ} 19^{\prime} S-53^{\circ} 32^{\prime} \mathrm{E}$, also at the surface, probably IOEW. Known to be a high temperature, high salinity, surface species (Vannucci, 1957).

126. Eutima orientalis (Browne, 1905). Two specimens taken in the Bay of Bengal, one in BBSW, 33.1 to $33.2 \%$ salinity; 26.0 to $27.6^{\circ} \mathrm{C}$ temperature; 4.0 to $4.5 \mathrm{ml} / \mathrm{l}$ dissolved oxygen content. The second specimen comes from a $500-0 \mathrm{~m}$ deep haul that filtered through BBSW and BBSSW.

Earlier records indicate that it is a coastal water species, in the Indo-West Pacific region (Kramp, 1968).

127. Aequorea globosa Eschscholtz, 1829. Two specimens from the Bay of Bengal, one in BBSW and one in a haul that filtered both BBSW and BBSSW. Salinity lower than $35.0 \%$; temperature up to $27.7^{\circ} \mathrm{C}$ or higher.

Earlier records from scattered localities in the IndoPacific (Kramp, 1968).

128. Aequorea parva Browne, 1905. Two specimens were taken, one from IOSTempSW at $40^{\circ} 48^{\prime} \mathrm{S}-65^{\circ} 03^{\prime} \mathrm{E}$ perhaps at the boundary with AIW, 34.6 to $35.1 \%$ salinity; 2.8 to $12.9^{\circ} \mathrm{C}$ temperature; 4.2 to $4.9 \mathrm{ml} / 1$ dissolved oxygen content. One specimen taken at $07^{\circ} 57 \mathrm{~S}-42^{\circ} 16^{\prime} \mathrm{E}$ bears no hydrographical data; may have been taken in upwelled waters.

Earlier records show a scattered distribution in the Indo-West Pacific (Kramp, 1968).

129. Amphogona apsteini (Vanhöffen, 1902). A single specimen taken in 36.6 to $37.2 \%$ salinity; 19.6 to $28.9^{\circ} \mathrm{C}$ temperature; 0.6 to $4.9 \mathrm{ml} / \mathrm{l}$ dissolved oxygen content, from a haul $250-0 \mathrm{~m}$ at $22^{\circ} \mathrm{N}-59^{\circ} \mathrm{E}$.

Earlier records show it as an epipelagic species with a scattered distribution, from the east Atlantic to the eastern Pacific, including the Indian Ocean, probably circumglobal (Kramp, 1965).

130. Pantachogon scotti Browne, 1910. Only two specimens from the Arabian Sea at $17^{\circ} 41^{\prime} \mathrm{N}-68^{\circ} 03^{\prime} \mathrm{E}$, at depth not greater than $1000 \mathrm{~m}$, taken on March 3rd, 1963. Salinity about $35.5 \%$; 11.9 to $14.5^{\circ} \mathrm{C}$ temperature; 0.1 to $0.2 \mathrm{ml} / 1$ dissolved oxygen content. These specimens could have come from ASSW, ASSSW or ASIW.

Earlier records are only from the Antarctic (Kramp, 1959a).

131. Solmaris rhodoloma (Brandt, 1838). Only one specimen. First recorded in the Indian Ocean by Navas (1971), who also comments on earlier findings. It was taken in a haul that filtered both BBSW and BBSSW, in the Bay of Bengal in 31.7 to $35 \%$ salinity; 11 to $28.2^{\circ} \mathrm{C}$ temperature; 0.1 to $4.9 \mathrm{ml} / \mathrm{l}$ dissolved oxygen.

\section{Discussion}

Ecological distribution of the Hydromedusae taken during the IIOE

Roughly 45,000 specimens were studied. They belong to 131 different species; 59 of them are represented by less 
than five specimens and are not shown on Table 2. Some of these are rare species everywhere, such are Podocoryne meteoris, Bougainvillia maniculata, Leuckartiara zacae, Toxorchis thalassinus, and others. However, most of the rare species of this collection, are so because of a sampling bias due to the fact that most stations were occupied in the open ocean over great depths and only a very small percentage was occupied over the shelf or nearer to the coast. Thus, meroplanktonic species are poorly represented. Three of the rare species are considered to be Mediterranean immigrants into the Indian Ocean, which may have travelled through the Suez Canal and Red Sea. They are Podocoryne meteoris, Bougainvillia maniculata, Koellikerina fasciculata. Two other rare species also appear to be immigrants, but in either case it seems more likely that they reached the Indian Ocean by way of the Cape of Good Hope, viz Neoturris pileata and Bougainvillia niobe.

It is significant that the great majority of the species poorly represented in this collection were taken in the surface layer of the Bay of Bengal. These waters have a high temperature and low salinity and are in this sense comparable to coastal waters at low latitudes, although they are oceanic in the sense that they occur far from land and are deep.

Conversely, the very great majority of specimens taken belong to oceanic species again due to the same sampling bias that was introduced by the geographical position of the stations. Over $61 \%$ of the specimens taken belong to four species that, significantly, are holoplanktonic and have no fixed hydroid in their life cycles. The four species are: Aglaura hemistoma, with almost $29 \%$ of the specimens taken; Liriope tetraphylla, with almost $14 \%$; Rhopalonema velatum with almost $12 \%$ and Solmundella bitentaculata with almost $7 \%$.

Another sampling bias introduced during sampling at sea refers to depth, as the number of stratified samples that were taken with closing nets decreases with depth and bottom water samples were not taken. Nonetheless, the number of specimens belonging to Antarctic and sub-Antarctic species whose dispersal is temperature-controlled was relatively great and shows that cold water dependent species spread north even beyond the northern limit of the AIW mass that has its northern limit at roughly $10^{\circ} \mathrm{S}$ lat. Intermediate and deep water species are by and large the same in the Arabian Sea as in the Bay of Bengal, but a few were found so far only in one of the two seas. The main discriminating ecological factors are probably the higher salinity and the very low or nil oxygen content at the oxygen minimum layer in the Arabian Sea.

About one quarter of the species taken have a distribution showing a clear aggregation at the boundary layer, whether between surface and subsurface layers, at deeper levels or at the surface, along fronts.

One amazing finding refers to the great number of species and specimens that were found to be living in water with very low oxygen content and were healthy and normal, so far as can be judged from the preserved specimens. Hydromedusae have a low metabolism in relation to total body weight (Buddenbrock, 1952; Schmidt-Nielsen, 1990) and this may be a factor favouring these species when compared to others with higher oxygen requirements. Many species and many specimens were found to tolerate and live in waters with as low or lower oxygen content than $0.2 \mathrm{ml} / \mathrm{l}$ dissolved $\mathrm{O}_{2}$, even when they were not restricted to the oxygen minimum layer. Fraser (1969) quotes a high conversion factor of $37 \%$ for medusae and this may be related to their capacity to endure unfavourable surroundings. More precise and finer methods of analysis of ecological distribution and more detaileci sampling at sea may provide more precise information as discussed by Vinogradov \& Voronina (1962).

Finally the study of the distribution of closely related species, such as congeneric species, shows tinat (Table 2) in no case their distribution is controlled by the same factors. Thus in the genus Zanclea, one species, $Z$. costata is stenohaline, stenothermal and has strict oxygen requirements, while the distribution of anoti er, $Z$. dubia, is regulated by high food requirements and a third one, $Z$. orientalis, that also has high food requirements, is found in different water masses from $Z$. dubia. Similar observations can be made for all the other genera that were represented by more than one species. The genus Eirene appears, from the table, to be an exception, since both $E$. ellicean $a$ and $E$. hexanemalis are stenohaline, found only in the Bay of Bengal and at the boundary layer. However, E. elliceana seems to prefer lower salinity and is tolerant of lower temperature, while $E$. brevigona from the Arabian Sea prefers higher salinity and $E$. viridula is found in the Bay of Bengal, in the Arabian Sea and in the Tropical Equatorial System being widely tolerant of different salinities and temperatures.

Also in the genus Cunina, C. peregrina and C. octonaria appear to have the same distribution, but the latter seems to have its optimum at lower salinity $(33-35 \% 0)$ and at $19^{\circ} \mathrm{C}$ to $20^{\circ} \mathrm{C}$ temperature, while $C$. peregrina replaces it at 35.5 to $36 \%$ salinity and $20^{\circ} \mathrm{C}$ or lower temperature, the marked difference between the two, however, is that $C$. peregrina is found in as low as $0.2 \mathrm{ml} / / \mathrm{O}_{2}$ while $C$. octonaria was not taken below $0.8 \mathrm{ml} / 1 \mathrm{O}_{2}$ and it is usually found to have higher oxygen requirements. This determines their respective ecological niches.

Many other examples could be given but they may easily be deduced from the text for each species and from the tables. They show clearly how plankton species are maintained separated by ecological mechanisms, especially closely related species, even if they are geographically and temporally sympatric. Hutchinson (1959) discussed how the larger the number of species the greater becomes the stability of the ecosystem and also how a group containing many diversified species will be able to seize new evolutionary opportunities more easily than an unidentified group. Margalef $(1957,1968,1982)$ also has repeatedly demonstrated the same point.

According to the principle first enunciated by Volterra (1926) and later developed by Gause (1934), different species cannot share indefinitely the same ecological niche since one of them will eventually and inevitably be displaced by the other. The results of the present work show again that even at a gross level the optima for different ecological factors do not coincide in separate species, consequently at every time interval, however small, one species will be favoured against the others. Considering that developmental stages may have different requirements and that conditions in the surface and subsurface layers of the oceans are continuously changing, no species in a given water mass will be favoured for a very 
long time and it will not have time to displace others. Successively and at alternate times, most or all of the species will find their optima and are in turn favoured; by this mechanism many different species may coexist for a long time in a single body of water. The rate of variability of environmental conditions, whether quick or slow becomes an ecological factor of importance since the adaptive capacity both physiological and selective of the species must be tuned to it; in this sense the time factor acquires the value of an ecological niche.

The study of Antarctic Ocean hydromedusae (Navas-Pereira, in press) shows clearly how different species spread northwards with Antarctic Intermediate Water. The species however reach different distances from the convergence according to their ecological valence, since AIW gradually changes by mixing and is finally replaced by other water masses. In an earlier paper, Vannucci (1966) compared the ecological valence of the conspecific populations from the Gulf of Naples and from the southern Brazilian coast. She showed that widely distributed species were in both places at about the same intervals for the ecological factors considered (temperature and salinity) while the sparsely distributed species appear to have broken up into distinct populations more closely adapted to local conditions, as a probable result of geographical isolation. The comparison of the ecological valence in the Indian Ocean, South Atlantic Ocean (off south Brazil) and Mediterranean shows that, for the species that occur in all three areas, Cytaeis tetrastyla, Proboscidactyla omata, Rhopalonema velatum and Solmundella bitentaculata have the same salinity preferences but different temperature intervals in the three regions. The four of them are widely distributed in warm waters and are either holoplanktonic or have vegetative reproduction. Phialidium hemisphaericum is coastal and meroplanktonic, showing the same temperature intervals in the three regions, but the Mediterranean population appears to be adapted to somewhat higher salinity. Liriope tetraphylla and Aglaura hemistoma are the most widely distributed species; they are euryhaline and eurythermal and the former shows salinity and temperature optima different in the three regions, while the data for $A$. hemistoma show differences in salinity preferences but are not clear for temperature preferences of different populations.

\section{Geographical distribution}

Geographic distribution of hydromedusae has been the subject of several studies, mainly by Kramp (1959a, 1961, 1968) who summarized all the information available in his Monographs on the Atlantic and Indo-Pacific Hydromedusae and in his Synopsis of the Medusae of the World. Studies on the distribution of hydromedusae in relation to environmental factors, mainly salinity, temperature and dissolved oxygen content were carried out by Vannucci $(1957,1963,1966)$, Vannucci, Santhakumari \& Santos (1970), and Navas-Pereira (in press). Studies of the geographic distribution of plankton organisms have a restricted value when only the geographic coordinates of the stations are considered and not the depth of haul and environmental parameters. Environmental conditions in the oceans vary drastically with depth while the same salinity, temperature, oxygen content and other ecological factors are approximately the same over very extensive horizontal geographic areas, specially in intermediate and deep waters. It thus appears more reasonable to study the patterns of distribution in relation to water masses and other oceanographic phenomena rather than in relation to geographic coordinates alone.

Early studies, mentioned above, on geographic distribution of hydromedusae revealed some patterns and Arctic, Antarctic, temperate, tropical, Atlantic, Mediterranean or Indo-Pacific faunae of medusae were described. However, as more data were gathered and as more and more hitherto unsampled areas were studied, the gaps gradually were filled in and the boundaries between so called geographic regions became more and more blurred, while the ecological distribution of most species has become more and more evident. Similar ideas guided Bary $(1963 \mathrm{a}, \mathbf{b})$ in his studies of plankton distribution in relation to environmental factors, and led him to construct the T-S-P diagram.

The geographic distribution of species is originated by geological and evolutionary phenomena that act on plankton organisms as much as on other organisms, but differently from land animals, the plankton is distributed along a worldwide continuum, in which barriers are usually ill defined and are variable in time and space, giving ample time for the mixing of faunae of different geographic origin. The spreading and mixing of hydromedusae species is favoured by the presence in the life cycle of a bottom living stage that propagates asexually. The long lived hydroid that often grows on ship hulls, turtle shells, natural and man-made rafts of all sorts and forms large colonies by vegetative growth, may bud off medusae during a long time, seeding them over a wide area of the ocean. Some such species widely distributed passively with the interference of vegetative reproduction in the hydroid or medusoid stages are Clytia cylindrica (or C. attenuata; Clytia is the hydroid of Phialidium), Obelia spp., Cytaeis tetrastyla, Bougainvillia platygaster.

Accordingly we disregard geographic distribution of hydromedusae and try to find out whether ecological distribution shows clear patterns and where the causes that determine geographic distribution are related to environmental parameters like the proximity of a substratum. As mentioned (Vannucci \& Navas, 1973a), the water mass is here considered as the conservative environmental unit while the species is taken as the biological unit. The sampling design during the IIOE was far from satisfactory for this purpose because it was not random in space, depth or time, it did not cover the whole Indian Ocean and many samples were taken with open nets rather than with closing nets manipulated according to the hydrographic structure of the water column at the point of sampling. Nevertheless, the wealth of data and the large number of stratified samples allow for a tentative interpretation.

\section{Conclusions}

1. Deep and intermediate water hydromedusae. This is a group of species that tolerate water colder than $2^{\circ} \mathrm{C}$ and 
salinity lower than $35 \%$; deep waters are usually poorer in oxygen content and in the Arabian Sea they may be very poor. Only a few samples were taken in deep waters but a large number comes from intermediate water masses. Most deep and intermediate water species have a temperature controlled distribution, but some have not been found so far in the Antarctic. This indicates that there is a group of Antarctic species that are tolerant of great depths and sink at the Antarctic and sub-Antarctic convergences, then spread north via AIW and ABW and later diffuse to other cold water masses. There are other species that are depth dependant and more often found in deep layers, suggesting that some factor other than temperature limits their distribution or that they are unable to compete with other species at higher levels. Thus many deep water species are euryhaline, eurybathic, eurythermal and tolerant of low oxygen, such as: Solmissus marshalli, Tetrorchis erythrogaster, Aequorea pensilis, Protiara tropica, Merga violacea, Zanclea orientalis, Vannuccia forbesi. These species are only rarely found over shallow depths. They cannot compete with more successful surface or subsurface species, which are unable to live at great depths because of one or another of their stenotopic requirements.

The following are deep water species not yet recorded in the Antarctic Ocean: Merga reesi, Aglantha elata, Tetrorchis erythrogaster.

Deep water species usually have a wide but scattered distribution and are not abundant numerically nor frequently found. It is not yet clear whether the deep water fauna of medusae is distinct from the Antarctic fauna or whether it has not yet been recorded in the Antarctic because of scarce sampling and infrequent use of small meshed nets. Some eurythermic and eurybathic deep water species are not restricted to cold deep water such as Pantachogon haeckeli and Euphysora furcata. .

The Antarctic fauna, similarly to the deep water has preference for low temperature. It spreads north with the water sinking at the convergences and although AIW cannot be traced as such north of $10^{\circ} \mathrm{S}$ latitude in the Indian Ocean, many of the species it carries are often found throughout the Indian Ocean far north in the Arabian Sea and in the Bay of Bengal intermediate and subsurface water. Those that tolerate relatively higher temperature occur in upwelling areas. Also in this case, it is not yet clear whether the population found north of $10^{\circ} \mathrm{S}$ latitude are separate populations or whether mixing goes on with the southern populations. The Antarctic species found to sink at the Antarctic and sub-Antarctic convergences are usually found also in the upper layers of the Antarctic Ocean.

The following species were found in Antarctic waters (Navas- Pereira, in press) and also north of the subtropical convergence: Botrynema brucei, Halicreas minimum, Colobonema sericeum, Crossota brunnea, C. alba, Pantachogon haeckeli, Cunina duplicata, Solmissus marshalli, Halitrephes maasi, Aegina citrea, Aeginura grimaldii, Pegantha clara, $P$. martagon, $P$. laevis and Haliscera racovitzae. All of them were found to be cold limited or cold tolerant species, but some are not restricted to very cold nor to deep waters. Thus Solmissus marshalli and Cunina duplicata were found in upwelling waters in the eastern Bay of Bengal, the western Arabian Sea and in the central Indian Ocean near the Equator.Pegantha martagon was found also in surface waters all over the Indian Ocean. Each of the Antarctic species has a different pattern of distribution northwards. A detailed study of the behaviour and pattern of distribution of these species is in preparation (Navas-Pereira, in press). However, the exclusively Antarctic and sub-Antarctic species were not taken in temperature higher than about $12^{\circ} \mathrm{C}$ and most of them are tolerant of low dissolved oxygen content, but not lower than about $1.5 \mathrm{ml} / 1$. Of those encountered during the IIOE, only Pantachogon haeckeli, Crossota brunnea and Botrynema brucei appear to have relatively high oxygen requirements.

Sinking of Antarctic species at the subtropical convergence is very clear and some species like Crossota brunnea are not found north of the northern boundary of the AIW.

The presence of deep water or Antarctic species in relatively shallow depths in the Arabian Sea and in the Bay of Bengal is noteworthy.

2. We have earlier (Vannucci \& Navas, 1973a) indicated that from the point of view of distributional patterns a group of Indian Ocean Central Water species may be recognized and is represented by an assemblage of species from subsurface to intermediate depths usuarly concentrated at the boundary between water masses. They spread horizontally from the subtropical convergence to the Arabian Sea and to the Bay of Bengal excluding coastal areas. This group includes those species that prefer or tolerate temperature as high as about $19^{\circ} \mathrm{C}$ and salinity between 34.5 to $36.0 \%$. In the Arabian Sea many species of this group are excluded by low oxygen content, while in the Bay of Bengal they are excluded by low salinity, not higher than 34.1 to $35.0 \%$ (Table 1). The species of this group (Table 2) tend to have a wide geographic distribution, Sibogita geometrica, Amphogona apicata are examples of this group.

3. The Bay of Bengal has a peculiar association of species that prefer or tolerate a combination of high temperature and low salinity over a wide area in the surface layer. Furthermore, salinity decreases from south to north and there is a complicated circulation. The surface layer does not extend below $150 \mathrm{~m}$ depth, thus relatively cold waters (temperature lower than $19^{\circ} \mathrm{C}$ ) with salinity lower than $35.0 \%$ are found near surface. Neritic species are found widely distributed in the surface in BBSW, even far from land and the continental shelf and many are hitherto unrecorded from the other parts of the Indian Ocean. These specimens may be found as far as current velocity and their longevity will take them. The species mentioned below are very commonly found in BBSW, while those that so far were found nowhere else in the Indian Ocean are indicated in Table 2. The most common species in BBSW are Anthomedusae and Leptomedusae all of which have a hydroid in their life cycle. The cosmopolitan Liriope tetraphylla and Cunina tenella are those most frequently encountered and are holoplanktonic. Among the species that have vegetative reproduction of the medusa, Bougainvillia platygaster is the most frequent. This list refers to BBSW in the oceanic part of the Bay of Bengal since coastal areas were not at all or only very poorly sampled during the IIOE. It is our belief that when coastal waters will be studied throughout the Indian Ocean and especially in the low salinity regions, also waters near estuaries, coastal lagoons, river deltas and similar areas, 
many of the species that were taken during the IIOE only in the Bay of Bengal will be found also in other parts of the Indian Ocean, including the Arabian Sea (Vannucci \& Santhakumari, 1971).

4. In the Arabian Sea also there is a peculiar association of species, given the combination of high temperature and salinity usually higher than $35.5 \%$ in the surface $150 \mathrm{~m}$ layer (ASSW), and temperature lower than $19^{\circ} \mathrm{C}$ and salinity always higher than $35.0 \%$ at subsurface and intermediate depths. The Arabian Sea has also a very peculiar pattern of oxygen distribution with an extremely low or even oxygen free layer at shallow depths. The oxygen minimum layer actually rises to the surface at times, off the Indian coast. Nevertheless, many species of medusae that might have been thought of as having high oxygen requirements due to their habits of active predation, were found to be living in this oxygen depleted environment. Some of the Bay of Bengal species are found in coastal and estuarine areas of the Arabian Sea, such as Pandeopsis scutigera, Phialucium condensum, Helgicirrha medusifera (Vannucci \& Santhakumari, 1971). It is noteworthy that these species have a restricted distribution in the Arabian Sea, while they are spread over a wide area in the Bay of Bengal, by BBSW. The following are the species more frequently found in ASSW and ASSSW: Solmundella bitentaculata, Cunina octonaria. Furthermore, Aglaura hemistoma is characteristically relatively more abundant than Liriope tetraphylla.

Summing up, among the dominant species, Liriope tetraphylla, Rhopalonema velatum and Cunina tenella characterize the Bay of Bengal waters, while a preponderance of Aglaura hemistoma and Solmundella bitentaculata characterize the Arabian Sea.

5. Finally another group of species may be recognized; it pertains to the Equatorial Indian Ocean System. The distribution of these species is centred in the surface and thin layer of the IOEW mass that has comparatively low salinity, from 34.0 to $35.0 \%$; high temperature throughout the year, from 26.0 to $27.0^{\circ} \mathrm{C}$ and high dissolved oxygen content ranging from 3.40 to $7.46 \mathrm{ml} / 1$. From the Equatorial Water Mass, species spread to adjoining waters where conditions are favourable. The system of equatorial currents and countercurrents maintains the species in the belt of warm surface waters near the Equator. Such are, for instance: Euphysora furcata, Bougainvillia fulva, $B$. platygaster, Laodicea fijiana, Eirene viridula, Rhopalonema velatum, Pegantha clara, P. laevis, Cunina octonaria and Cunina peregrina.

\section{Resumo}

Esta análise da distribuição e abundância de hidromedusas é complementar ao relatório sobre a ecologia das hidromedusas do Oceano Índico, baseado no material coletado durante a Expedição Internacional do Oceano Índico. A distribuiçāo e abundância sāo consideradas como a expressāo ecológica da variabilidade espacial e temporal das espécies. O objetivo era identificar a assinatura biológica de massas d'água subsuperficiais, que nâo podem ser identificadas através de técnicas de sensoriamento remoto. Espécies selecionadas foram consideradas como unidades biológicas, e as massas d'água, definidas pelos seus diagramas T-S e T-O2, como unidades abióticas; em conjunto, definem os diferentes ecossistemas do Oceano Índico.

Cerca de 45.000 exémplares de hidromedusas coletados em 480 Estaçōes foram separados de 900 amostras de plâncton, sendo todos contados e examinados. Diversos arrastos, principalmente estratificados, foram efetuados com redes de fechamento, mas nem todos continham hidromedusas. A distribuição de cada espécie foi estudada em relação a salinidade, temperatura e teor de oxigênio dissolvido na água; os limites de tolerância ecológica e preferências foram definidos pelas características ambientais das camadas amostradas pelas redes,sendo dadas para cada espécie. Essas espécies podem ser agrupadas da seguinte forma: 1. Espécies de águas profundas, preferindo baixas temperaturas, geralmente euritópicas; 2. Espécies antárticas, tolerando baixas temperaturas, geralmente estenotérmicas, preferindo baixa salinidade; 3 . Espécies da Água Central do Oceano Índico, preferindo temperaturas inferiores a $19^{\circ} \mathrm{C}$ e salinidade nảo muito superior a $35 \%$, geralmente encontradas em profundidades subsuperficiais ou intermediárias, podendo se dispersar para o Mar Arábico ou para a Baía de Bengala, nas camadas superficiais; 4. Espécies do Sistema Equatorial do Oceano Indico, tolerando temperaturas elevadas, preferem geralmente salinidade relativamente baixa, temperatura e teor de oxigênio elevados; 5. Espécies da Água Superficial da Báa de Bengala, encontradas nas camadas superficiais da Baía, preferindo baixa salinidade, temperatura e teor de oxigênio elevados; 6. Espécies da Água Superficial do Mar Arábico, preferindo alta salinidade e alta temperatura; 7. Espécies raras. Foram descritos alguns imigrantes do Mar Mediterrâneo, e verificou-se que muitas espécies toleram teores de oxigênio dissolvido tão baixos quanto $0.2 \mathrm{ml} / 1$. Muitos indivíduos de diversas espécies costumam aglomerar-se em camadas de discontinuidade entre massas d'água.

\section{References}

ANONYMOUS. 1963-1965. U.S. Program in Biology: International Indian Ocean Expedition Final Cruise Report, "Anton Bruun" Cruises A-X, Woods Hole Oceanographic Institution.

BARY, B. McK. 1963a. Distribution of Atlantic pelagic organisms in relation to surface water bodies. Spec. Publs R. Soc. Can., (5):51-67.

1963b. Temperature, salinity and plankton in the eastern North Atlantic and coastal waters of Britain, 1957. II. The relationships between species and water bodies. J. Fish. Res. Bd Can., 20:1031-1065.

BIGELOW, H. B. $1909 . \quad$ Rep. Sci. Res. Exped. Eastern Tropical Pacific U.S. Fish. Comm. Steamer "Albatross", 1904-1905. XVI. Medusae. Mem. Mus. comp. Zool. Harv., 37:1-243, 48 pls. 
BIGELOW, H. B. 1940. Medusae of the Templeton Crocker and Eastrern Pacific Zaca Expeditions, 1936-1938. Zoologia, N. Y., 25:281-321.

BROWNE, E. T. 1916. Medusae from the Indian Ocean. Trans. Linn. Soc. Lond. (Zool.), 17:169-210.

von BUDDENBROCK, W. 1952. Vergleichende Physiologie, vol. I, Sinnesphysiologie. Basel, Birkenhauser, 504 p.

ECKART-SCHMIDT, H. 1973. Die Hydromedusen (Hydrozoa: Coelenterata) des Roten Meeres und seiner angrenzenden Gebiete. Meteor Forschergebnd. (15):1-35.

FRASER, J. H., 1969. Experimental feeding of some Medusae and Chaetognatha. J. Fish. Res. Bd Can., 26:1743-1762.

GALLAGHER, J. F. 1966. The variability of water masses in the Indian Ocean. NODC Publ. G-11. Washington, D.C. : 1-74.

GANAPATI, P. N. \& NAGABHUSHANAM, R. 1958. Seasonal distribution of the Hydromedusae off the Visakhapatnam coast. Andhra Univ. Mem. Oceanogr., 62(2):91-99.

GAUSE, G. F. 1934. The struggle for existence. Baltimore, Williams \& Wilkins.

GOY, J. 1979. Méduses. Résult. scient. Camp. Calypso, (11):263-296.

HAECKEL, E. 1879. Das System der Medusen. Erster Theil einer Monographie der Medusen. Jena, 360 p., 20 pls.

HARGITT, C. W. 1902. Notes on a few medusae new to Woods Hole. Biol. Bull. mar. biol. Lab., Woods Hole, 4:13-23.

HUTCHINSON, G. E. 1959. Homage to Santa Rosalia or why are there so many kinds of animals. Amer. naturalist., 93:145-159.

KRAMP, P. L 1928. Papers from Dr. Th. Mortensen's Pacific Expedition 1914-16. XIIII. Hydromedusae. I. Anthomedusae. Vidensk. Meddr dansk naturh. Foren., 85:27-64.

1942. Medusae. The "Godthaab" Expedition 1928. Meddr. Grønland., 81:1-168.

1953. Hydromedusae. Scient. Rep. Gt Barrier Reef Exped., 6:259-322.

1955. The medusae of the tropical west coast of Africa. Atlantide Rep., 3:239-324.

1957. Hydromedusae of the Discovery collections. Discovery Rep., 29:1-128.
KRAMP, P. L. 1959a. The Hydromedusae of the Atlantic Ocean and adjacent waters. Dana Rep., 46:1-283.

1959b. Some new and little-known IndoPacific Medusae. Vidensk. Meddr dansk naturh. Foren., 121:223-259.

1961a. Synopsis of the Medusae of the World. J. mar. biol. Ass. U. K., 40:1-469.

1961b. Some Medusae from northern Australia. Trans. R. Soc. S. Aust., 85:197-205.

1962. Medusae of Vietnam. Vidensk. Meddr dansk naturh. Foren., 124:305-366.

1965. The Hydromedusae of the Pacific and Indian Oceans. Dana Rep., 63:1-161.

1968. The Hydromedusae of the Pacific and Indian Oceans. Sections II and III. Dana Rep., 72:1-200.

MAAS, O. 1905. Die Craspedoten Medusen der Siboga Expedition. Siboga Exped., (10):1-85.

MARGALEF, R. 1957. Variación local e interanual en la secuencia de las poblaciones de fitoplancton de red en las aguas superficiales de la costa mediterránea española. Investigación pesq., Barcelona, 9:65-95.

1968. Perspectives in ecological theory. London. University of Chicago Press, $111 \mathrm{p}$.

Omega. 951 p.

1982. Ecología. Barcelona, Ediciones

MAYER, A. G. 1900. Some Medusae from the Tortugas, Florida. Bull. Mus. comp. Zool. Harv., 37:13-82.

1910. Medusae of the World. Publs Carnegie Instn, (109): 3v.

MENON, M. G. K. 1932. The Hydromedusae of Madras. Bull. Madras Govt. Mus. N. S. Nat. Hist. Sect., 3:1-32.

NAIR, K. K. 1951. Medusae of the Trivaindrum coast. Part I. Systematics. Bull. Res. Inst. Univ. Travancore, Ser. C., Nat. Sci., 2:47-75.

NAUMOV, D.V. 1956. Medusae in the far-eastern waters of the Soviet Union. Trudy probl. temat. Soveshch. zool. Inst.(6):34-41. (In Russian).

NAVAS, D. 1969. Halistaura bruuni sp. nov. (Leptomedusae, Mitrocomidae) with notes on its distribution and ecology. Mar. Biol., 2(4):307-310.

1971. New records of Hydromedusae from the Indian Ocean. Contrções Inst. oceanogr. Univ. S Paulo, ser. Oceanogr. biol., (22):1-33. 
NAVAS-PEREIRA, D. 1980. Hydromedusae of the Bay of Sepetiba (Rio de Janeiro, Brazil). Revta bras. Biol., 40(4):817-824.

1981. Distribuição das hidromedusas (Cnidaria, Hydrozoa) na regiāo da plataforma continental do Rio Grande do Sul. In: SEMINÁRIOS DE BIOLOGIA MARINHA, Sāo Paulo, 1980. Rio de Janeiro, Academia Brasileira de Ciências. p.221-276.

1984a. On the morphological variability of Phialucium canolinae (Mayer, 1900) (Leptomedusae, Phialuciidae). Dusenia, 14(2):5153.

1984b. New record of budding in Zanclea costata (Anthomedusae, Zancleidae). Dusenia, 14(3):89-93.

medusae and water masses.

(in press). Antarctic Hydro-

PETERSEN, K. W. \& VANNUCCI, M. 1960. The life cycle of Koellikerina fasciculata (Anthomedusae, Bougainvillidae). Pubbl. Staz. zool. Napoli, 31:473492.

SCHMIDT-NIELSEN, K. 1990. Animal physiology: adaptation and environment. 4th. ed. Cambridge, Cambridge University Press. 602p.

VANHÖFFEN, E. 1913. Die Craspedoten Medusen des "Vettor Pisani". Zoologica, Stuttgart, 67:1-34.

VANNUCCI, M. 1957. On Brazilian Hydromedusae and their distribution in relation to different water masses. Bolm Inst. oceanogr., S Paulo, 8:23-109.

1960. On the young stage of Eucheilota duodecimalis (Leptomedusae). Anais Acad. bras. Ciênc., 32:395-397.

1963. On the ecology of Brazilian medusae at $25^{\circ}$ Lat S. Bolm Inst. oceanogr., S Paulo, 13:143-184.
VANNUCCI, M. 1966. Total net plankton volume and Hydromedusae from fixed stations in the Gulf of Naples. In: Barnes, H., ed. Some contemporary studies in marine science. London, Allen \& Unwin, p. 675-697.

\& NAVAS, D. 1973a. Distribution of Hydromedusae in the Indian Ocean. In: Zeitschel, B., ed. The biology of the Indian Ocean. Berlin, Springer-Verlag. 549 p.

1973b. On the ecology of Indian Ocean Hydromedusae. IOBC Handbook 5:1-54.

VANNUCCI, M. \& SANTHAKUMARI, V. 1971. New records of Hydromedusae from the shelf area off the Kerala coast. J. mar. biol. Ass. India, $11(1,2): 40-43$.

; SANTHAKUMARI, V. \& SANTOS, E. P. dos 1970 . The ecology of Hydromedusae from the Cochin area. Mar. Biol., 7:49-58.

\& SOARES-MOREIRA, M. G. B. 1966. Some Hydromedusae from the Gulf of Naples, with description of a new genus and species. Pubbl. Staz. zool. Napoli, 35:7-12.

VINOGRADOV, M. E. \& VORONINA, N. M. 1962. Influence of the oxygen deficit in the distribution of plankton in the Arabian Sea. Deep-Sea Res., 9:523530.

VOLTERRA, V. 1926. Variazioni e fluttuazioni del numero d'individui di specie animali conviventi. Memorie Accad. Lincei, Roma, 2:31-113.

(Received 08-Jan-91; accepted 13-Jun-91) 